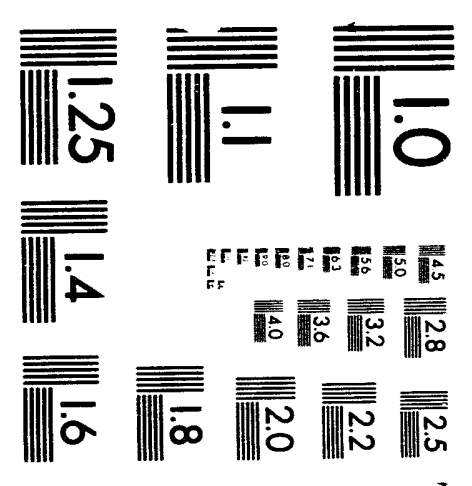



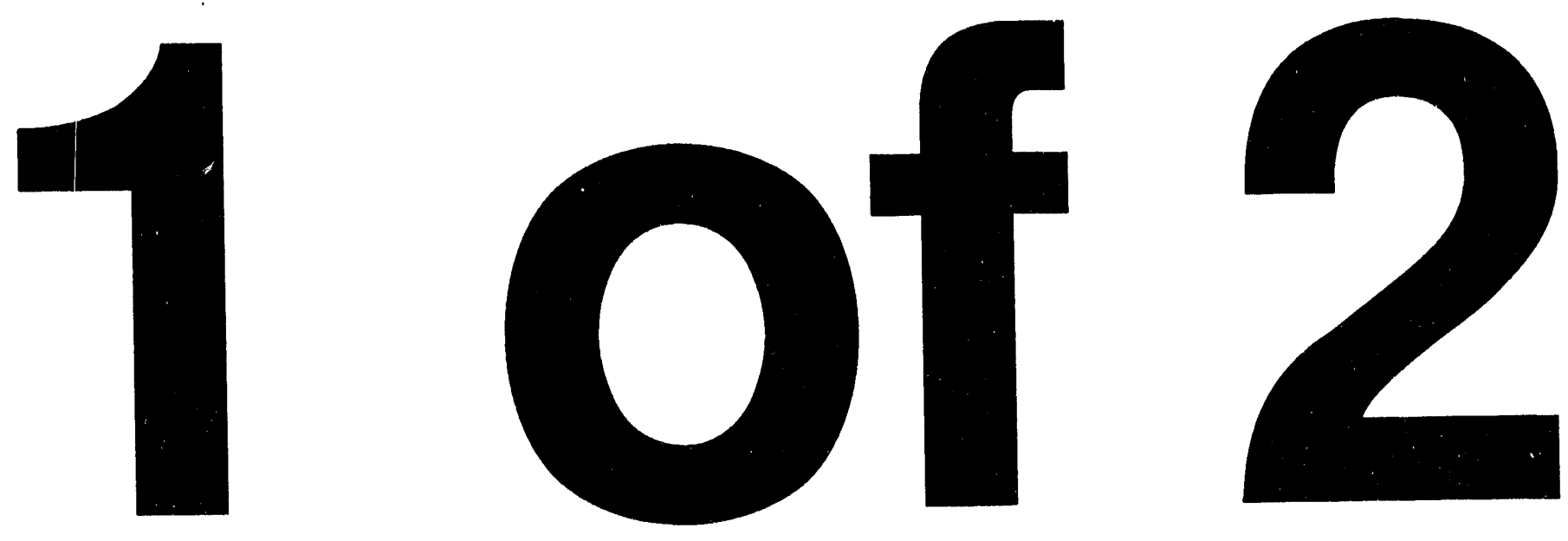


\section{Class I Overview of Cultural Resources for the Western Area Power Administratior. Salt Lake City Area Integrated Projects Electric Power Marketing Environmental Impact Statement}

by K.L. Moeller, L.M. Malinowski, J.F. Hoffecker, D.A. Walitschek, L. Shogren, J.E. Mathews, and B.T. Verhaaren

Environmental Assessment Division,

Argonne National Laboratory, 9700 South Cass Avenue, Argonne, Illinois 60439

November 1993

Work sponsored by the United States Department of Energy, Western Area Power Administration 


\section{CONTENTS}

ACKNOWLEDGMENTS $\ldots \ldots \ldots \ldots \ldots \ldots \ldots \ldots \ldots \ldots$ vii

NOTATION $\ldots \ldots \ldots \ldots \ldots \ldots \ldots \ldots \ldots \ldots \ldots \ldots \ldots \ldots \ldots \ldots$ viii

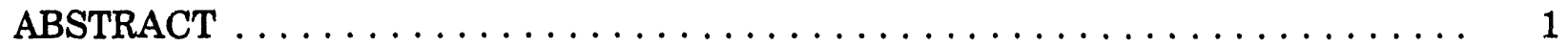

1 INTRODUCTION $\ldots \ldots \ldots \ldots \ldots \ldots \ldots \ldots \ldots \ldots \ldots \ldots \ldots \ldots$

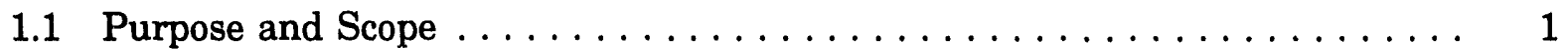

1.2 Study Area . . . . . . . . . . . . . . . . . . . . . . . . 2

1.3 Collection and Analysis of Data $\ldots \ldots \ldots \ldots \ldots \ldots \ldots \ldots \ldots \ldots$

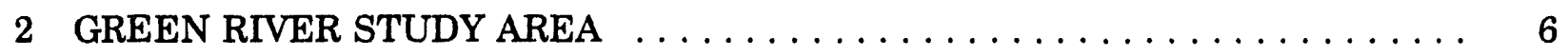

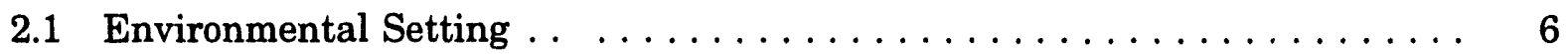

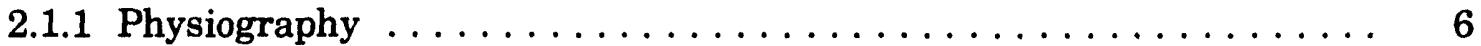

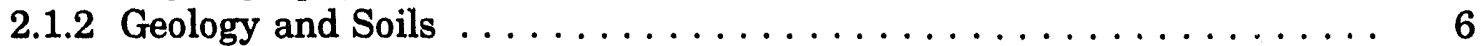

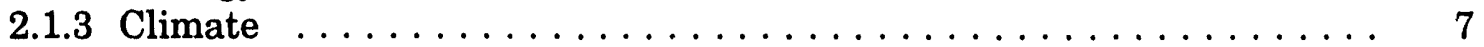

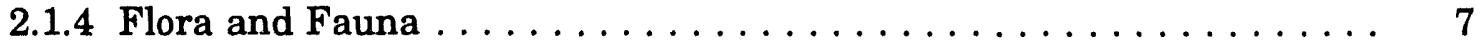

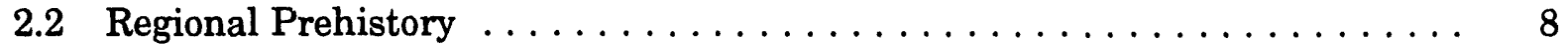

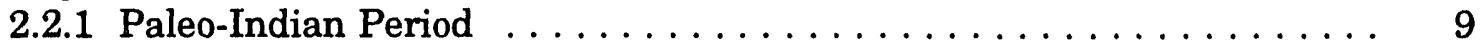

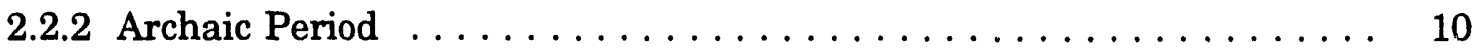

2.2.3 Late Prehistoric Period . . . . . . . . . . . . . . . . . . . . . 11

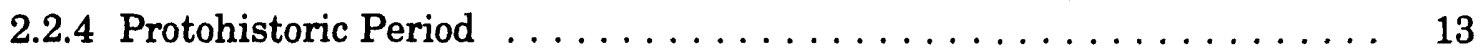

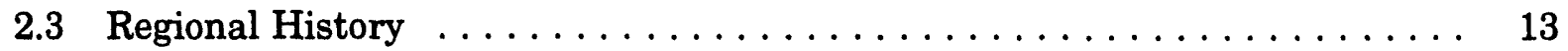

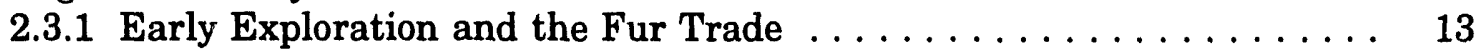

2.3.2 Westward Trails and River Ferries . . . . . . . . . . . . . . . . 15

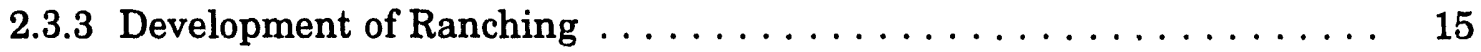

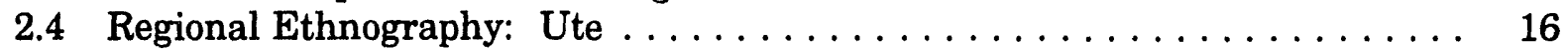

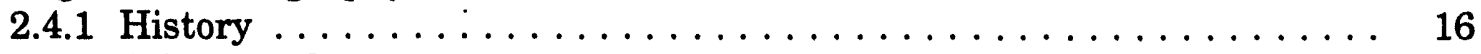

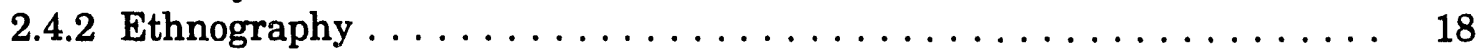

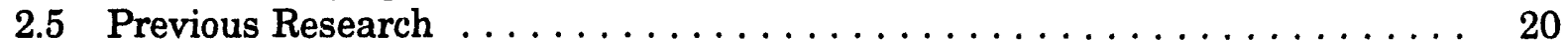

2.5.1 Reach 1: Flaming Gorge Dam to the Yampa River Confluence . . . . . 21

2.5.2 Reach 2: Yampa River Confluence to Cub Creek . . . . . . . . . . . 39

2.6 Recorded Sites . . . . . . . . . . . . . . . . . . . . . . . 39

2.6.1 Reach 1: Flaming Gorge Dam to the Yampa River Confluence . . . . . 51

2.6.2 Reach 2: Yampa River Confluence to Cub Creek . . . . . . . . . . . 53

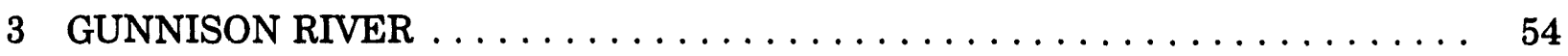

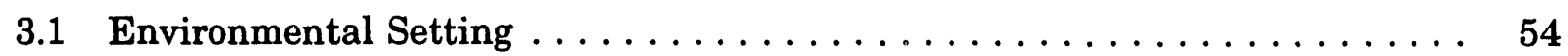

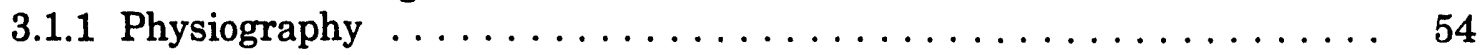

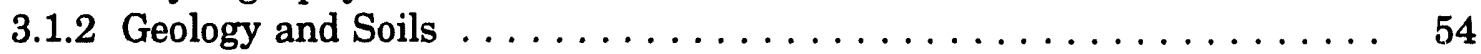

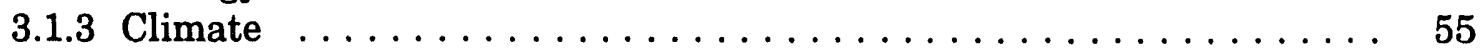

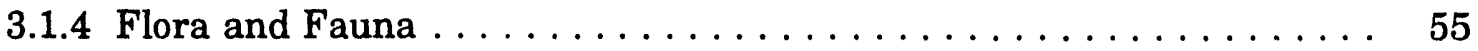




\section{CONTENTS (Cont.)}

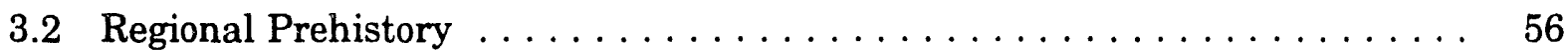

3.2.1 Paleo-Indian Period $\ldots \ldots \ldots \ldots \ldots \ldots \ldots \ldots \ldots \ldots \ldots \ldots \ldots \ldots \ldots \ldots \ldots \ldots$

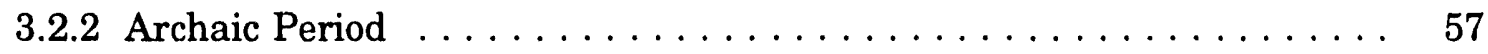

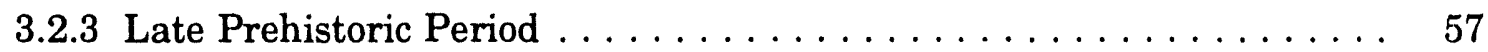

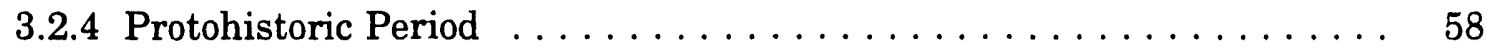

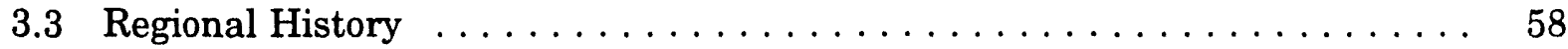

3.3.1 Spanish Settlement and Exploration ................. 58

3.3.2 Euro-American Trappers and Fur Traders $\ldots \ldots \ldots \ldots \ldots \ldots \ldots .59$

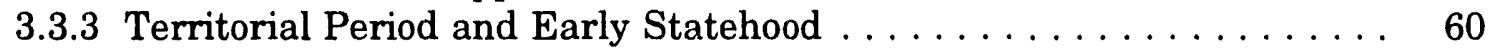

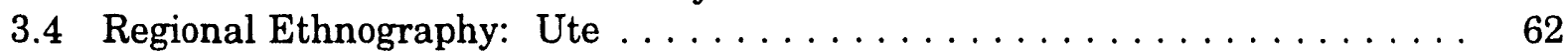

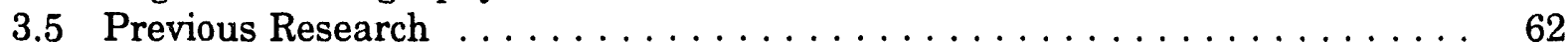

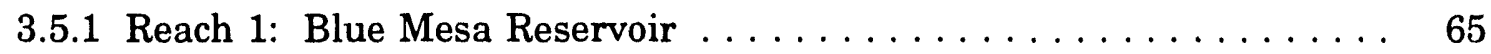

3.5.2 Reach 2: Blue Mesa Dam to Morrow Point Dam .......... 65

3.5.3 Reach 3: Morrow Point Dam to Crystal Dam ............... 65

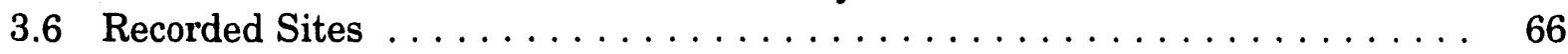

3.6.1 Reach 1: Blue Mesa Reservoir ................... 69

3.6.2 Reach 2: Blue Mesa Dam to Morrow Point Dam ........... 82

3.6.3 Reach 3: Morrow Point Dam to Crystal Dam ............... 84

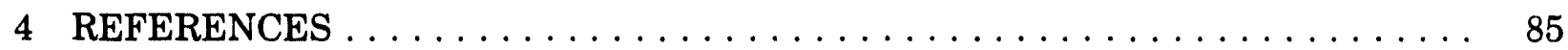

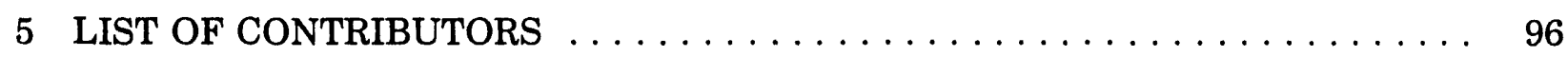

APPENDIX: Known Site Disturbance within the Study Area $\ldots \ldots \ldots \ldots \ldots . \quad 97$

\section{FIGURES}

1 Dams Potentially Affected by Western's Power Marketing Programs . . . . . . . 3

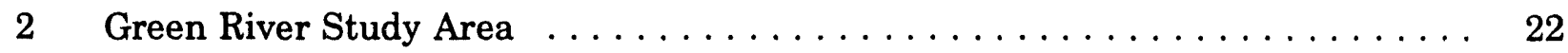

3 Previous Archaeological Surveys: Dutch John ................. 27

4 Previous Archaeological Surveys: Goslin Mountain $\ldots \ldots \ldots \ldots \ldots \ldots \ldots$

$5 \quad$ Previous Archaeological Surveys: Clay Basin $\ldots \ldots \ldots \ldots \ldots \ldots \ldots \ldots 29$

6 Previous Archaeological Surveys: Warren Draw $\ldots \ldots \ldots \ldots \ldots \ldots \ldots \ldots$

$7 \quad$ Previous Archaeological Surveys: Swallow Canyon $\ldots \ldots \ldots \ldots \ldots \ldots \ldots$

8 Previous Archaeological Surveys: Lodore School $\ldots \ldots \ldots \ldots \ldots \ldots \ldots \ldots$

9 Previous Archaeological Surveys: Canyon of Lodore North $\ldots \ldots \ldots \ldots \ldots$ 


\section{FIGURES (Cont.)}

10 Previous Archaeological Surveys: Canyon of Lodore South $\ldots \ldots \ldots \ldots \ldots .34$

11 Previous Archaeological Surveys: Jones Hole $\ldots \ldots \ldots \ldots \ldots \ldots \ldots \ldots . . \ldots \ldots$

12 Previous Archaeological Surveys: Island Park $\ldots \ldots \ldots \ldots \ldots \ldots \ldots \ldots$

13 Previous Archaeological Surveys: Upper Half of Split Mountain and Dinosaur Quarry Area $\ldots \ldots \ldots \ldots \ldots \ldots \ldots \ldots \ldots \ldots \ldots \ldots$

14 Previous Archaeological Surveys: Lower Half of Split Mountain and Dinosaur Quarry Area $\ldots \ldots \ldots \ldots \ldots \ldots \ldots \ldots \ldots \ldots \ldots$

15 Gunnison River Study Area $\ldots \ldots \ldots \ldots \ldots \ldots \ldots \ldots \ldots \ldots \ldots \ldots$

16 Previous Archaeological Surveys: Big Mesa $\ldots \ldots \ldots \ldots \ldots \ldots \ldots \ldots 66$

17 Previous Archaeological Surveys: Carpenter Ridge $\ldots \ldots \ldots \ldots \ldots \ldots \ldots .67$

18 Previous Archaeological Surveys: Sapinero $\ldots \ldots \ldots \ldots \ldots \ldots \ldots \ldots$

19 Previous Archaeological Surveys: Curecanti Needle . . . . . . . . . . . . 69

20 Previous Archaeological Surveys: Cimarron and Cathedral Peak ........ 70

\section{TABLES}

1 Native American Tribes in the Green River Study Area $\ldots \ldots \ldots \ldots \ldots .17$

2 Previous Archaeological Surveys in the Green River Study Area $\ldots . \ldots \ldots \ldots 23$

3 Green River: Recorded Sites in Reach $1 \ldots \ldots \ldots \ldots \ldots \ldots \ldots \ldots, 40$

4 Green River: Recorded Sites in Reach $2 \ldots \ldots \ldots \ldots \ldots \ldots \ldots \ldots \ldots$. . . . . . 47

5 Previous Archaeological Surveys in the Gunnison River Study Area . . . . . 63

6 Gunnison River: Recorded Sites in Reach $1 \ldots \ldots \ldots \ldots \ldots \ldots \ldots$

7 Gunnison River: Recorded Sites in Reach $2 \ldots \ldots \ldots \ldots \ldots \ldots \ldots$

A.1 Green River: Site Disturbance in Reach 1, Flaming Gorge Dam to the Yampa River Confluence $\ldots \ldots \ldots \ldots \ldots \ldots \ldots \ldots \ldots . \ldots 9$

A.2 Green River: Site Disturbance in Reach 2, Yampa River Confluence to Cub Creek . . . . . . . . . . . . . . . . . . . . . . . . . . . . . . . . . . 104 


\section{TABLES (Cont.)}

A.3 Gunnison River: Site Disturbance in Reach 1, Blue Mesa Reservoir . . . . . . . 107

A.4 Gunnison River: Site Disturbance in Reach 2, Blue Mesa Dam to Morrow Point Dam . . . . . . . . . . . . . . . . . . . . . . . 113 


\section{ACKNOWLEDGMENTS}

The Class I analysis of cultural resources reported here was accomplished with the help of several agencies. We would like to thank the following people for their assistance (and for their patience). Margaret Van Ness, Mary Sullivan, and Jennifer Barnier from the Colorado Historical Society in Denver, Colorado, were a tremendous help on the Colorado data for both the Gunnison River and the stretch of the Green River that runs through Moffat County, Colorado. Bruce Jones of the Midwest Archaeological Center, National Park Service (NPS) also provided valuable information on the Gunnison River within the Curecanti National Recreation Area. Tim Seaman and Lou Haecker of the Archaeological Records Management System (ARMS) at the Laboratory of Anthropology in Santa Fe, New Mexico, helped us track down the needed data on the Rio Grande, and Steve Lekson, Curator of Archaeology for the Museum of Indian Arts and Culture (also at the Laboratory of Anthropology), provided us with ethnographic data as well as archaeological background for the area in general. The Green River, which flows through Wyoming, Colorado, and Utah, proved to be the most challenging in terms of data collection. In Wyoming, Mary Hopkins, Sandra Shelley, and William Batterman at the State Historic Preservation Office (SHPO) in Laramie, Wyoming, helped with the initial file search and site data in Wyoming. Russ Tanner of the Bureau of Land Management (BLM) in the Green River Resource Area (Rock Springs, Wyoming) provided a great deal of assistance with map data and other background material. Dave Vlcek of the BLM in the Pinedale Resource Area and Lynn Harrell of the BLM in the Kemmerer Resource Area were also valuable sources of information for the area. Byron Loosle of Ashley National Forest in Vernal, Utah, also provided some map data for the area in Wyoming that is part of Ashley. The Colorado area, as mentioned previously, was covered by the Colorado Historical Society and also in part by James Truesdale, an NPS archaeologist at Dinosaur National Monument. Mr. Truesdale, along with Mr. Loosle and Blaine Phillips of the BLM (Vernal District), provided the bulk of the data needed for Utah. Evelyn Seelinger of the SHPO's office in Salt Lake City, Utah, had encouraged us to visit these other agencies first, and was then able to help us fill in data gaps we encountered, especially with data on specific sites. All of these people were essential in the data collection phase of this report. 


\section{NOTATION}

The following is a list of the acronyms, initialisms, and abbreviations (including units of measure) used in this document. Some acronyms used in tables only are defined in the respective tables.

\section{Acronyms, Initialisms, and Abbreviations}

$\begin{array}{ll}\text { ANL } & \text { Argonne National Laboratory } \\ \text { BLM } & \text { Bureau of Land Management } \\ \text { CFR } & \text { Code of Federal Regulations } \\ \text { EIS } & \text { environmental impact statement } \\ \text { MSL } & \text { mean sea level } \\ \text { NPS } & \text { National Park Service } \\ \text { NR } & \text { National Register (District) } \\ \text { NRHP } & \text { National Register of Historic Places } \\ \text { SHPO } & \text { State Historic Preservation Office or Officer } \\ \text { USFS } & \text { U.S. Forest Service } \\ \text { USGS } & \text { U.S. Geological Survey } \\ \text { Western } & \text { Western Area Power Administration }\end{array}$

\section{Units of Measure}

$\begin{array}{ll}\text { cfs } & \text { cubic foot (feet) per second } \\ { }^{\circ} \mathrm{F} & \text { degree(s) Fahrenheit } \\ \mathrm{ft} & \text { foot (feet) } \\ \mathrm{ft}^{2} & \text { square foot (feet) } \\ \text { in. } & \text { inch(es) } \\ \mathrm{mi} & \text { mile(s) } \\ \text { yd } & \text { yard(s) }\end{array}$




\title{
CLASS I OVERVIEW OF CULTURAL RESOURCES FOR THE WESTERN AREA POWER ADMINISTRATION SALT LAKE CITY AREA INTEGRATED PROJECTS ELECTRIC POWER MARKETING ENVIRONMENTAL IMPACT STATEMENT
}

by

\author{
K.L. Moeller, L.M. Malinowski, J.F. Hoffecker, D.A. Walitschek, \\ L. Shogren, J.E. Mathews, and B.T. Verhaaren
}

\begin{abstract}
Argonne National Laboratory conducted an inventory of known archaeological and historic sites in areas that could be affected by the hydropower operation alternatives under analysis in the power marketing environmental impact statement for the Western Area Power Administration's Salt Lake City Area Integrated Projects. The study areas included portions of the Green River (Flaming Gorge Dam to Cub Creek) in Utah and Colorado and the Gunnison River (Blue Mesa Reservoir to Crystal Dam) in Colorado. All previous archaeological surveys and previously recorded prehistoric and historic sites, structures, and features were inventoried and plotted on maps (only survey area maps are included in this report). The surveys were classified by their level of intensity, and the sites were classified according to their age, type, and contents. These data (presented here in tabular form) permit a general assessment of the character and distribution of archaeological remains in the study areas, as well as an indication of the sampling basis for such an assessment. To provide an adequate context for the descriptions of the archaeological and historic sites, this report also presents overviews of the environmental setting and the regional prehistory, history, and ethnography for each study area.
\end{abstract}

\section{INTRODUCTION}

\subsection{PURPOSE AND SCOPE}

Argonne National Laboratory (ANL) is preparing an environmental impact statement (EIS) for the Western Area Power Administration (hereafter referred to as Western) to determine the potential effects on dam operations of changes in power marketing programs. The pattern of hydropower generation in Western's region may change as a result of flow restrictions that have been imposed in some areas. The EIS addresses the effects of the power marketing program on hydropower dam operations, which, in turn, could affect both dam reservoir margins and erosion of sediment downstream of dams; these effects could damage or destroy cultural resource sites located along the margins of the reservoirs, 
streams, and rivers. The following dams may be affected (Figure 1): Fontenelle Dam in Wyoming; Flaming Gorge and Deer Creek dams in Utah; the Aspinall Unit (Crystal, Morrow Point, and Blue Mesa dams) and Collbran Project (Upper Molina and Lower Molina dams) in Colorado; Glen Canyon Dam in Arizona; and Elephant Butte Dam in New Mexico.

The National Environmental Policy Act and various historic preservation laws require an assessment of effects on cultural resources as part of an EIS. This document presents the results of a "Class I" review, which examined existing information on cultural resources in the study area (Section 1.2).

Cultural resources include both archaeological sites (e.g., prehistoric rockshelters or campsites) and historic structures and features (e.g., historic buildings or trails) that are protected under the National Historic Preservation Act, Archeological Resources Protection Act, and other laws. Cultural resources also include traditional resources, such as sacred areas or traditional use areas, that are important to a community's practices and beliefs and are necessary to maintain the cultural identity of the community. Cultural resources that meet the eligibility criteria for the National Register of Historic Places (NRHP) - Title 36, Code of Federal Regulations, Part 60 (36 CFR 60) - are considered "significant" resources and must be taken into consideration during the planning of federal projects. Federal agencies are also required by the American Indian Religious Freedom Act to consider the effects of their actions on sites, areas, or other resources (e.g., sacred plants) that are of religious significance to Native Americans. Graves and burial grounds are protected by the Native American Graves Protection and Repatriation Act.

This Class I overview is primarily devoted to an inventory of known archaeological sites and historic structures and features. The inventory was compiled from reports, files, and maps obtained from appropriate State Historic Preservation Offices (SHPOs) and various federal agencies (Section 1.3). To properly evaluate the inventory, previous field surveys in the study area were reviewed and analyzed (Sections 2.5 and 3.5). A general interpretive framework is provided by reviews of the regional environmental setting, prehistory, and history (Sections 2.1, 2.2, 2.3, 3.1, 3.2, and 3.3). Specific sites, areas, and resources of religious significance to Native Americans were not inventoried for the Class I overview; potentially affected tribes will be formally consulted at a later stage in the EIS process. However, regional ethnography reviews are included here (Sections 2.4 and 3.4) to provide some general information on Native American groups in the study area.

\subsection{STUDY AREA}

The study areas examined in this Class I. report include the Green River between Flaming Gorge Dam and Cub Creek (Utah) and the Gunnison River between Blue Mesa Reservoir and Crystal Dam (Colorado). The selection of study areas was based on (1) the dam facilities that would be affected by Western's power marketing program, (2) the design and scope of the EIS, and (3) preliminary estimates of the areas that would be affected by the dam operations analyzed in the EIS. 


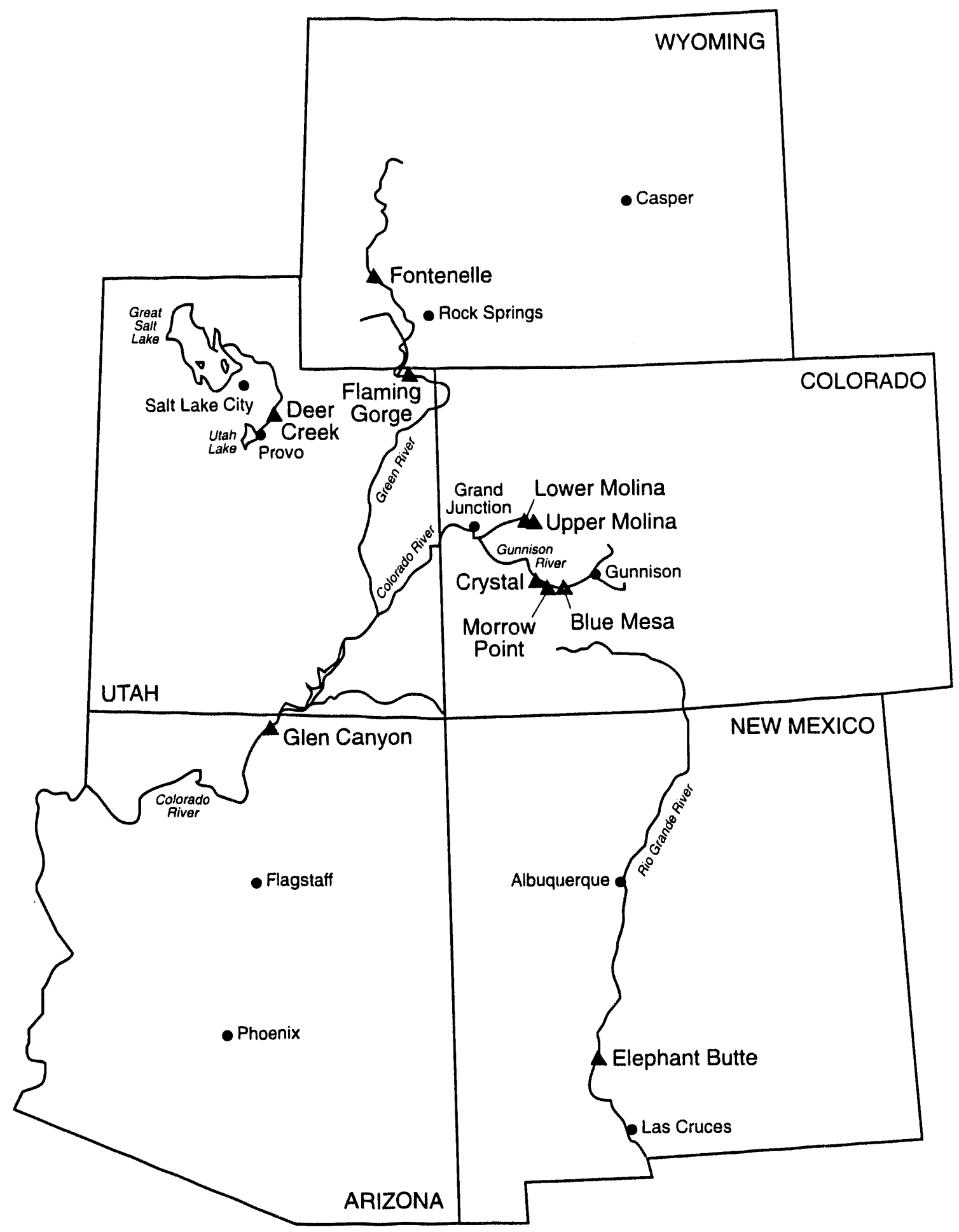

FIGURE 1 Dams Potentially Affected by Western's Power Marketing Programs (dams are indicated by triangles) 
The scope of the Western power marketing EIS had not been fully determined when this Class I overview began in August 1991. Since that time, several developments have occurred concerning the selection of dams being addressed in the EIS. As a result, this report does not discuss some of the dams listed above that may be affected by the proposed changes. Prior to August 1991, dams such as Deer Creek in Utah and the Collbran Project (Upper and Lower Molina) in Colorado were determined to be outside the sphere of Western's control with respect to water releases. They were therefore excluded from consideration in the EIS and were not included in this report. If these projects are reincorporated into the EIS, a Class I supplement will be issued to cover study areas tied to these facilities. In January 1992, Fontenelle and Elephant Butte dams were determined to be minor elements in Western's power marketing programs. Therefore, they are not analyzed as extensively as the Flaming Gorge, Glen Canyon, and Aspinall Unit dams in the EIS, and analyses of study areas related to Fontenelle and Elephant Butte are not included in this report.

The Glen Canyon Dam, Western's primary source of power (approximately $80 \%$ ), is treated extensively in the EIS, but is not included in this Class I overview. A separate EIS addressing the effects of Glen Canyon Dam operations is being prepared by the U.S. Bureau of Reclamation, concurrently with the Western power marketing EIS. A series of environmental studies, including an intensive archaeological survey (Fairley et al. 1991), have been undertaken to provide data and analyses for the Glen Canyon EIS. Thus, ANL is assessing the environmental effects of the power marketing program on Glen Canyon on the basis of the studies conducted for the Glen Canyon EIS.

The most problematic aspect of the Class I study was identifying the boundaries of areas containing cultural resources that could be affected by the Western power marketing

program. Although the affected area along reservoir margins can be predicted, the zone of influence downstream of the dams is difficult to estimate. On the basis of consultations with ANL hydrologists, a preliminary estimate of $50 \mathrm{mi}$ downstream of each dam was identified as the zone of potential effects for this study; this estimate was subsequently increased to $100 \mathrm{mi}$. However, the zone of potential effects on the Gunnison River was confined to a significantly shorter corridor by the presence of downstream dams and reservoirs. A minimum corridor width of $0.5 \mathrm{mi}$ from each river bank or reservoir margin, and a maximum width of $60 \mathrm{ft}$ above water level (as indicated on U.S. Geological Survey [USGS] topographic maps), was established. These study area boundaries are subject to revision as hydrological studies proceed for the EIS.

\subsection{COLLECTION AND ANALYSIS OF DATA}

This Class I overview is based on a review of existing literature and site records relevant to the study areas. Data were collected regarding all previous surveys and all previously recorded archaeological sites, historic structures, and features in the study area corridors. First, the SHPOs in Colorado, New Mexico, Utah, and Wyoming were contacted. In some cases (e.g., New Mexico), all necessary information was available in one location. However, in most cases, the SHPO referred ANL staff to other agency offices, such as the 
Bureau of Land Management (BLM), the U.S. Forest Service (USFS), and the National Park Service (NPS).

In September 1991, ANL staff visited agency offices to gather information from files, maps, and reports. The USGS topographic maps with plotted site locations were photocopied at each office from quadrangles of the appropriate study area. From these maps, sites determined to lie within the study area boundaries were recorded. Except for Utah, all the SHPOs had computerized records systems, and printouts of site information were available. Archaeological and historic site survey reports pertaining to the study area were located and photocopied, including reports of negative results (i.e., no sites were located within the area surveyed). Other reports containing regional background information were also photocopied. After the initial file search in September, all of the data were entered into a document control database and a site information database.

The survey reports were used to determine the proportion of the study area sampled to date and the level of sampling intensity. Areas surveyed were plotted (according to sampling intensity) against the study area corridors on USGS topographic maps. Illustrations based on these maps and tables summarizing the methodology and results of the surveys are presented in Sections 2.5 and 3.5. Maps, reports, and files obtained from the agencies were used to determine the location and type of all archaeological sites and historic structures and features recorded to date within the study areas. Figures illustrating the locations of sites are not included in this report, although information about each site is presented in tabular form and the topographic context of sites is discussed in general terms in the text. Information about sites presented here includes "significance" or NRHP status: some sites have been listed on the NRHP, or formally determined eligible for it, and many sites have been informally designated as "potentially eligible" or "not eligible" but have not received a formal determination by the appropriate SHPO and/or managing agency. These analyses of previous surveys and the distribution of recorded sites permits some general predictive statements about the probable contents of areas that have not been surveyed. 


\section{GREEN RIVER STUDY AREA}

\subsection{ENVIRONMENTAL SETTING}

\subsubsection{Physiography}

The Green River study area is situated in the Middle Rocky Mountains of northeastern Utah and northwestern Colorado. Elevations range from 4,759 ft above mean sea level (MSL) along the river bottoms, to over 9,000 $\mathrm{ft}$ MSL in the surrounding hills and mountains. The area is bounded on the west by the Uinta Mountains and Diamond Mountain Plateau and on the east by the Cold Spring and Douglas mountains and Yampa Plateau. Between the upper and lower boundaries of the study corridor (Flaming Gorge Dam and Cub Creek, respectively), the river alternately flows through steep-walled canyons and small basins or holes. At Flaming Gorge, the river winds through Red Canyon and then flows across a broad topographic depression (Browns Park). Below Browns Park, the river enters the Canyon of Lodore and subsequently flows through Whirlpool Canyon and Split Mountain Canyon. These canyons are separated by small basins, which include Echo Park, Island Park, and Rainbow Park.

\subsubsection{Geology and Soils}

The mountain ranges in the study area are composed of Precambrian formations surrounded by younger rock strata of Cambrian to Tertiary age (Blackwelder 1950; Day and Dibble 1963). Near Flaming Gorge Dam, the river cuts through the uplifted bedrock formations of the Uinta Mountains, creating a series of steep canyons (i.e., Flaming Gorge, Horseshoe Canyon, and Red Canyon). Rock strata ranging in age from Precambrian to Holocene are exposed in these canyons (Hansen 1975). Below Red Canyon, the valley broadens as the river winds through Browns Park. The floor of this elongated depression is composed of Miocene and Pliocene sandstone and conglomerate (Browns Park Formation) derived from the Uinta Mountains. Quaternary deposits (Pleistocene and Holocene) include terraces, tributary alluvium, and aeolian sediment (Hansen 1965:131-137 ${ }^{1}$ ). Hansen (1965:131-132) identified five Pleistocene terraces or bench gravels composed of poorly sorted pebbles and gravels (chiefly derived from the Precambrian formations) interbedded with lenses of sand and silt. The three oldest levels of bench gravels exhibit deep weathering profiles and apparently antedate the Wisconsin Glaciation. The two youngest levels are less than $20 \mathrm{ft}$ above the modern floodplain. At least one Holocene terrace (6 to $9 \mathrm{ft}$ ) composed of sand is aiso present in Little Hole and Browns Park. According to Eddy et al. (1982:12), the modern soil profile on this terrace is no more than 150 years old. Extensive alluvial deposits (primarily sand and silt) occur along tributary streams; remains of modern bison (Bison bison) recovered from these deposits also indicate Holocene age (Hansen 1965:133).

1 In the reference citations for this report, the number(s) following the colon indicates the page(s) from which the information was taken. 
Aeolian sand, derived from the modern floodplain and older alluvial deposits, has accumulated in many areas, forming active or stabilized dunes (Blackwelder 1950; Eddy et al. 1982). South of Browns Park, the river once again enters narrow canyons incised into uplifted bedrock of the eastern Uinta Range (Canyon of Lodore, Whirlpool Canyon, and Split Mountain Canyon) (Hansen 1975).

Soils near the river are generally classified as dry and deep without clear zonation (Upper Colorado Region State-Federal Interagency Group 1971). This type of soil primarily consists of a calcareous horizon 20 to 60 in. deep; it is loan y or clayey, well-drained, and moderately permeable (Wilson et al. 1968; Larralde and Nickens 1980:13).

\subsubsection{Climate}

The climate in the Green River study area is generally cool and dry. In Browns Park, mean January temperatures range from a low of $8^{\circ} \mathrm{F}$ to a high of $32^{\circ} \mathrm{F}$; mean July temperatures range from about $52^{\circ} \mathrm{F}$ to $84^{\circ} \mathrm{F}$. Temperature extremes are especially pronounced in Dinosaur National Monument, where winter lows may reach $-60^{\circ} \mathrm{F}$ and summer highs may exceed $100^{\circ} \mathrm{F}$. Annual precipitation is low, ranging between 8 and 15 in. (Eddy et al. 1982; Mehls 1985; Woodward-Clyde 1985).

\subsubsection{Flora and Fauna}

Much of the Green River study area supports a low shrub vegetation, which is generally quite sparse and usually covers no more than $20 \%$ of the ground surface (Drager and Ireland 1986:25); however, the river floodplains often support more dense plant cover (Hickman 1984). On upland surfaces, shadscale (Atriplex confertifolia) and sagebrush (Artemisia tridentata) predominate, although winterfat (Ceratoides lanata), prickly-pear cactus (Opuntia polyacantha), and rabbitbrush (Chrysothamnus viscidiflorus) also are common. On the floodplain, greasewood (Sarcobatus vermiculatus) and rabbitbrush predominate; willows (Salix spp.), narrowleaf cottonwood (Populus angustifolia), and various grasses also are present (Day and Dibble 1963). On higher slopes, the pinyon/juniper community is widespread; this community consists of Utah juniper (Juniperus osteosperma), Pinyon pine (Pinus edulis), and a sparse understory. At even higher elevations, mountain shrub vegetation is interspersed with stands of Ponderosa pine (Pinus ponderosa) and Douglas fir (Pseudotsuga menziesii).

Large mammals common in the region include pronghorn (Antilocapra americanus), mule deer (Odocoileus hemionus), elk (Cervus elaphus canadensis), and moose (Alces alces). Pronghorn, the most abundant of these today, apparently was extensively exploited by the prehistoric people of the area (Ostrogorsky and Plew 1981:6; Smith and Creasman 1987:2.8). Bison (Bison sp.) and sheep (Ovis sp.), especially bighorn sheep (Ovis canadensis), probably also were common in the past (Armitage et al. 1982; Harrell and McKern 1986; Smith and Creasman 1987:2.7). 
Small and medium mammals include cottontail (Sylvilagus spp.), white-tailed jackrabbit (Lepus townsendii), badger (Taxidea taxus), coyote (Canis latrans), long-tailed weasel (Mustela frenata), striped skunk (Mephitis mephitis), red fox (Vulpes vulpes), bobcat (Lynx rufus), mountain lion (Felis concolor), several taxa of rodents (Long 1965), as well as muskrat (Ondatra zibethicus), beaver (Castor canadensis), marten (Martes americana), porcupine (Erethizon dorsatum), otter (Lutra canadensis), and mink (Mustela vison). Many of these were exploited by prehistoric and early historic human populations (Lowie 1924:199; Steward 1938:33; Ostrogorsky and Plew 1981:6; Smith and Creasman 1987:2.8).

Common birds in the region include the sage grouse (Centrocercus urophasianus), which was hunted prehistorically (Armitage et al. 1982; Harrell and McKern 1986; Hoefer and Creasman 1986). Canyon walls are used for nesting areas by golden eagles (Aquila chrysaetos), peregrine (Falco peregrinus) and prairie falcons, and other birds of prey. Bald eagles (Haliaeetus leucocephalus), turkey vultures (Cathartes aura), goshawks (Accipiter gentilis), and red-tailed (Buteo jamaicensis), ferruginous (Buteo regalis), rough-legged (Buteo lagopus), Cooper's (Accipiter cooperii), northern ha ier (Circus cyaneus), and sharp-shinned (Accipiter striatus) hawks also occupy this habitat. Canada geese (Branta canadensis) nest along the Green and Yampa rivers as well as on the canyon ledges in Lodore Canyon - an unusual phenomenon (Meyer and Riches 1979:2; NPS 1986:178). Gambel's quail (Lophortyx gambelii) is also present in the area today and may have been a food source for prehistoric human populations.

The Green River contains a variety of fish, including rai, mykiss), humpback chub (Gila cypha), Colorado squawfish (Ptychocheilus lucius), and others.

\subsection{REGIONAL PREHISTORY}

The cultural-historical sequence of prehistoric occupations in the affected environment is usually treated as part of the broader scheme for the Eastern Great Basin and to a lesser extent for the Northwestern Plains as defined by Aikens (1978) and Frison (1978). The prehistoric cultural chronology of the study area can be divided into the PaleoIndian or Pre-Archaic period (10,000 to 7,500 B.C.); the Archaic period - which is further subdivided into the Early (7,500 to 4,000 B.C.), Middle (4,000 to 2,000 B.C.), and Late Archaic (2,000 B.C. to A.D. 650) periods; the Late Prehistoric period (A.D. 650 to 1.200), which includes the Fremont Culture; and the Protohistoric period (A.D. 1200 to 1650), terminating at the onset of Euro-American contact (Aikens 1983:169-176; Grady 1984:20-52; Aikens and Madsen 1986:149-160; Jennings 1978:17-240, 1986:114-116; Marwitt 1986:161-172). Within this general sequence, a myriad of local developments may be defined. The discussions presented here are intended to illustrate broad patterns characteristic of each phase of cultural development represented in the study area. 


\subsubsection{Paleo-Indian Period (10,000 to 7,500 B.C.)}

The oldest known period in which cultures appear throughout North America in the archaeological record is referred to as the Paleo-Indian period (10,000 B.C. to 7,500 B.C.). The Paleo-Indian period is characterized by small, highly mobile populations that subsisted primarily through hunting of late glacial and post-glacial big-game animals - such as the mammoth (Mammuthus sp.), mastodon (Mammut americanum), and bison (Bison antiquus) - and, to a lesser extent, through the gathering of wild plant foods. As elsewhere throughout western North America, at least three Paleo-Indian complexes have been identified for the region based on distinctive lanceolate projectile point types: Clovis, Folsom, and Plano (Jennings and Norbeck 1964; Frison 1978; Cordell 1984; Jennings 1989).

The Clovis complex is dated from approximately 10,000 to 9,000 B.C. and is represented by diagnostic fluted projectile points. Clovis kill sites are widely distributed across western North America. They often contain remains of mammoth (Mammuthus columbi) and other extinct large mammals (Frison 1978; Jennings 1989). The nearest Clovis site to the Green River study area is the Union Pacific Mammoth site, which is located near the Little Snake River on Muddy Creek south of Rawlins, Wyoming. However, evidence at this site is tenuous due to the lack of diagnostic artifacts (Truesdale et al. 1989:11). Isolated Clovis points have been found in the Skull Creek drainage, south of Dinosaur National Monument, and a Clovis point was recovered from site 5RB2263, south of Rangely in Rio Blanco County, Colorado (Grady 1984:22).

The Folsom complex was relatively brief, dating from roughly 9,000 to 8,500 B.C. It is also characterized by fluted projectile points, which are smaller and broader than Clovis points. These points are often found associated with the remains of extinct forms of bison (Bison antiquus), reflecting a subsistence shift from the preceding Clovis period (Frison 1978). Although no major Folsom sites are known within the study area, isolated finds of Folsom points have been reported within Dinosaur National Monument (Truesdale et al. 1989:11). In eastern Utah, the Folsom tradition is represented by scattered surface finds and amateur collections (Horne-Sorenson 1982:7). Several major Folsom sites occur in Colorado, but none is located near the study area in the northwestern part of the state (Grady 1984:21).

The final complex of the Paleo-Indian period, loosely defined as Plano, ranges from 9,000 to 7,000 B.C., overlapping with the Folsom complex. It contains post-Clovis artifacts represented by various projectile point forms from many areas of the Eastern Great Basin, including the Colorado Plateau and the Great Plains. These points have usually been found in association with modern animal species such as antelope, elk, mule deer, and modern bison (Bison occidentalis) (Jennings 1968; Schroedl 1977; Frison 1978). Plano-related sites have been reported near the study area, and include the first concrete archaeological representation of human settlement in the area. Near Dinosaur National Monument, the lower levels of Hogup Cave (Aikens 1978) and Danger Cave (Jennings 1957) in northwestern Utah, Cowboy Cave in southeastern Utah (Jennings 1978), and Sudden Shelter in central Utah (Jennings 1978; Jennings et al. 1980) contain occupations belonging to this complex. The Great Basin Lake Mojave (9,000 to 7,000 B.C.) was present in the earliest levels of 
Swelter Shelter (Breternitz 1970:133). Within Dinosaur National Monument itself, isolated finds of Plains Agate Basin (8,500 to 7,500 B.C.) have been discovered, and Cody complex sites are well documented. Scottsbluff $(8,500$ to 7,500 B.C.) points were recovered from the lower levels of Deluge Shelter (42UN1) (Leach 1970) and elsewhere within the monument (Breternitz 1970). These types of materials are also present in the archaeological record of southwestern Wyoming (Frison 1978; Truesdale et al. 1989:12).

\subsubsection{Archaic Period (7,500 B.C. to A.D. 650)}

The Archaic period in North American prehistory represents a gradual change from Paleo-Indian big-game hunting to a subsistence based principally on gathering wild plant foods and hunting smaller game. Archaic period sites are found all over the North American continent; however, unlike the Paleo-Indian period cultures, they exhibit distinct cultural diversity among regional and local groups.

The Archaic Period can be divided into three phases: Early (7,500 to 4,000 B.C.), Middle (4,000 to 2,000 B.C.), and Late (2,000 B.C. to A.D. 650) (Aikens and Madsen 1986), although the dating varies (Schroedl 1976; Holmer 1978). In the Colorado Plateau, the Archaic is also referred to as the Desert culture or Desert Archaic culture, which is found throughout the Southwest, Great Basin, northern Mexico, and Colorado Plateau (Jennings and Norbeck 1964). The Desert Archaic differs significantly from the preceding Paleo-Indian period, and reflects an adaptation to arid and semiarid environments with limited water and sparse vegetation. The economy was based on a highly mobile settlement pattern designed to exploit seasonally available resources, with an emphasis on seed collecting and small game exploitation. The more varied tool assemblage of the Archaic apparently reflects this generalized subsistence strategy. Diagnostic artifacts include slab milling stones, small manos, digging sticks, atlatls, netting, baskets, awls, slab-lined cists, and woven sandals (Jennings 1978, 1989:150).

During the Early Archaic Period (7,500 to 4,000 B.C.), human populations appear to have increased dramatically, peaking at about 4,400 B.C. (Schroedl 1976). Surveys of Eastern Great Basin sites, such as Danger and Hogup caves, have shown that the Early Archaic sites were located near marsh and lake environments (Aikens 1983:169; Aikens and Madsen 1986:154-155). Resources such as waterfowl, shorebirds, and small mammals were exploited much more frequently than the larger herbivores. However, animals such as bison, deer, antelope, and bighorn sheep appear to have been frequently exploited as well (Aikens 1983:169). Jennings (1978:75) notes that the mule deer was most abundant in the faunal assemblages of all the Archaic levels at Deluge Shelter. Cave deposits also contained a large amount of seeds and other plant remains, which indicates a heavy reliance on these resources for food and other nonedible items. Baskets, mats, and net fragments were discovered in almost all of the Eastern Great Basin cave sites (Aikens 1983:169-172). The Eastern Great Basin lithic assemblages during the Early Archaic period contain large, side-notched projectile points and knives. Diagnostic projectile point types associated with Early Archaic occupations include the corner, side-notched, and eared point series (e.g., Elko, Pinto, and the concave-based Humbolt Series) (Jennings 1986:117). 
The Middle Archaic period (4,000 to 2,000 B.C.) in the Eastern Great Basin corresponds to the early Black Rock archaeological phase (Aikens and Madsen 1986:157). Type sites such as Deluge Shelter, Hells Midden, and Thorne Cave contain Middle Archaic levels of occupation (Jennings 1978:75-81). The Middle Archaic period coincides with the Altithermal climatic shift, which caused increased aridity in the environment of the lowland areas that had been previously exploited by prehistoric populations. One significant change was the abatement of the marshland and lake margin environments. This climatic shift is a possible indication of why there were changes in settlement patterns and in the subsistence strategy of the groups during this period. The archaeological record suggests an overall increase in the population throughout the Eastern Great Basin at this time, with sites being more abundant in the upland zones where new resources were exploited. The population relied more heavily on the hunting of game species that replaced the marshland/lake resources (Aikens 1983:169-170; Aikens and Madsen 1986:157-158). The diagnostic projectile point types from the Early Archaic continue to be the dominant types in the Middle Archaic of the Eastern Great Basin, with the addition of lanceolate types such as the McKean Lanceolate (Jennings 1986:117).

The Late Archaic (2,000 B.C. to A.D. 650) in the Eastern Great Basin parallels the latter half of the Black Rock archaeological phase (Aikens and Madsen 1986:158). Late Archaic horizons at Deluge Shelter, Swelter Shelter, Thorne Cave, and Hells Midden are present (Aikens 1983:172; Jennings 1978:81; Leach 1970:133). During this period, climatic changes produced a wetter and cooler environment, which caused a rise in pond and lake levels. This increase in water resulted in inundation of the marsh and lake margin habitats that had been accessible to prehistoric populations during the Early Archaic period (Aikens 1983:172). The archaeological record shows that the upland zones continued to be occupied because of the absence of the marshland/lake margin ecosystem due to flooding. The paucity of waterfowl, shorebirds, and marshland plant species in the archaeological record from this time further supports this hypothesis (Aikens and Madsen 1986:158). Subsistence strategies do not appear to differ much from those of the Middle Archaic period, and populations appear to have increased overall in the Eastern Great Basin (Aikens and Madsen 1986:158). The use of the Elko, Pinto, Humbolt, and McKean projectile point types continued through the Late Archaic period. Rosegate Series corner and side-notched points, Eastgate points, and Martis Series points were developed at this time and became dominant in the latter half of the Late Archaic (Jennings 1978:117).

\subsubsection{Late Prehistoric Period (A.D. 650 to 1300)}

The Late Prehistoric Period represents a shift from an economy based solely on hunting and gathering to one at least partly based on agriculture (Willey and Phillips 1958). However, hunting and gathering continued to play a major role in the economy, and in many respects the subsistence pattern was similar to that of the Archaic period (Grady 1984:40-41). In the Green River study area, the Late Prehistoric Period is represented by the Fremont culture. The term "Fremont" refers to a widespread group of cultures found all over the Eastern Great Basin following the Late Archaic period until about A.D. 1200 to 1300. The 
Fremont appears to consist of separate local variants that developed out of the local Archaic populations rather than having migrated from outside the area (Marwitt 1986:161-164). The Fremont is characterized by a change to a more sedentary lifestyle in villages and the adaptation to horticulture to supplement the existing foraging and hunting subsistence cycle (Marwitt 1986:161-164). The main cultigen was corn, with some evidence of beans and squash (Aikens 1983:172-173; Grady 1984:39; Jennings 1978:155-156; Marwitt 1986:162-163). The Fremont is also associated with cultural remains such as pithouses, substantial aboveground structures, the introduction of pottery, and the appearance of unique rock art and modeled clay figurines (Marwitt 1986:161-163).

The Fremont has been divided into five regional variants, although there is some debate regarding the validity of these divisions. The Uinta Fremont (A.D. 600 to 950) in the northern Colorado Plateau is the most relevant to the current investigation, but other influences should not be discounted (Hogan and Sebastian 1980; Horne-Sorenson 1982:11; Truesdale et al. 1989:18). The Uinta Fremont is a distinctive local variant that appears to have developed out of the Late Archaic in the Uinta Basin. Important characteristics of this variant include the presence of shallow pithouses and free-standing structures and the complete absence of Fremont clay figurines and "Utah type" metate. Large, shouldered Fremont blades, triangular and ovoid blades, and corner and side-notched projectile points are also present (Marwitt 1986:169-170).

Two original cultural phases have been identified for the Uinta Fremont: the Cub Creek phase (A.D. 650 to 800) and the Whiterocks phase (A.D. 800 to 950). The Cub Creek phase is characterized by pithouse villages containing undecorated Uinta Gray pottery. Rose Spring corner-notched projectile points appear just prior to, and continue throughout, the Cub Creek phase. The Whiterocks phase consists of the same cultural traits as the Cub Creek phase and several additions - such as the first masonry and adobe structures, decorated Uinta Grayware, and small amounts of trade pottery from other Fremont culture areas (Grady 1984:39; Jennings 1978:179-184; Marwitt 1986:169-170). Diagnostic projectile point types such as the Bear River and Uinta Side-notched are also found during this period. A third phase was later defined as the Book Cliffs phase (A.D. 950 to 1200). Sites included in this phase are located on high buttes or canyon heads and are characterized by oval or circular surface structures and an absence of free-standing storage structures (Grady 1984:39).

The Fremont cultural traits seem to disappear completely from the Uinta Basin by A.D. 1200 (Jennings 1978:179-184; Grady 1984:39; Marwitt 1986:171-172), although it is not known exactly what caused the abandonment of the Fremont lifestyle. Leach (1970) notes that the latest Fremont level at Deluge Shelter contained distinct faunal and floral evidence and different projectile point and grinding stone styles, which indicates a shift from horticulture back to one of foraging and hunting (Marwitt 1986:170). 


\subsubsection{Protohistoric Period (A.D. 1300 to 1800)}

The Protohistoric period is characterized by the northeastern migration of Southern Numic-speaking groups into the Great Basin from southern California and northern Mexico (Lamb 1958). The Southern Numic speakers belong to a branch of the Uto-Aztecan linguistic family that moved into the eastern portion of the Great Basin around A.D. 1200 and either replaced the Fremont populations or mixed with them, spreading rapidly throughout the area (Callaway et al. 1986:336; Grady 1984:47-48). By A.D. 1300, these groups had reached the Uinta Basin. The Numic speakers were ancestral to the Ute, who were encountered in the area by the first Euro-American explorers. Specifically, the White River and Uintah bands of the Ute resided in the Uinta Basin region at this time and are likely to be the descendants of the Protohistoric groups in the study area. They are described as having a subsistence regime much like that of the Archaic populations before them. They appeared to be highly mobile, exploiting a variety of plant resources for food, clothing, and supplies; and they hunted small mammals and large herbivores, such as bison, mule deer, and antelope (Callaway et al. 1986:340-341; Grady 1984:48). The Desert Side-notched projectile point, used with the bow and arrow, and the production of distinct "flower pot" brownware pottery are the hallmarks of the Numic groups in the Uinta Basin (Callaway et al. 1986:336; Truesdale et al. 1989:20).

The Protohistoric Ute period can be subdivided into three cultural phases on the basis of a study of the Eastern Ute by Reed (1988). This chronology provides some understanding of the Ute of the Uinta Basin. Sites from the Chipeta phase (A.D. 1200 to 1400) contain no Euro-American historic artifacts and appear to represent an Archaic lifestyle. Wik..ps, Desert Side-notched points, and Cottonwood triangular points are common, as are Shoshonean knives. The Canella phase (A.D. 1400 to 1650) refers to the time period between the hunter-gatherer lifestyle of the Ute and the first contact with the Spanish. Sites contain lithic artifacts such as those found in the Chipeta phase, along with brownware ceramics and some Spanish historic artifacts. The Antero phase (A.D. 1650 to 1880), actually in the Historic period, represents the shift to a lifestyle based on the introduction of the horse. Euro-American artifacts appear in these sites, and the tepee was adopted as the principal dwelling rather than the traditional wickiup structure (Truesdale et al. 1989:21).

\subsection{REGIONAL HISTORY}

\subsubsection{Early Exploration and the Fur Trade}

The first documented travel through the study area occurred in 1776, when an expedition led by two Franciscan friars, Dominguez and Escalante, crossed the Green River valley above present-day Jensen, Utah (Auerbach 1943:41-42, as cited in Lennon et al. 1980:169; Baker and Hafen 1927:277). Euro-Americans first passed through the Green River valley in 1812, when a party of Astorians returning east crossed the region on their way to South Pass, Wyoming (BLM 1986:45). 
The first recorded Euro-American group to explore the study area was a party of trappers from Missouri led by General William Ashley in 1825. (However, the first to explore and trap in the region were probably anonymous trappers from Taos or perhaps even an earlier British or French explorer.) Ashley initiated the famous rendezvous tradition, which became associated with the Green River/Western Slope fur trade for at least the next 15 years. By using a yearly rendezvous arrangement, Ashley eliminated the expense of maintaining a permanent post while garnering the full benefits of having a post established in the region (Hafen 1948). Ashley in his exploration of the study area also became the first Euro-American to boat down the Green River.

Tradition suggests that a trapper known by the name of Baptiste Brown was the first European to winter in the valley (Eddy et al. 1932:26-28). Browns Park (also called Browns Hole), the broadening of the Green River valley below Flaming Gorge and above Lodore Canyon, may have been named for this first European resident. Historians can only speculate about the origins of the name Browns Park, but a French-Canadian trapper working out of Taos by the name of Jean-Baptiste Chalifoux is known to have operated in the region. It has been suggested that Chalifoux may have been the mysterious Baptiste Brown.

It is known that in 1831-1832, a party of trappers led by Colonel Robert Bean wintered in the valley. Later, a member of that party, Prewett Sinclair, along with two other trappers, Philip Thompson and William Craig, established Fort Davy Crockett at the lower end of Browns Park (Eddy et al. 1982:34; Hafen 1972:9). The fort is recorded as existing from at least 1838 to 1840 . Thomas Farnham, leader of an Oregon-bound party that visited the fort in 1839, described the structure as a "hollow square of one story log cabins, with roofs and floors of mud construction..." (Hafen 1972; Eddy et al. 1982:41). In the absence of authenticated evidence of the existence of Baptiste Brown, it appears that Fort Davy Crockett is the first recorded Euro-American occupation of the Green River study area.

Difficulties developed between the men running Fort Davy Crockett, causing the partnership to dissolve in 1840. However, the breakup of the partnership did not stop others from visiting Browns Hole to trade with the Indians. Throughout the 1840 s, other traders are recorded as having visited the area. Browns Park was a popular wintering ground for the Snake River Shoshone. Traders who wintered in the valley also recorded the presence of Utes and Navaho, who came north to trade furs with the trappers and to race horses against the Shoshone. Fort Davy Crockett was abandoned by the mid-1840s (Eddy et al. 1982:51-53).

The abandonment of Fort Davy Crockett coincided with a general decline in the fur trade. From this point on, the traders did less trapping themselves and relied more on the Indians to provide the pelts. Also, the trade animal of choice changed from the beaver to the buffalo (Eddy et al. 1982:96-99). However, even though the fur trade declined, forts began to be established along the wagon trails that were developing across the region. 


\subsubsection{Westward Trails and River Ferries}

Westward travel along the trails first blazed by fur trappers began in the mid-1830s. The ability to cross the Rocky Mountains with wagons was first demonstrated in 1832 by the Bonneville party. Bonneville crossed over South Pass with wagons on a trip to the upper Green River, where he established a short-lived post (Chittenden 1954:431). The first westward-bound wagon travelers included fur traders, Oregon-bound missionaries, and an occasional immigrant. Homesteaders did not follow in numbers until the $1840 \mathrm{~s}$. The Mormon trek west from Illinois began in 1846, with the first party reaching Salt Lake Valley in 1847 (BLM 1986:46). Use of the westward trails increased significantly in 1849 with the California gold rush. The Oregon Trail received nominal use throughout the 1850 s and 1860 s, with a growth in traffic during the Colorado gold rush of 1859 and the post-Civil War years of 1865-1866. Heavy use of the trail ended in 1869 when the transcontinental railroad was completed, although the trail continued to be used by those who could not afford the price of the of rail transit and by local wagon drivers until the early twentieth century (BLM 1986:48, 51).

Most historic trails and ferries were located north of the study area in the Wyoming Basin, but a few routes crossed Flaming Gorge, Browns Park, and Dinosaur National Monument. Although not specifically part of the Oregon/Mormon trail group, the Overland or Cherokee Trail traverses the study area, crossing the Green River at a location currently under the waters of Flaming Gorge Reservoir. The trail was first blazed by Cherokee Indians on their way to the California gold fields, and it received subsequent use most notably as the Overland Mail Route during 1862-1869 (Mehls 1985).

Ferries were essential to this cross-continental travel. Depending upon the amount of winter snowfall, it was usually necessary for immigrants to ferry their wagons across the Green River from spring to mid-summer when runoff waters subsided. The first people to operate a ferry along the Green River were the Mormons, who established ferries north of the study area at the Sublette Cutoff crossing in 1848 (Morgan 1960:52-53) and along the Mormon Road at a location known as Lombard Ferry in 1847 (Kimball 1991:56).

Ferries were also established in the study area within Browns Park. Norman and Merrill (1981) note several local ferries in this region, one at the Jarvie Ranch at tr- upper end of Browns Park, another (Gray's Ferry) approximately $2.8 \mathrm{mi}$ downstrear from the Jarvie Ranch, and a third (the remains of Carr Ferry) at the southern end of Browns Park near Vermillion Creek. The Brinnegar Ferry is said to have been located at Linwood, which is situated near the south end of Flaming Gorge Reservoir (Purdy 1959:34; Webb 1986:54).

\subsubsection{Development of Ranching}

After the departure of the fur traders from Browns Park, the next group to take up residence in the area was cattle ranchers. In the 1850 s and $1860 \mathrm{~s}$, the area became known as a prime wintering location for cattle being driven up from Texas. A member of Major John Wesley Powell's party, on an exploratory expedition to the area in 1868, noted a large herd 
of cattle wintering in the valley (Webb 1986:58). Initially, cattle that wintered in Browns Park were driven west in the spring to pastures in California and later in Montana. After the construction of the Union Pacific Railroad, they were driven from the park to some convenient terminal along its lengt?.

The large herds that wintered in the valley soon attracted smaller, opportunistic ranchers who began to settle the valley in the early 1870s. The area gained a reputation as a haven for rustlers and outlaws, and the valley was a known stop on the so-called "Outlaw Trail." In later years, Butch Cassidy and his gang frequented the valley. Besides containing residents sympathetic to outlaws, the natural elements of rugged terrain and numerous canyons made Browns Park a good hiding place for those seeking sanctuary from the law (Norman and Merrill 1981:16). The rustling of cattle from large herds in the region was stopped in 1900 when a Wyoming cattleman brought in a hired gun, Tom Horn, to control the problem. He killed two of the suspected rustlers, effectively putting an end to this practice in the area (Burroughs 1962:207-214).

Some hardy pioneers attempted dry farming in the region after 1900, but for the most part these efforts had proved unsuccessful by the 1930s. Some initial success was achieved despite several dry years from about 1913 to 1920, but with the onset of depression and drought in the 1930s, most dry farming efforts were abandoned. With the failure of dry farming, residents in the region returned to using the land for livestock grazing (BLM 1986:51). Farming in the area only prospered with the advent of irrigation ditches, which were first dug in the Browns Park region in the early 20th century (Woodward-Clyde 1985:3-15). Farmers using irrigation systems in the region produced predominately alfalfa, grain, and root crops (Burroughs 1962:271).

\subsection{REGIONAL ETHNOGRAPHY: UTE}

The Ute, who speak one of the languages from the Southern Numic branch of the Uto-Aztecan language family, probably arrived in the Great Basin sometime between A.D. 1200 and 1400; however, the earliest Spanish accounts of Ute presence in the area are from the 17th century (Reed 1984:43; Truesdale et al. 1989:21; Woodward-Clyde 1985:B-23). The Ute inhabited the region bordered by the Oquirrh Mountains on the west, the Uinta Muuntains on the north, the San Juan Mountains on the south, and the Front Range of the Rocky Mountains on the east (Callaway et al. 1986:336). On occasion, they ventured as far west as California (Hart 1874:33). Because of this wide range of territory, the Ute inhabited both study areas covered in this report (Green River and Gunnison River). Today the Ute are located on several reservations in Colorado and Utah (Table 1).

\subsection{1 ristory}

The Ute were first encountered in the 17th century by the Spanish, who began to penetrate the Great Basin from Mexico City in order to colonize the Great Basin and 
TABLE 1 Native American Tribes in the Green River Study Area

\begin{tabular}{ll}
\hline \multicolumn{1}{c}{ Name } & \multicolumn{1}{c}{ Address } \\
\hline $\begin{array}{l}\text { Southern Ute Indian Tribe of } \\
\text { the Southern Ute Reservation }\end{array}$ & $\begin{array}{l}\text { Southern Ute Tribal Council } \\
\text { Tribal Affairs Building } \\
\text { P.O. Box 737 } \\
\text { Ignacio, CO 81137 } \\
\text { (303) 563-4425 }\end{array}$ \\
$\begin{array}{ll}\text { Ute Mountain Tribe of the Ute } \\
\text { Mountain Reservation }\end{array}$ & $\begin{array}{l}\text { General Delivery } \\
\text { Towaoc, CO 81344 }\end{array}$ \\
& $\begin{array}{l}\text { (303) 565-3751 } \\
\text { Ute Indian Tribe of the Uintah }\end{array}$ \\
$\begin{array}{l}\text { Uintah \& Ouray Tribal } \\
\text { Business Council } \\
\text { Fort Duchesne, UT 84026 }\end{array}$ \\
\end{tabular}

California. The first documented encounter occurred in the 1630s, when reports of Ute and Spanish battles filtered down to the Spanish headquarters in Santa Fe. A number of these skirmishes continued throughout the 17th century (Marsh 1982:14-16).

At this time, the Spanish introduced the horse into Ute culture, which forever changed the traditional Ute way of life. The horse facilitated movement into the plains, where the Ute contacted other tribes. Prehorse alliances, like that with the Comanche, remained intact, but trade networks and other relationships between the Utes and plains tribes (e.g., the Arapahoe, Kiowa, and Sioux) were formed as a result of long-range mobility provided by the horse. The subsistence strategy changed rapidly to one based on bison hunting. The Ute acquired a reputation among the Spanish and neighboring tribes for being extremely fierce and cunning in battle. Eventually, the acquisition of the horse also led to inevitable adverse effects on many of the aboriginal populations by facilitating raiding and aboriginal slave trading. The Utes became quite adept at raiding the Spanish and neighboring tribes and at supplying the Spanish with aborigines from other tribes, particularly the Pueblos (Malouf and Findlay 1986:500-502; Marsh 1982:15-16).

In 1776, an expedition led by Francisco Atanasio Dominguez and Silvestre Velez de Escalante reached the Ute territory, allowing the first glimpse of Ute culture through written accounts. Dominguez documented subsistence activities such as fishing, gathering of nuts and seeds, and harvesting of prickly pear cactus. The explorers also reported that the Ute were cultivating corn. Trade alliances with the Spanish were formed through this meeting (Malouf and Findlay 1986:503-508). 
In 1779 , the Comanche, a long-time ally of the Utes, became involved in a battle with the Spanish and the Ute, terminating that alliance. The continued war and raiding caused similar breakdowns between the various tribes all over the West.

After the Spanish lost control of land in North America in 1821, populations of Mexicans and Americans continued to move into the Great Basin in large numbers. By the 1830 s, the Ute were heavily involved in the fur trade with the Euro-Americans, Shoshone, and other tribes. They frequented Fort Davy Crockett in Browns Park, one of the first fur trade centers and outposts in the Rocky Mountains (Eddy et al. 1982:23). Although in some cases the trade networks strengthened ties between the Euro-Americans and the Utes, it also had an adverse effect on the Ute population because many of the animals exploited for fur had once been relied upon for food and clothing (Malouf and Findlay 1986:503-508).

The Ute continued to lose their land after the Mexican-American War. By 1847, the Mormons and other Euro-American settlers began to encroach on Ute territory at an alarming rate. Battles between the whites and Native Americans (including the Ute) continued as miners and ranchers moved farther into the intermontane west. After a series of treaties were signed between the Utes and the United States government in the $1860 \mathrm{~s}$, the Ute landholdings dwindled from approximately 86 million acres in Colorado and Utah to 15 million acres in Colorado and only 2 million in Utah. The 2 million acres in Utah became the Uintah Reservation in 1862 . In 1868 , the 15 million acres remaining was divided between the Southern Ute and the Ute Mountain Ute reservations. Following the Dawes Severity Act of 1887, the Southern Ute Reservation was reduced to 40,600 acres and the Ute Mountain Ute Reservation to 513,000 acres. In 1879, the Meeker Massacre made news around the world and prompted the government to forcibly relocate all remaining Utes to the reservation (Marsh 1982:87-100). As a final attempt to resist white encroachment, the Utes of Utah participated in the Ghost Dance of the 1870s. Some of the members returned to Colorado following the Ghost Dance to attempt to resist white expansion, but these efforts also failed. In 1882, the government established the Ouray Reservation for the Uncompahgre band of Ute; the Ouray Reservation and adjacent Uintah Reservation were later combined into one reservation (Callaway et al. 1986:355-357).

\subsubsection{Ethnography}

When the first Euro-American settlers reached Ute territory, tribes consisted of separate bands. The bands were loosely organized clusters of extended kin groups that were highly mobile and exchanged members continually through marriage and other social purposes (Callaway et al. 1986:338-340; Marsh 1982:17-19). The bands can be classified into a western band from Utah and an eastern band from Colorado, or into southern and northern bands. Therefore, the eastern bands of Muache, Capote, and Weeminuche are also considered to be southern bands that originally resided in southern Colorado, northern New Mexico, and southeastern Utah. The eastern bands of the Uncompahgre (Taviwach), Parusanuch, and Yampa are northern Ute bands. The Pahvant and Moanunt bands were western groups that eventually joined the Southern Paiutes of southwestern Utah (Callaway et al. 1986:340-342). The other western bands - the Uintah, Timpanogots, and Sanpits - are considered to be 
northern Utes. The bands associated with the Green River study area during the Protohistoric and Historic periods were the Uintah band and the White River band, which included .the Parusanuch and the Yampa. Today, descendants of these bands and the Timpanogots, Sanpits, and Uncompahgre all reside on the Uintah and Ouray Reservation of northeastern Utah (Callaway et al. 1986:340-342; Marsh 1982:19-21).

The Ute were primarily hunters and gatherers. They spent the warmer months of the year moving in small groups through the higher mountains; during the winter, most groups moved to the warmer southern portions of their territory (Hughes 1977:27). The Ute hunted mule deer, elk, mountain sheep, pronghorn, and buffalo, although they did not begin hunting buffalo until they acquired horses from the Spanish in the late 17th century (Delaney 1989:11). The Ute also relied on the hunting of smaller game species, especially jackrabbits (Hughes 1977:27), and fished when small game and other food supplies were scarce (Marsh 1982:169, 171). The Uintah Ute that inhabited the Utah Valley relied more heavily on fishing than did the other groups (Janetski 1991:36-37).

Wild plant foods also were an important part of the Ute diet. They gathered roots and tubers of the yampa plant, camas bulbs, yucca, grass seeds, sunflower seeds, berries, piñon nuts, and acorns (Hughes 1977:27-28). Also used for food were the prickly pear, tobacco root, camas root, bark of pine trees, and sap from aspen trees (Marsh 1982:171). During harvest time, several families would usually camp together and would eat the nuts or acorns and venison for quite some time before moving on to another camp locality. Food was stored in underground pits beneath a cliff overhang, or a hearth was constructed on top to conceal the contents of the pit. Although there is no archaeological evidence to suggest that the Utes were horticulturalists, some Ute informants had reported that small amounts of corn, beans, and squash cultivation had taken place prior to the expansion of white settlers in the 1860s (Hughes 1977:27; Callaway et al. 1986:343-344; Malouf and Findlay 1986:503-508; Marsh 1982:12, 170).

The characteristic Ute living structure was the conical-shaped brush house. These structures were built with four-pole foundations and were 10 to $15 \mathrm{ft}$ in diameter. Some Ute bands also constructed willow houses, which had convex-shaped roofs covered with willow boughs and lacked a smoke hole. They stood approximately $8 \mathrm{ft}$ high and $15 \mathrm{ft}$ in diameter. These dwellings may have been used during the summer, although some may have been occupied year-round. Tepees were adopted after the Spanish introduced the horse into Ute culture. The tepee facilitated the highly mobile lifestyle that the horse allowed and the buffalo hunt required, although Ute camps continued to be a mixture of traditional brush houses and skin tepees well into historic times. Ute camps were usually arranged in a random fashion, but they were always situated where wood and shade were plentiful (Callaway et al. 1986:348-350).

The Utes are known for their leather goods and basketry. Buckskin, the preferred material for clothing, was tanned and stretched for several days before it could be used. Baskets were made from willow and squawbush, and twine and cordage were made from dogbane, yucca, nettle, and the bark of sagebrush and juniper. The cordage was then used 
to construct fishing nets, traps, ropes, and bowstrings. Rafts, mats, and blankets were also made from plant fibers. The Utes were proficient in knapping stone to manufacture a variety of tools made of chert and obsidian, including arrow points for bow and arrow hunting. Woodwork and pottery were also produced in everyday life (Callaway et al. 1986:346-348).

As in most Native American societies, religion was integrated into the daily life of a Ute individual. Religion was a personal experience intimately tied with the natural environment. Living in harmony with nature and taking only what one needed for survival was important to the Ute; if an individual became ill, it was because he was out of step with nature (Delaney 1989:9; Marsh 1982:129, 169). The Utes believed that certain individuals possessed greater powers which enabled them to communicate with the supernatural forces that existed throughout life. These individuals, or shamans, were represented by an equal number of men and women in Ute society. Religious symbols and storytelling were inherent in Ute life. All aspects of life were taught through these oral traditions. All living things were believed to possess a spirit or soul, and the bravest animals possessed the strongest spirits. The two strongest animals were the mountain lion and the bear, with the latter occupying an important role in Ute culture. They also acknowledged the existence of gods or spirits that were associated with thunder or lightning; good spirits; and even a Great Spirit that lived in the sun. A Ute myth told that the first Ute came from a hole in the earth to view the sky and forests (Marsh 1982:129-132).

Frequent visits to hot springs were also considered important to one's general wellbeing. Some of the hot springs used by the Ute included those found on the San Juan River and the tributaries of the Colorado River. One of the most popular was Fontaine qui Bouille, located near Colorado Springs (Marsh 1982:166-167).

Utes were usually buried in natural caves or rock crevices, with the body extended and the head pointed toward the east (Callaway et al. 1986:352). Occasionally, the deceased were placed in graves or on aboveground burial platforms; cremation has also been reported (Marsh 1982:168). Some material possessions were usually buried with the individual, but the remainder of the deceased's possessions were usually burned (Marsh 1982:168; Callaway et al. 1986:352; Delaney 1989:62). Burial sites were usually avoided by the living, as they were considered to possess dangerous magic (Marsh 1982:168). It is likely that burial sites may be found in the vicinity of Green River in the region inhabited by the Ute prior to their relocation to reservations (Truesdale 1991).

\subsection{PREVIOUS RESEARCH}

The earliest archaeological investigation in the Green River Basin in southwestern Wyoming was performed by several researchers working with early government explorers in the 1870s as they passed through to Yellowstone National Park. In 1873, Leidy noted stone tools located on possible campsites (Woodward-Clyde 1983). Subsequent research in southwestern Wyoming was conducted in the Church Butte area in the 1930s by E. B. Renaud. In the 1940s, excavations conducted by Baldwin and by Burgh and Scoggin took place in Dinosaur National Monument and the Castle Park area (Eddy et al. 1982). 
Those excavations first identified a culture related to the Fremont Culture, but possessing its owu distinct characteristics. In 1959, William Purdy published a history of the Flaming Gorge Reservoir area prior to dam construction, outlining the historical significance of the area and discussing prominent historical and archaeological sites (Purdy 1959).

The earliest major sampling survey within the Green River study area was undertaken prior to construction of the Flaming Gorge Reservoir. Although the methodology was somewhat unsystematic, the survey yielded 121 sites (Day and Dibble 1963). Beginning in the late 1970s and early 1980s, several major surveys took place along the Green River for example, the Peaking Power Project (Norman and Merrill 1981) and the Seedskadee Project (Drager and Ireland 1986) - in addition to numerous smaller compliance surveys, thus increasing the amount of data available on regional and local prehistory and history. Many of these surveys covered areas along the Green River that are included in the study area for this overview (Figure 2); a complete list of known surveys within the study area is presented in Table 2. Approximately 7\% of the study area has been subject to intensive archaeological surveys, and $68 \%$ has been subject to less intensive surveys (Figures 3 through 14).

The study area is a corridor extending from Flaming Gorge Dam to the mouth of Cub Creek. The minimum width of the corridor is $0.5 \mathrm{mi}$ from each bank of the river, and the maximum width corresponds to the contour interval $60 \mathrm{ft}$ above MSL (as defined on current USGS topographic maps). The corridor has been subdivided into two major reaches: (1) Flaming Gorge Dam to the Yampa River, and (2) Yampa River to the mouth of Cub Creek.

\subsubsection{Reach 1: Flaming Gorge Dam to the Yampa River Confluence}

Reach 1 is defined as the study corridor along the Green River in Utah and Colorado between Flaming Gorge Dam and the confluence of the Yampa River in Moffat County, Colorado. Twenty-six known surveys have been conducted within the study area corridor of this reach. Twenty-four of the surveys (92\%) were intensive, comprehensive ${ }^{2}$ surveys $^{2}$ utilizing pedestrian transect survey methods, and two of the surveys (8\%) used systematic random sampling methods (Madsen and Sargent 1979; Norman and Merrill 1981). Among the systematic random sampling surveys was the Peaking Power Project, which examined a 200 - $\mathrm{ft}$ corridor on each side of the river (40\% sample) between Flaming Gorge Dam and Dinosaur National Monument (Norman and Merrill 1981). Seven surveys yielded negative results (27\%); the remaining 19 surveys discovered 111 sites and relocated 5 previously recorded sites. Overall, about $10 \%$ of the study area within this reach has been subject to an intensive archaeological survey, and approximately $65 \%$ has been surveyed with nonintensive or random sampling methods.

2 Comprehensive indicates that $100 \%$ of the area was surveyed. 


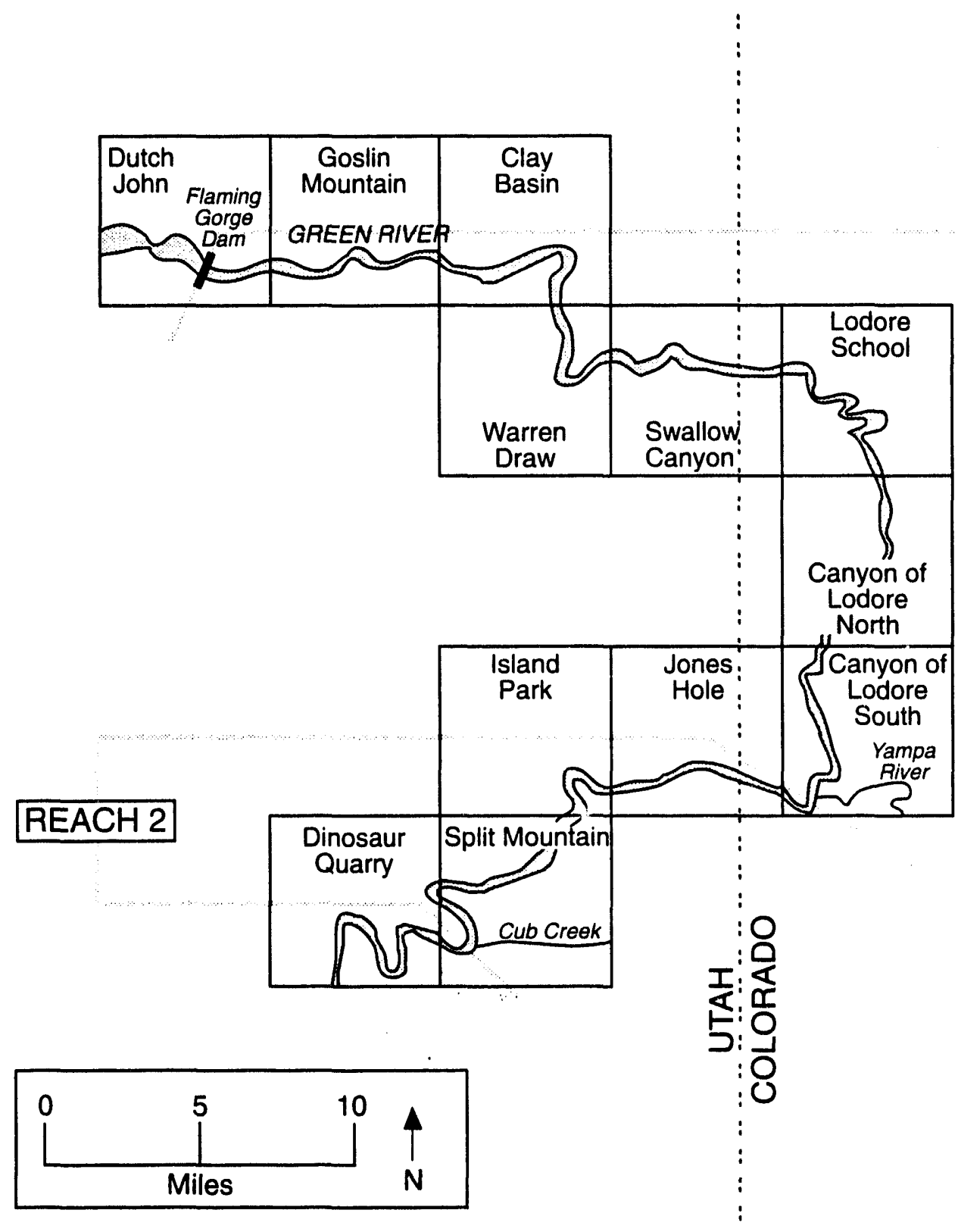

REACH 1

FIGURE 2 Green River Study Area 


\section{TABLE 2 Previous Archaeological Surveys in the Green River Study Area}

\begin{tabular}{|c|c|c|c|c|c|c|c|c|}
\hline Project Name & Year & $\begin{array}{c}\text { Area } \\
\text { Surveyed }\end{array}$ & $\begin{array}{l}\text { Percent } \\
\text { Sampled }\end{array}$ & $\begin{array}{l}\text { Survey } \\
\text { Code }^{\mathrm{a}}\end{array}$ & $\begin{array}{l}\text { Sampling } \\
\text { Procedures }\end{array}$ & $\begin{array}{c}\text { Number } \\
\text { of Sites } \\
\text { Recorded }^{b}\end{array}$ & $\begin{array}{c}\text { Number } \\
\text { in ANL } \\
\text { Database }^{c}\end{array}$ & Reference \\
\hline \multicolumn{9}{|c|}{ Reach 1: Flaming Gorge Dam to the Yampa River Confluence } \\
\hline $\begin{array}{l}\text { Bureau of Land Management } \\
\text { Antiquities Site Inventory } \\
\text { Form for Site 42DA40 }\end{array}$ & 1974 & $100 \mathrm{yd} \times 200 \mathrm{yd}$ & $100 \%$ & 3 & $\begin{array}{l}\text { Surface inventory/survey of } \\
\text { the complete site; not } \\
\text { plotted on figure. }\end{array}$ & 1 & 7FG-1 & Tucker (1974) \\
\hline $\begin{array}{l}\text { Archaeological Survey Report: } \\
\text { Dutch John Pinyon-Juniper } \\
\text { Conversion Project (July) }\end{array}$ & 1977 & Not specified & $100 \%$ & 3 & $\begin{array}{l}\text { Area surveyed in transects } \\
\text { spaced } 30 \mathrm{ft} \text { apart. }\end{array}$ & 17 & 4FG-24 & Watts (1977) \\
\hline $\begin{array}{l}\text { Archaeological Survey Report: } \\
\text { Dutch John Pinyon-Juniper } \\
\text { Conversion Project } \\
\text { (September) }\end{array}$ & 1977 & 200 acres & $100 \%$ & 3 & $\begin{array}{l}\text { Area divided into four } \\
\text { separate zones; surveyed in } \\
\text { parallel transects spaced } \\
30 \mathrm{ft} \text { apart. }\end{array}$ & 8 & 4FG-27 & Iacovetta (1977) \\
\hline $\begin{array}{l}\text { Cultural Resources Survey of } \\
\text { O.D. Ignacio to Sumas Line, } \\
\text { Dagget Co., Utah }\end{array}$ & 1978 & $9.43 \mathrm{mi}$ & $100 \%$ & 3 & $\begin{array}{l}\text { Walked transect along } \\
\text { existing pipeline outside } \\
\text { disturbed area. }\end{array}$ & 0 & 7FG-6 & Harper (1978) \\
\hline $\begin{array}{l}\text { Cultural Resource Survey of } \\
\text { the Northwest Corporation } \\
\text { Pipeline Pinyon-Juniper } \\
\text { Pushover }\end{array}$ & 1978 & 20 acres & $100 \%$ & 3 & $\begin{array}{l}\text { Area divided into } 13 \\
\text { separate units; systematic } \\
\text { survey; not specified. }\end{array}$ & 3 & 4FG-28 & $\begin{array}{l}\text { McFadden } \\
\text { (1978b) }\end{array}$ \\
\hline $\begin{array}{l}\text { Cultural Resource Survey for } \\
\text { the Little Hole Campground } \\
\text { Expansion and Mann Bench } \\
\text { Development }\end{array}$ & 1978 & Not specified & $100 \%$ & 3 & $\begin{array}{l}\text { Systematic transects; not } \\
\text { specified. }\end{array}$ & 3 & 4FG-34 & $\begin{array}{l}\text { McFadden and } \\
\text { Worthington } \\
\text { (1978) }\end{array}$ \\
\hline $\begin{array}{l}\text { Cultural Resources Survey of } \\
\text { the Flaming Gorge Peaking } \\
\text { Power Project }\end{array}$ & 1981 & $\begin{array}{l}30.2 \mathrm{mi} \times 400 \mathrm{ft} \\
\text { (approx.) }\end{array}$ & $40 \%$ & 2 & $\begin{array}{l}200 \text {-ft-wide corridor on } \\
\text { either side of the Green } \\
\text { River from Flaming Gorge } \\
\text { Dam to boundary of } \\
\text { Dinosaur National } \\
\text { Monument; } 50 \text {-ft zigzag } \\
\text { transects. }\end{array}$ & 29 & 1FG-7 & $\begin{array}{l}\text { Norman and } \\
\text { Merrill (1981) }\end{array}$ \\
\hline
\end{tabular}


TABLE 2 (Cont.)

\begin{tabular}{|c|c|c|c|c|c|c|c|c|}
\hline Project Name & Year & $\begin{array}{c}\text { Area } \\
\text { Surveyed }\end{array}$ & $\begin{array}{l}\text { Percent } \\
\text { Sampled }\end{array}$ & $\begin{array}{l}\text { Survey } \\
\text { Code }^{\mathbf{a}}\end{array}$ & $\begin{array}{l}\text { Sampling } \\
\text { Procedures }\end{array}$ & $\begin{array}{c}\text { Number } \\
\text { of Sites } \\
\text { Recorded }^{b}\end{array}$ & $\begin{array}{c}\text { Number } \\
\text { in ANL } \\
\text { Database }^{\mathfrak{c}}\end{array}$ & Reference \\
\hline Manr. Bench Borrow Site & 1984 & 1 acre & $100 \%$ & 3 & $\begin{array}{l}\text { Intensive survey; not } \\
\text { specified. }\end{array}$ & 0 & 4FG-35 & Oprandy (1984) \\
\hline $\begin{array}{l}\text { Archaeological Survey of Three } \\
\text { Seismic Lines near Dutch John } \\
\text { in Ashley National Forest } \\
\text { (Line GC4-2) }\end{array}$ & 1984 & $\begin{array}{l}15 \mathrm{mi} \times 200 \mathrm{ft} \\
\text { (approx.) }\end{array}$ & $100 \%$ & 3 & $\begin{array}{l}\text { 200-ft-wide seismic line } \\
\text { corridor; pedestrian survey } \\
50 \mathrm{ft} \text { apart, perpendicular } \\
\text { to the seismic line. }\end{array}$ & 7 & 7FG-2 & Moore (1985) \\
\hline $\begin{array}{l}\text { Archaeological Inventory of } \\
\text { One Seismic Line on Goslin } \\
\text { Mountain and in Clay Basin }\end{array}$ & 1990 & $7 \mathrm{mi} \times 100 \mathrm{ft}$ & $100 \%$ & 3 & $\begin{array}{l}\text { 100-ft right-of-way } \\
\text { surveyed in zigzag } \\
\text { transects. }\end{array}$ & 0 & 4FG-21 & Billat (1990) \\
\hline $\begin{array}{l}\text { National Register of Historic } \\
\text { Places Inventory Site Form for } \\
\text { Site } 42 \text { DA211 }\end{array}$ & n.d. ${ }^{d}$ & 0.10 acre & $100 \%$ & 3 & $\begin{array}{l}\text { Surface inventory/survey of } \\
\text { the complete site; not } \\
\text { plotted on figure. }\end{array}$ & 1 & 7FG-3 & Johnson (n.d.) \\
\hline $\begin{array}{l}\text { Archaeological Investigations } \\
\text { in Browns Park Vernal } \\
\text { District }\end{array}$ & 1976 & $\begin{array}{l}850 \text { acres; } \\
175 \text { yd } \times 75 \text { yd } \\
\text { and } 50 \mathrm{ft} \times \\
50 \mathrm{ft}\end{array}$ & $100 \%$ & 3 & $\begin{array}{l}\text { Class II survey, not } \\
\text { specified; Sites 42DA56 } \\
\text { and 42DA59, and 42DA61; } \\
\text { surface inventory/survey of } \\
\text { complete site; not plotted } \\
\text { on figure. }\end{array}$ & $4(14)$ & 6FG-2a,2b & Fike (1976) \\
\hline $\begin{array}{l}\text { Bureau of Land Management } \\
\text { Antiquities Site Inventory } \\
\text { Form for Site } 42 \text { DA52 }\end{array}$ & 1976 & $100 \mathrm{ft}^{2}$ & $100 \%$ & 3 & $\begin{array}{l}\text { Surface inventory/survey of } \\
\text { the complete site; not } \\
\text { plotted on figure. }\end{array}$ & 1 & 7FG-5 & Tucker (1976) \\
\hline John Jarvie Ranch & 1978 & 35.4 acres & $N S^{d}$ & & Historic site inventory. & 1 & $6 \mathrm{FG}-3$ & Tennent (1981) \\
\hline $\begin{array}{l}\text { Archaeological Inventory of the } \\
\text { Browns Park Land Exchange }\end{array}$ & 1979 & 600 acres & NS & 2 & $\begin{array}{l}\text { Transects spaced } 50 \text { to } \\
100 \mathrm{ft} \text { apart. }\end{array}$ & 2 & 2FG-11 & $\begin{array}{l}\text { Madsen and } \\
\text { Sargent (1979) }\end{array}$ \\
\hline $\begin{array}{l}\text { MAPCO Rocky Mountain } \\
\text { Liquid Hydrocarbons Pipeline }\end{array}$ & 1979 & 200-ft corridor & $100 \%$ & 3 & Not specified. & $1 / 1 R^{e}$ & 1GR-5 & McEnany $(1981)^{f}$ \\
\hline $\begin{array}{l}\text { Archaeological Reconnaissance } \\
\text { of the Clay Basin Seismic } \\
\text { Project }\end{array}$ & 1981 & $16 \mathrm{mi} \times 50 \mathrm{ft}$ & $100 \%$ & 3 & Single zigzag transect. & 0 & 6FG-1 & Cook (1981) \\
\hline
\end{tabular}


TABLE 2 (Cont.)

\begin{tabular}{|c|c|c|c|c|c|c|c|c|}
\hline Project Name & Year & $\begin{array}{c}\text { Area } \\
\text { Surveyed }\end{array}$ & $\begin{array}{l}\text { Percent } \\
\text { Sampled }\end{array}$ & $\begin{array}{l}\text { Survey } \\
\text { Code }^{\mathbf{a}}\end{array}$ & $\begin{array}{l}\text { Sampling } \\
\text { Procedures }\end{array}$ & $\begin{array}{c}\text { Number } \\
\text { of Sites } \\
\text { Recorded }^{b}\end{array}$ & $\begin{array}{l}\text { Number } \\
\text { in ANL } \\
\text { Database }^{c}\end{array}$ & Reference \\
\hline $\begin{array}{l}\text { PLT Engineering, Inc., } \\
\text { Chevron } \mathrm{CO}_{2} \mathrm{PO}_{4} \text { Pipeline } \\
\text { Corridors }\end{array}$ & 1985 & $\begin{array}{l}8,500 \mathrm{ft} \times 50 \mathrm{ft} \\
1,200 \mathrm{ft} \times 25 \mathrm{ft} \\
\text { in } 7 \text { areas }\end{array}$ & $100 \%$ & 3 & Single zigzag transect. & 1R & 4FG-22 & $\begin{array}{l}\text { Creasman } \\
(1985 b)\end{array}$ \\
\hline $\begin{array}{l}\text { PLT Engineering, Inc., Borrow } \\
\text { Al ea for Chevron } \mathrm{CO}_{2} / \mathrm{PO}_{4} \\
\text { Pipeline }\end{array}$ & 1985 & $340 \mathrm{ft} \times 140 \mathrm{ft}$ & $100 \%$ & 3 & $\begin{array}{l}\text { Systematic transects } \\
\text { spaced } 50 \mathrm{ft} \text { apart. }\end{array}$ & 0 & 4FG-23 & $\begin{array}{l}\text { Creasman } \\
(1985 a)\end{array}$ \\
\hline $\begin{array}{l}\text { PLT Engineering, Inc., Borrow } \\
\text { Pit for Chevron } \mathrm{CO}_{2} \mathrm{PO}_{4} \\
\text { Pipeline }\end{array}$ & 1985 & $\begin{array}{l}69,300 \mathrm{ft}^{2} \\
\text { (approx.) }\end{array}$ & $100 \%$ & 3 & $\begin{array}{l}\text { Surface inventory/survey of } \\
\text { the complete site; not } \\
\text { plotted on figure. }\end{array}$ & 1 & 7FG-7 & $\begin{array}{l}\text { Newberry } \\
\text { Archeological } \\
\text { Services (1985) }\end{array}$ \\
\hline $\begin{array}{l}\text { Cultural and Paleontological } \\
\text { Resource Inventory ... Chevron } \\
\mathrm{CO}_{2} / \mathrm{PO}_{4} \text { Pipeline Corridors, } \\
\text { Colorado, Utah, and Wyoming }\end{array}$ & 1985 & $\begin{array}{l}200 \text {-ft corridor } \\
\text { through the } \\
\text { Browns Park } \\
\text { area }\end{array}$ & $100 \%$ & 3 & $\begin{array}{l}\text { Parallel transects spaced } \\
30 \text { to } 50 \mathrm{ft} \text { apart. }\end{array}$ & $3 / 1 R$ & 1GR-1 & $\begin{array}{l}\text { Woodward-Clyde } \\
(1985)^{g}\end{array}$ \\
\hline $\begin{array}{l}\text { Browns Park Chaining } \\
\text { Archaeological Survey } \\
\text { Preliminary Report }\end{array}$ & 1986 & $\begin{array}{l}466.5 \text { acres in } \\
12 \text { parcels }\end{array}$ & $100 \%$ & 3 & $\begin{array}{l}\text { Parallel transects spaced a } \\
\text { maximum of } 65 \mathrm{ft} \text { apart. }\end{array}$ & $22(34)$ & 2FG-12 & Lindsay (1986a) \\
\hline $\begin{array}{l}\text { Additional Browns Park } \\
\text { Chaining Archaeological } \\
\text { Survey Preliminary Report }\end{array}$ & 1986 & 315 acres & $100 \%$ & 3 & $\begin{array}{l}\text { Parallel transects spaced a } \\
\text { maximum of } 50 \mathrm{ft} \text { apart. }\end{array}$ & $0(17 / 2 R)$ & 2FG-12 & Lindsay (1986b) \\
\hline $\begin{array}{l}\text { Cultural Resource Inventory of } \\
\text { the Proposed Questar North- } \\
\text { South Pipeline Project }\end{array}$ & 1988 & $200-$ ft corridor $^{h}$ & $100 \%$ & 3 & $50 \mathrm{ft}$ transects. & $\begin{array}{c}5 / 2 \mathrm{R} \\
(24 / 18 \mathrm{R})\end{array}$ & 7FG-4 & $\begin{array}{l}\text { Metcalf et al. } \\
\text { (1989) }\end{array}$ \\
\hline $\begin{array}{l}\text { Cultural Resource Survey, } \\
\text { Browns Park National Wildlife } \\
\text { Refuge }\end{array}$ & 1979 & 2,037 acres & $100 \%$ & 3 & $\begin{array}{l}\text { Parallel transects spaced } \\
40 \mathrm{ft} \text { apart. }\end{array}$ & 2 & 2FG-10 & $\begin{array}{l}\text { Meyer and } \\
\text { Riches (1979) }\end{array}$ \\
\hline $\begin{array}{l}\text { Browns Park National Wildlife } \\
\text { Refuge Survey }\end{array}$ & 1980 & 140 acres & $100 \%$ & 3 & Not specified. & $\mathbf{0}$ & 2FG-13 & Hansen (1980) \\
\hline
\end{tabular}


TABLE 2 (Cont.)

\begin{tabular}{|c|c|c|c|c|c|c|c|c|}
\hline Project Name & Year & $\begin{array}{c}\text { Area } \\
\text { Surveyed }\end{array}$ & $\begin{array}{l}\text { Percent } \\
\text { Sampled }\end{array}$ & $\begin{array}{c}\text { Survey } \\
\text { Code }^{\mathbf{a}}\end{array}$ & $\begin{array}{l}\text { Sampling } \\
\text { Procedures }\end{array}$ & $\begin{array}{c}\text { Number } \\
\text { of Sites } \\
\text { Recorded }^{b}\end{array}$ & $\begin{array}{c}\text { Number } \\
\text { in ANL } \\
\text { Database }^{c}\end{array}$ & Reference \\
\hline \multicolumn{9}{|c|}{ Reach 2: Yampa River Confluence to Cub Creek } \\
\hline $\begin{array}{l}\text { Archaeological Survey in } \\
\text { Dinosaur National Monument, } \\
\text { Colorado-Utah }\end{array}$ & $\begin{array}{l}1963- \\
1964\end{array}$ & Not specified & $40 \%$ & 1 & $\begin{array}{l}\text { Intuitive survey; } \\
\text { pedestrian walkover, } \\
\text { minimal site collection, } \\
\text { unsystematic. }\end{array}$ & $412^{\mathrm{i}}$ & 5FG-2 & Breternitz (1965) \\
\hline $\begin{array}{l}\text { Split Mountain Cultural Study } \\
\text { Tract }\end{array}$ & 1979 & 8,120 acres & $25 \%$ & 2 & $\begin{array}{l}\text { Proportional stratified } \\
\text { random sample of } 2,030 \\
\text { acres ( } 54 \text { units) actually } \\
\text { surveyed; transects spaced } \\
50 \mathrm{ft} \text { apart. }\end{array}$ & $26 / 2 \mathrm{R}$ & 1FG-6 & Holmer (1979) \\
\hline $\begin{array}{l}\text { Archaeological Investigations } \\
\text { along the Echo Park Road, } \\
\text { Dinosaur National Monument }\end{array}$ & 1989 & 193.9 acres & $100 \%$ & 3 & $\begin{array}{l}\text { Road corridor, } 8 \mathrm{mi} \times 100 \\
\text { to } 200 \mathrm{ft} \text {; surveyed in two } \\
\text { parallel transects with } \\
\text { intensive surveys of site } \\
\text { locations. }\end{array}$ & $26 / 7 \mathrm{R}$ & 3FG-16 & $\begin{array}{l}\text { Truesdale et al. } \\
\text { (1989) }\end{array}$ \\
\hline
\end{tabular}

a Survey code: 0 , type of survey not specified in report or data incomplete; 1 , unsystematic survey - includes random walkovers, compilations, etc.; 2 , sampling methods used; 3 , intensive survey, usually covering $100 \%$ of area.

b Number in parentheses is total number of sites recorded during survey; first number denotes number of sites in the specific area.

c Survey number in ANL database; corresponds to numbered survey areas on Figures 3 through 8.

d n.d. indicates no date, survey or report date unknown.; NS indicates not specified.

- $\mathbf{R}$ indicates number of sites relocated (i.e., previously recorded in another survey).

f Survey/site information also contained in Woodward-Clyde (1982), ANL database number 1GR-6; and Woodward-Clyde (1983), ANL database number 1GR-7.

8 Survey/site information also contained in Tucker (1986), ANL database number 1GR-2.

h The corridor is only $50 \mathrm{ft}$ in length, running along existing pipelines; the pipeline runs from Clay Basin to Fidlar Compressor Station.

i Includes sites in Dinosaur National Monument outside of current study area. 


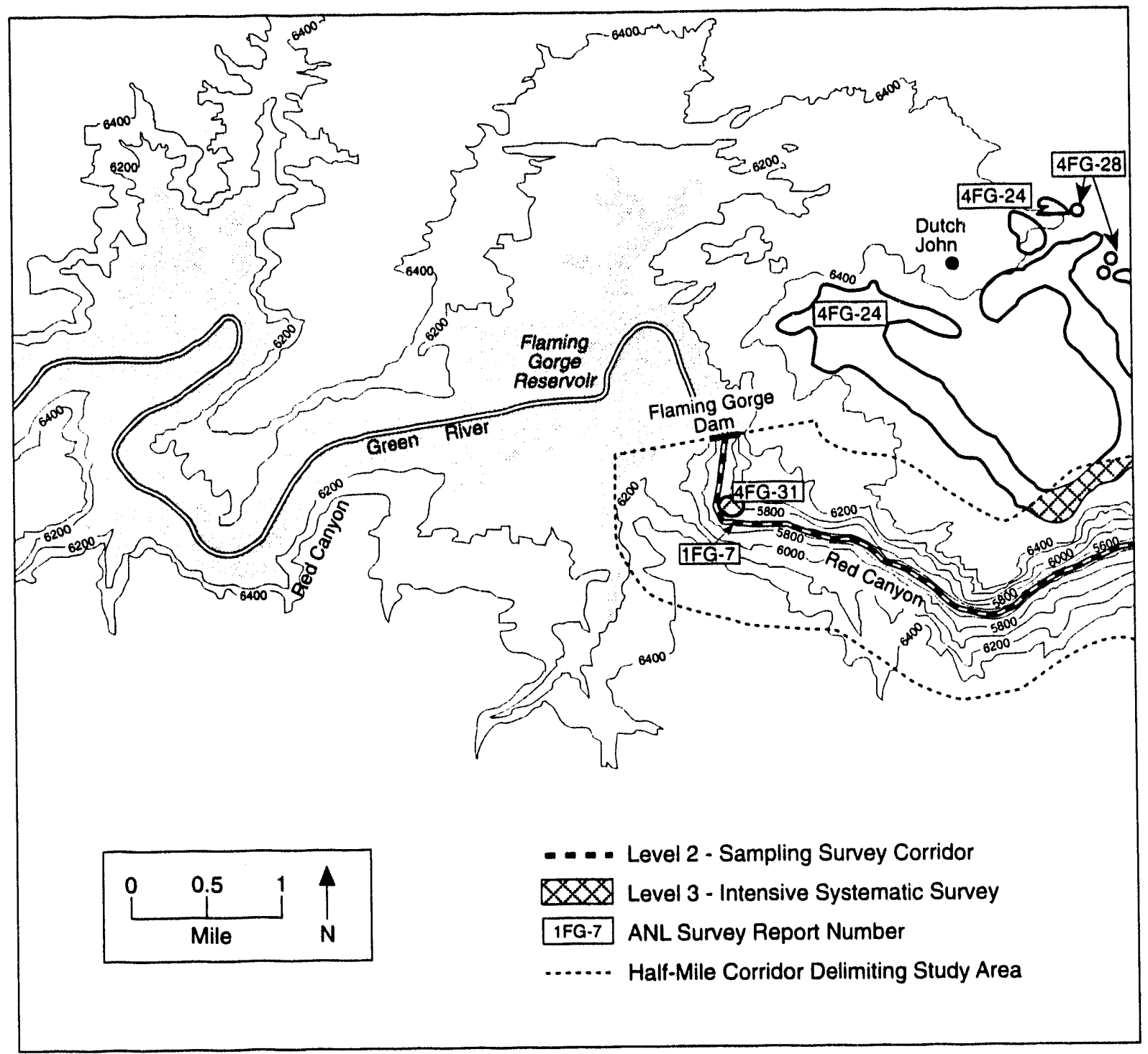

FIGURE 3 Previous Archaeological Surveys: Dutch John (Utah) 


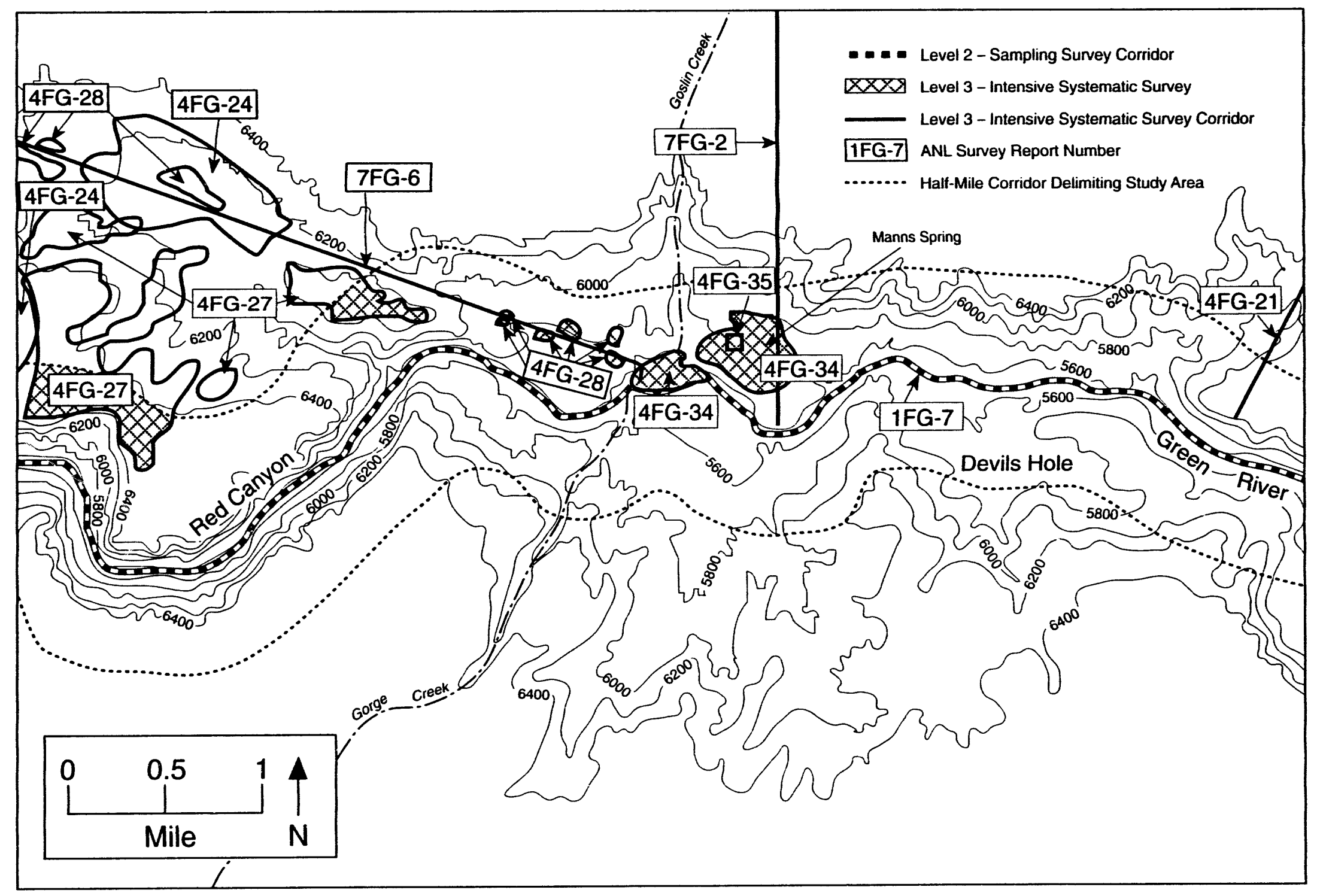

FIGURE 4 Previous Archaeological Surveys: Goslin Mountain (Utah) 


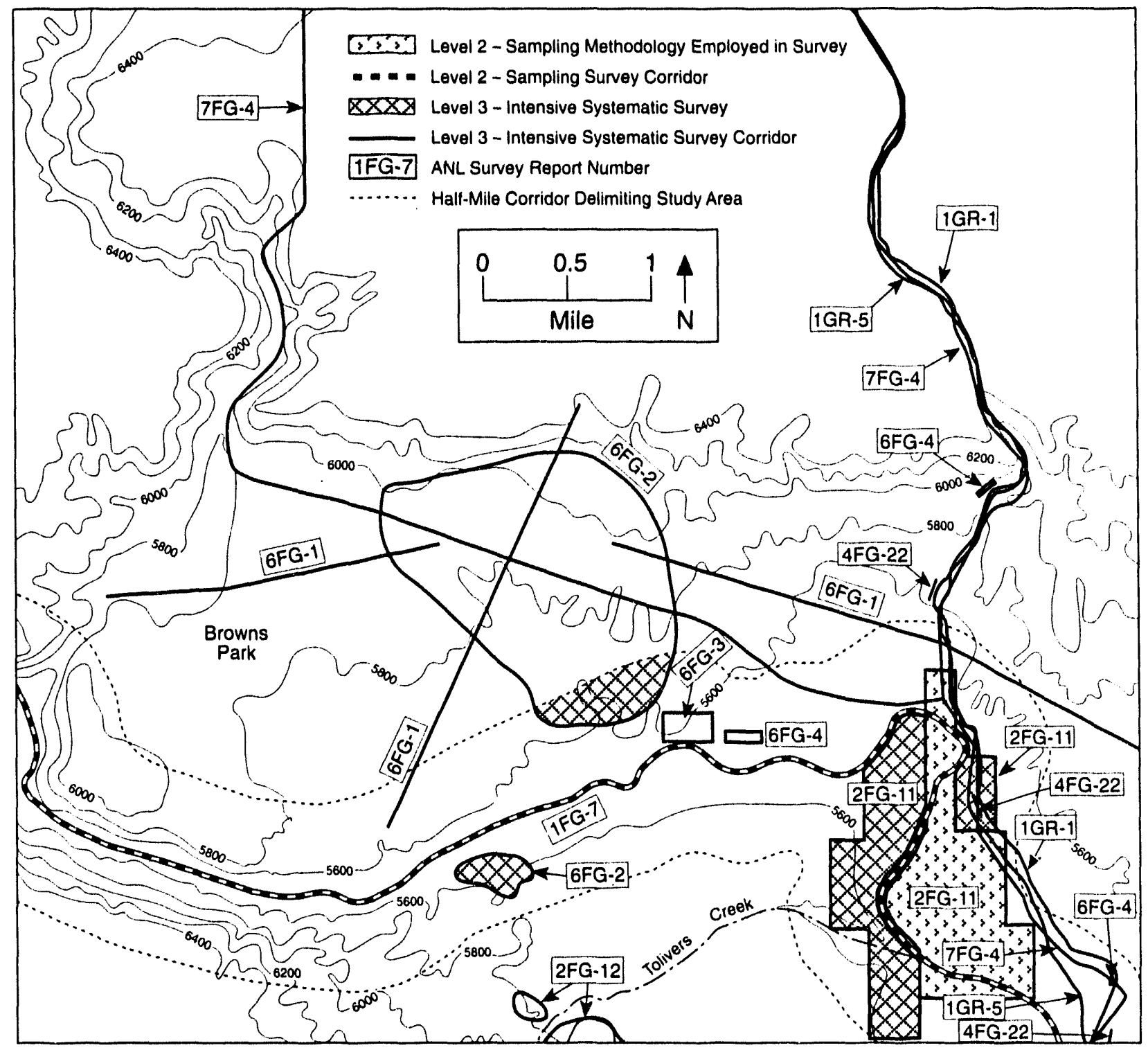

FIGURE 5 Previous Archaeological Surveys: Clay Basin (Utah) 


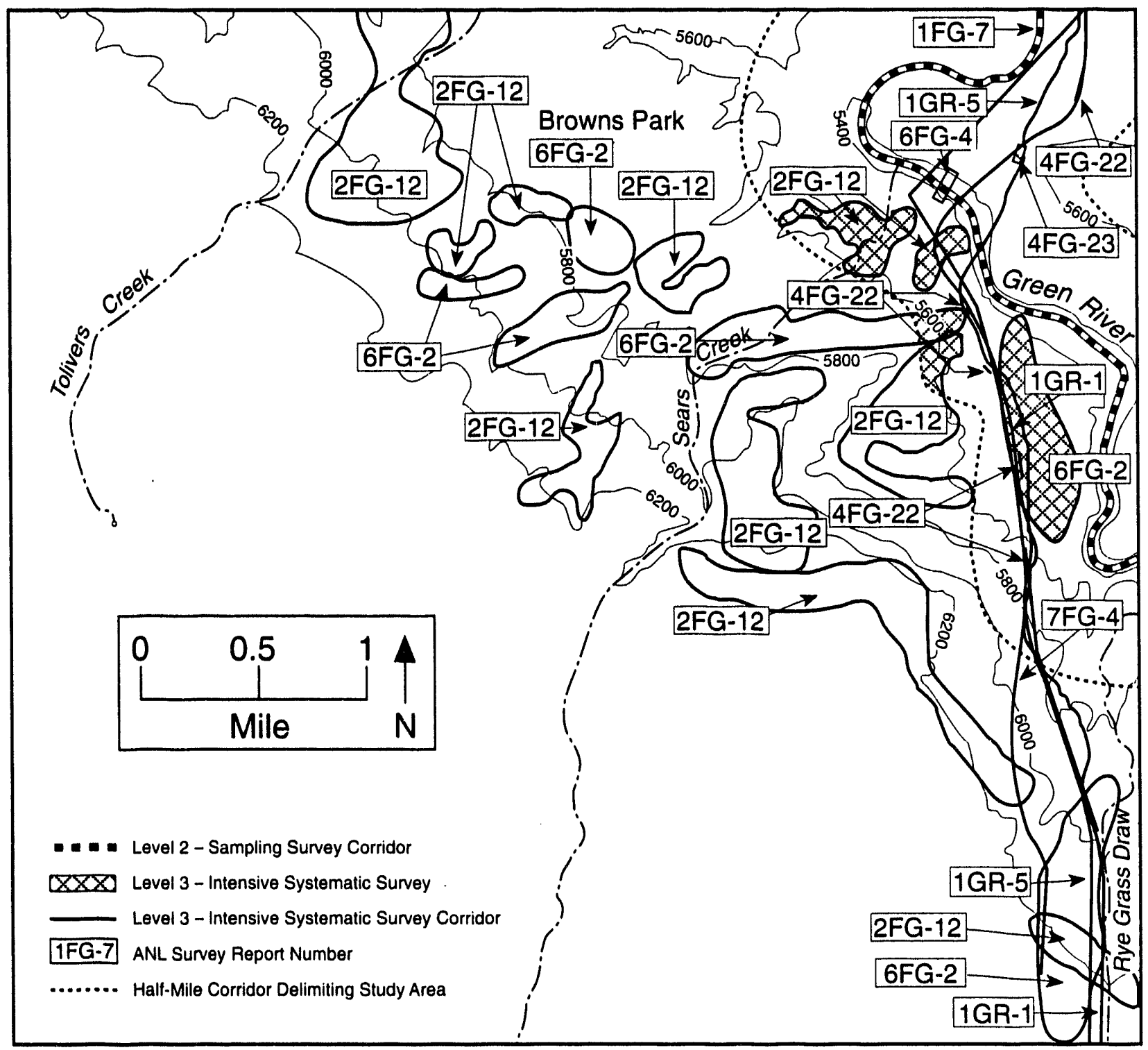

FIGURE 6 Previous Archaeological Surveys: Warren Draw (Utah) 


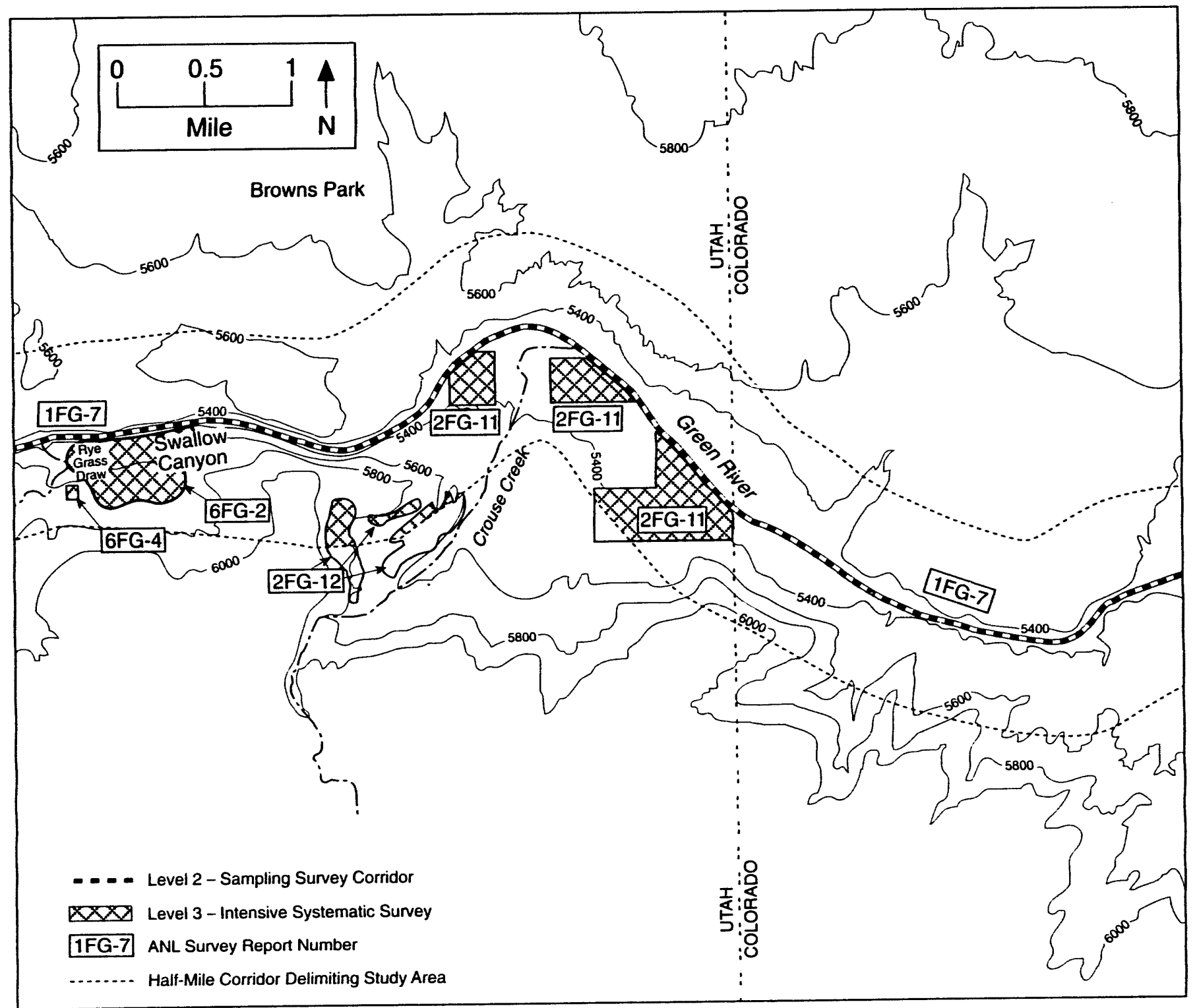

FIGURE 7 Previous Archaeological Surveys: Swallow Canyon (Utah, Colorado) 


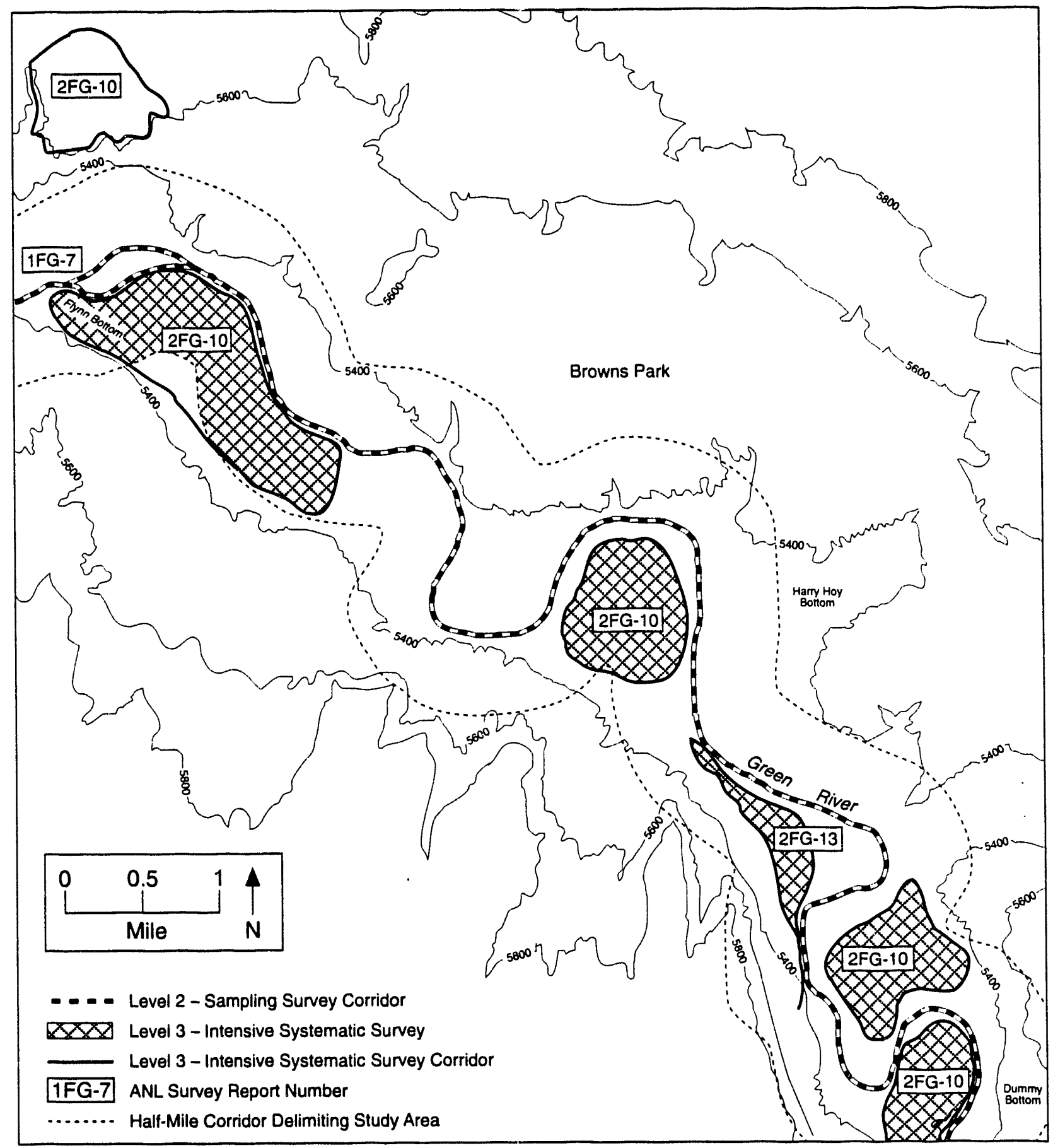

FIGURE 8 Previous Archaeological Surveys: Lodore School (Colorado) 


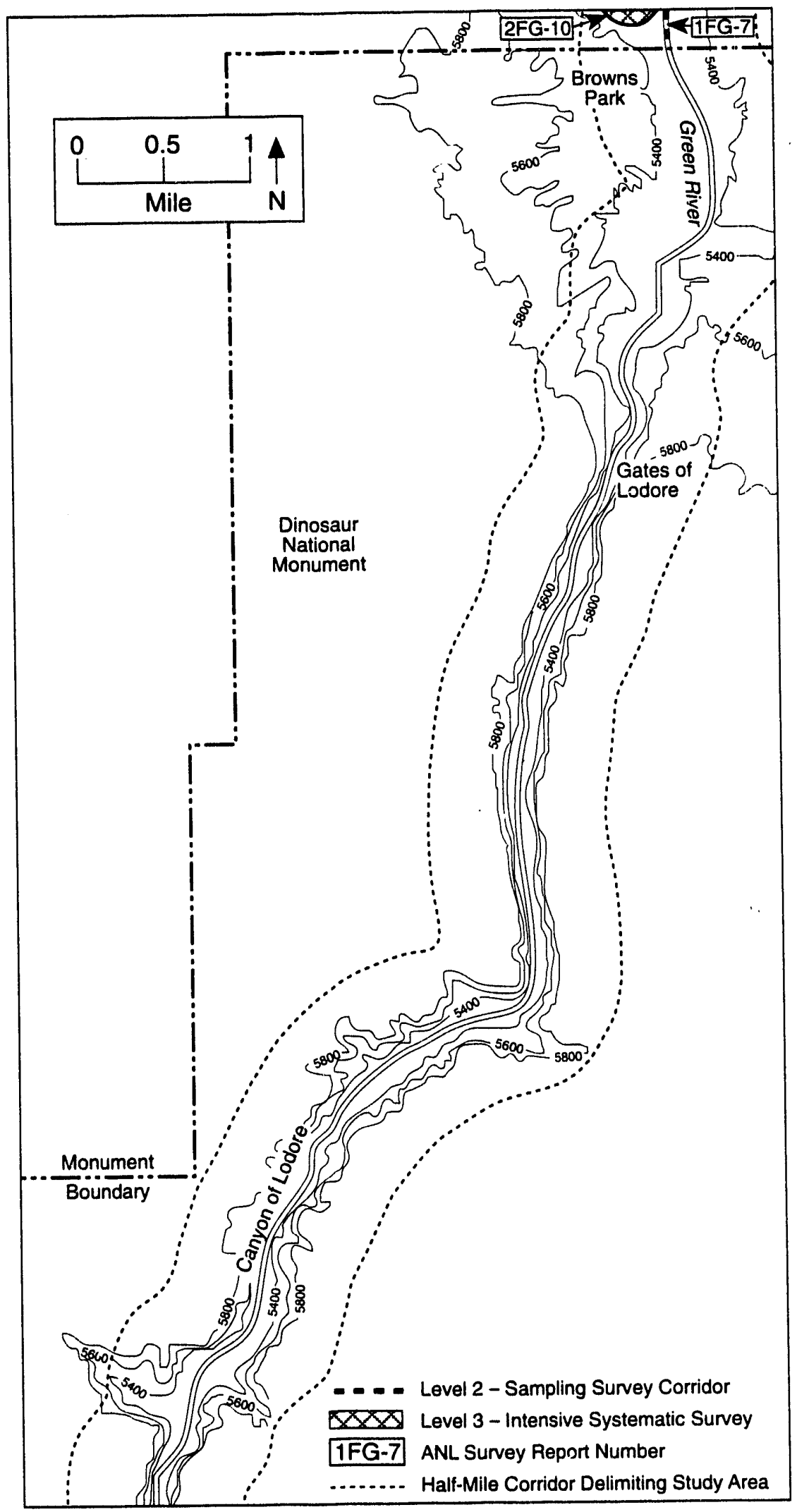

FIGURE 9 Previous Archaeological Surveys: Canyon of Lodore North (Colorado) 


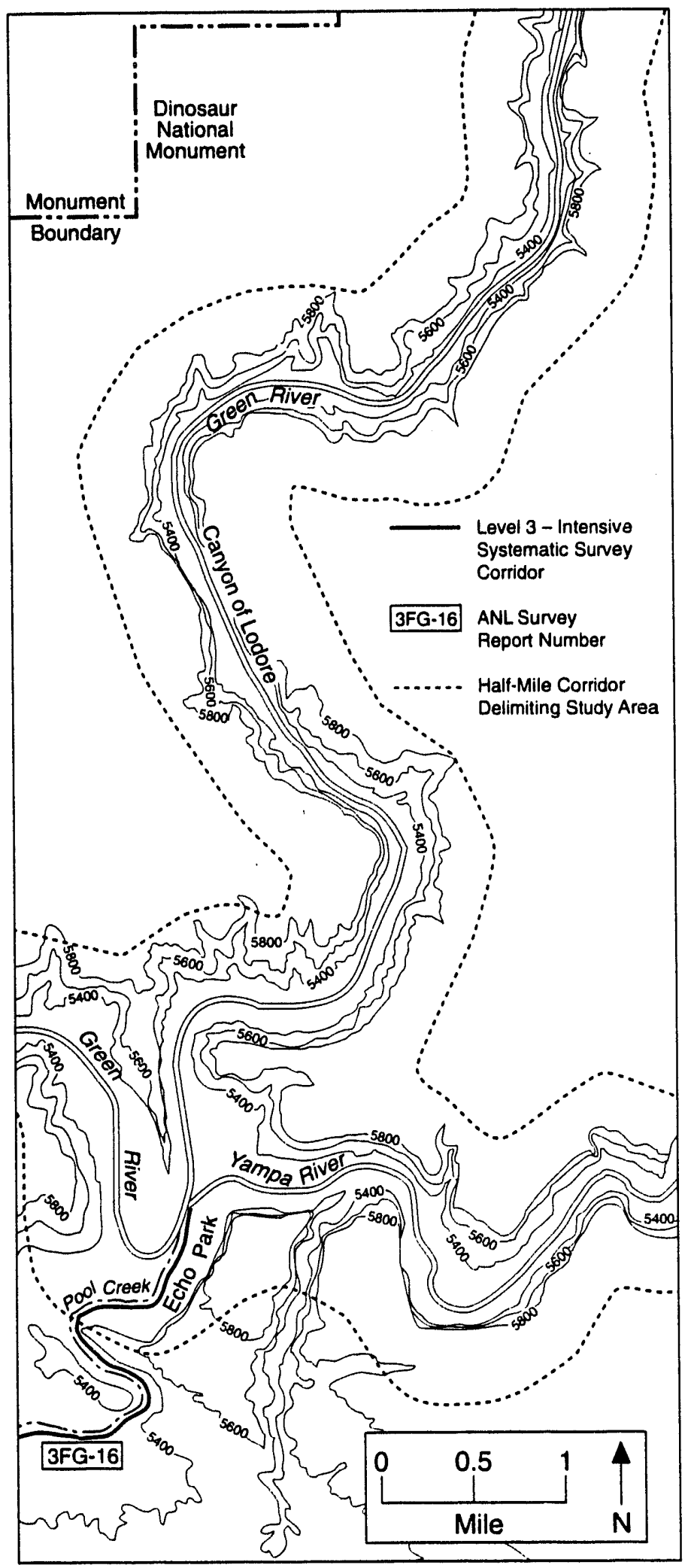

FIGURE 10 Previous Archaeological Surveys: Canyon of Lodore South (Colorado) 


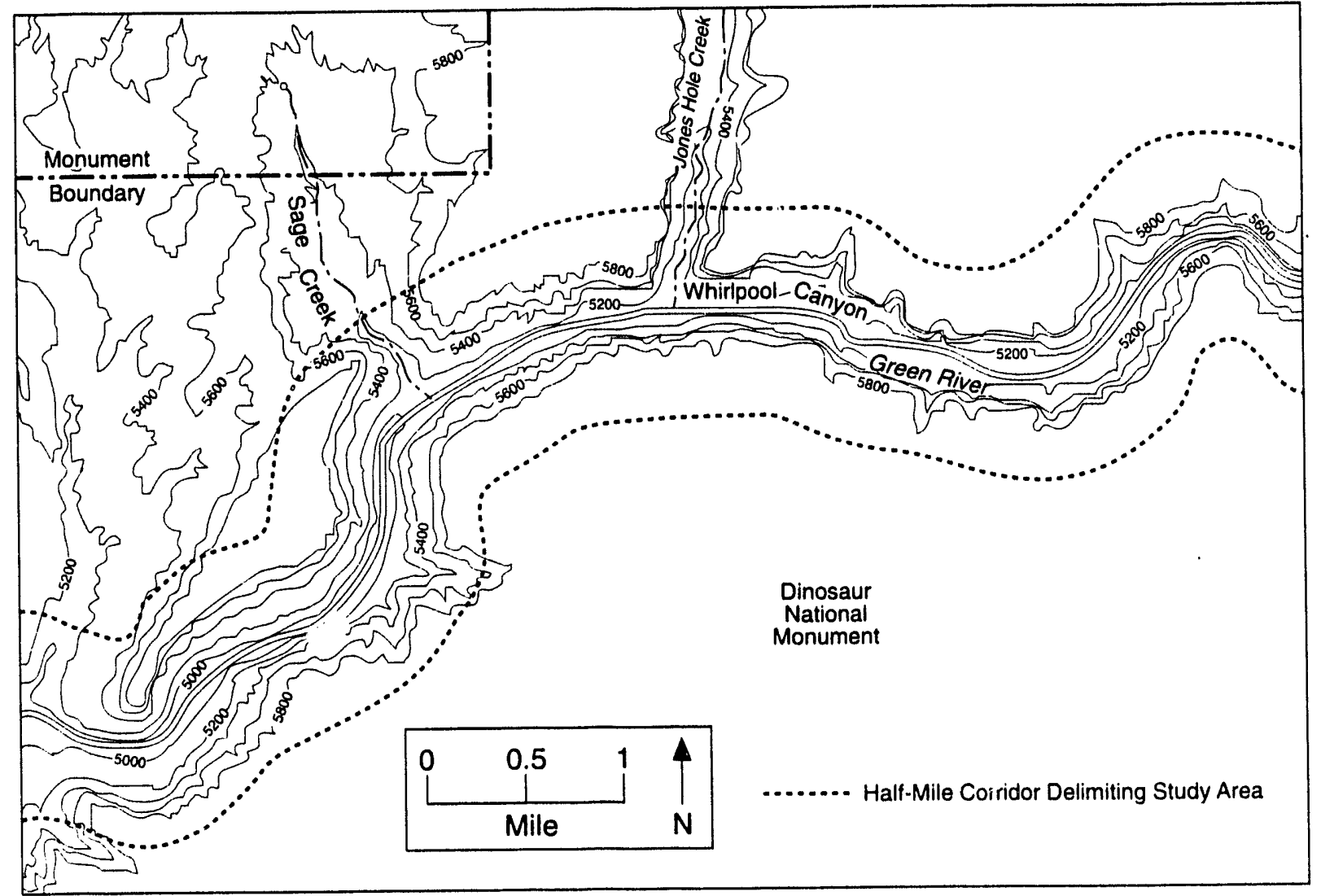

FIGURE 11 Previous Archaeological Surveys: Jones Hole (Colorado, Utah) 


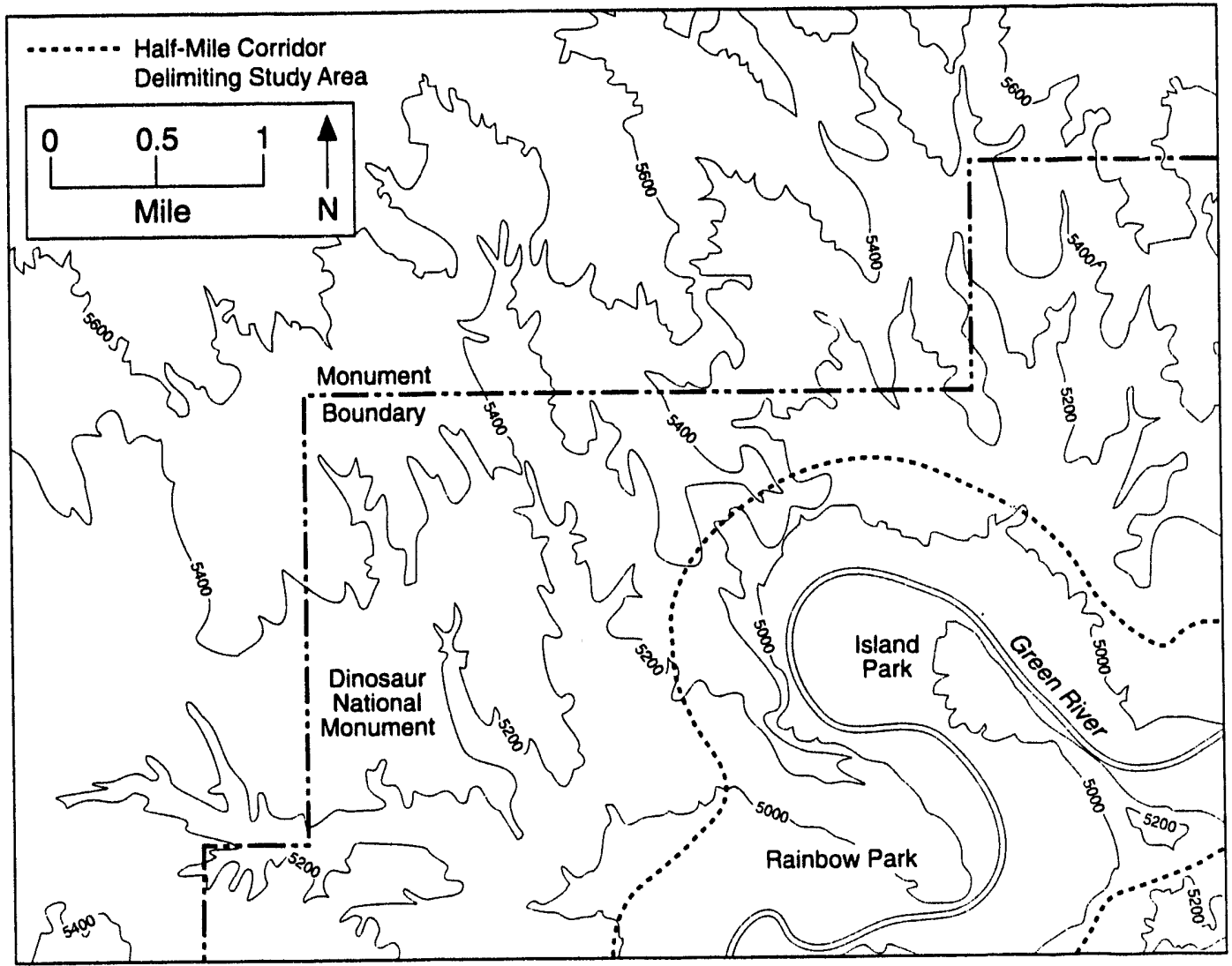

FIGURE 12 Previous Archaeological Surveys: Island Park (Utah) 


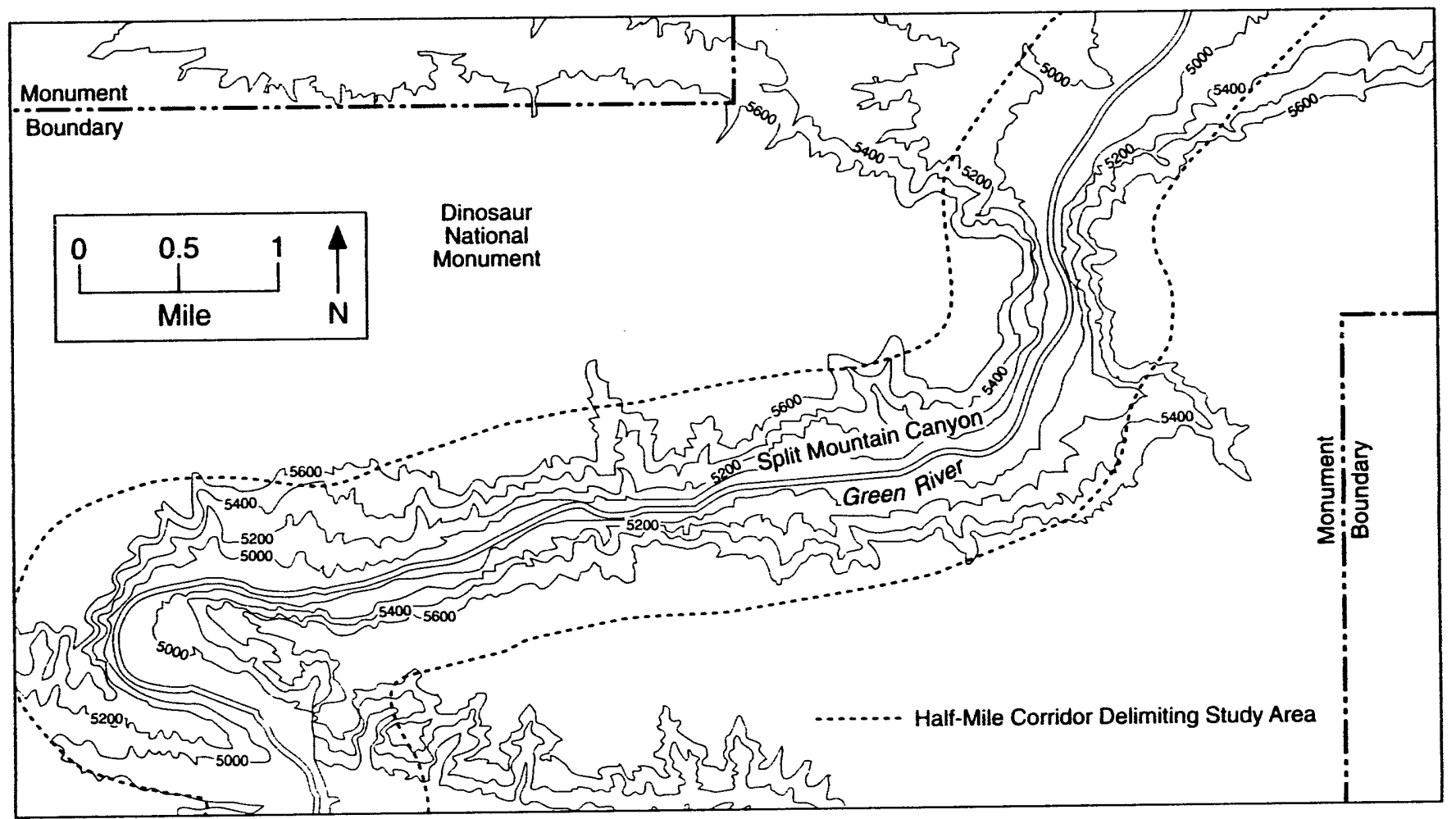

FIGURE 13 Previous Archaeological Surveys: Upper Half of Split Mountain and Dinosaur Quarry (Utah) Area 


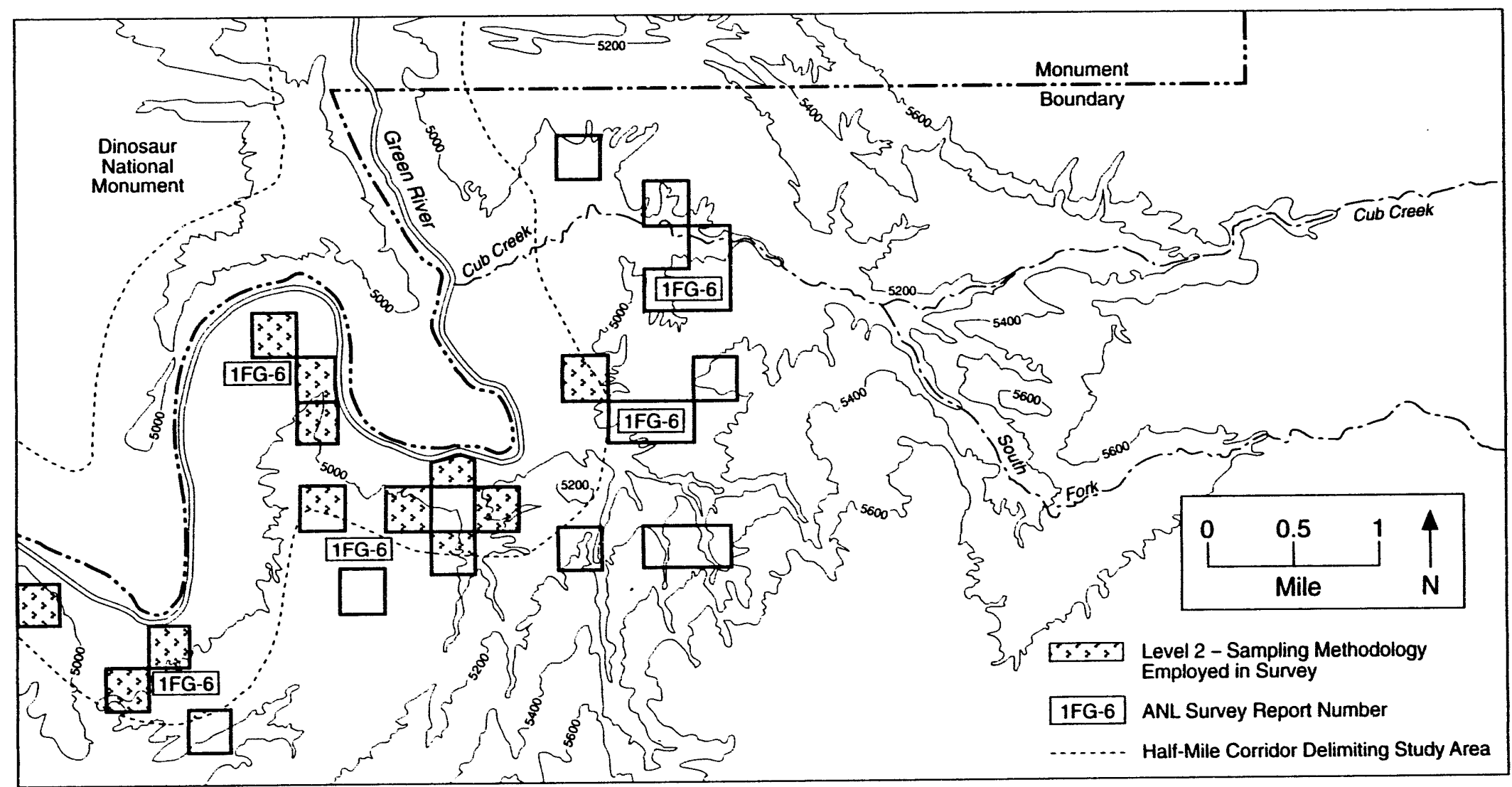

FIGURE 14 Previous Archaeological Surveys: Lower Half of Split Mountain and Dinosaur Quarry (Utah) Area 


\subsubsection{Reach 2: Yampa River Confluence to Cub Creek}

Reach 2 includes the area of the Green River between the Yampa River confluence in Colorado and Cub Creek, near the southern border of Dinosaur National Monument in Uintah County, Utah. Only three major surveys are reported to have been conducted within this, reach. One of the earliest surveys was an intuitive reconnaissance survey of $40 \%$ of Dinosaur National Park, which located 405 sites, some of which occur within the study area corridor; this survey was conducted with pedestrian transects in areas likely to contain archaeological sites (Breternitz 1965). The Split Mountain Cultural Study was a systematic sampling survey that covered $25 \%(2,030$ acres) of the 8,120-acre project area and recorded 26 sites and relocated 2 previously known sites (Holmer 1979). The third extensive survey within this reach of the Green River was the 194-acre Echo Park Road survey. The survey consisted of an intensive, comprehensive pedestrian survey of an 8-mi, 100- to 200-ft-wide road corridor. The survey relocated 7 known sites and recorded 26 newly discovered sites within the corridor (Truesdale et al. 1989). In addition, a major study of all known historic sites within Dinosaur National Monument was compiled by Mehls (1985). Although the total percentage of this reach that has been surveyed cannot be calculated with existing information, it is apparent that most of the corridor has been subject to an unsystematic survey (probably about 75\%), and at least one area (Echo Park) has been surveyed intensively (less than $1 \%$ ).

\subsection{RECORDED SITES}

A majority of the study area corridor has been subject to some type of archaeological survey (Section 2.5). As a result of these surveys, combined with incidental discoveries and known historical sites, a total of at least 107 prehistoric, 31 historic, and 6 combined prehistoric/historic sites are currently recorded within the study area. Five of these sites are listed on the NRHP, and 62 sites are considered eligible or potentially eligible for the NRHP. A complete list of these sites $^{3}$ is presented in Tables 3 (Reach 1) and 4 (Reach 2). In addition, known disturbances for individual sites are listed in Tables A.1 and A.2 of the Appendix.

Most of the prehistoric sites are surficial lithic scatters of varying density and area, which are sometimes associated with former hearths and other features; less common site types include rockshelters and petroglyphs. Prehistoric sites occur in a wide range of topographic settings, including the high floodplains, low and high terraces, stream confluences, and high bedrock surfaces. Overall, their distribution appears to be a function of topographic context and sampling; for example, Red Canyon (below Flaming Gorge Dam) has been surveyed but contains few archacological sites, presumably due to the lack of suitable site

3 Throughout this document, site identification numbers (I.D.) follow the format state number (numbered alphabetically), county code, and state site number - e.g., 42 DA40 refers to state 42 (Utah), Daggett County, site 40 in the state. Other county codes are GN, Gunnison County; MF, Moffat County; and UN, Uintah County. 
TABLE 3 Green River: Recorded Sites in Reach 1 (Flaming Gorge Dam to the Yampa River Confluence)

\begin{tabular}{|c|c|c|c|c|c|c|}
\hline Site I.D. & Prehistoric & Historic & Site Type & Structures & Features & NRHP Status \\
\hline 42DA6; BLM61 & Yes & $\begin{array}{l}\text { Euro-American } \\
1880-1897\end{array}$ & $\begin{array}{l}\text { Lithic scatter; } \\
\text { Dowd's Grave }\end{array}$ & Wood dugout & $\begin{array}{l}\text { Lithic scatter; } \\
3 \text { grave sites }\end{array}$ & Undetermined \\
\hline 42DA30 & $\begin{array}{l}\text { Late Prehis- } \\
\text { toric }\end{array}$ & No & Architectural & Stone slab structure & Clay roof & Undetermined \\
\hline 42DA40 & Yes & No & Campsite & Rock alignment & Lithic scatter & Undetermined \\
\hline 42DA52 & Yes & No & Campsite & None & $\begin{array}{l}6 \text { firepits; lithic } \\
\text { scatter }\end{array}$ & Potentially eligible \\
\hline 42DA53 & Yes & No & Campsite & None & $\begin{array}{l}\text { Hearths, } \\
\text { middens, fire- } \\
\text { cracked rock }\end{array}$ & Potentially eligible \\
\hline 42DA56 & Yes & No & Campsite & None & $\begin{array}{l}\text { Lithic scatter; } \\
\text { hearth }\end{array}$ & $\begin{array}{l}\text { Potentially not } \\
\text { eligible }\end{array}$ \\
\hline 42DA59 & Yes & No & Lithic & None & Lithic scatter & Undetermined \\
\hline 42DA61 & Yes & No & Campsite & None & Hearths & Eligible \\
\hline 42DA69 & Yes & No & Lithic workshop & None & Lithic scatter & Potentially eligible \\
\hline 42DA166; AS112 & Yes & No & Lithic & None & Lithic scatter & Undetermined \\
\hline 42DA167; AS113 & No & Yes & Habitation & Two log cabins & 4 concrete blocks & Potentially eligible \\
\hline 42DA168; AS114 & Yes & No & Lithic & None & $\begin{array}{l}\text { Lithic scatter; } \\
1 \text { Uinta Grey } \\
\text { Fremont sherd }\end{array}$ & Undetermined \\
\hline 42DA174; AS124 & Yes & No & Lithic & None & Lithic scatter & Undetermined \\
\hline 42DA175; AS125 & Yes & No & Lithic & None & Lithic scatter & Undetermined \\
\hline
\end{tabular}


TABLE 3 (Cont.)

\begin{tabular}{|c|c|c|c|c|c|c|}
\hline Site I.D. & Prehistoric & Historic & Site Type & Structures & Features & NRHP Status \\
\hline 42DA196; AS141 & Yes & No & Lithic & None & Lithic scatter & Undetermined \\
\hline 42DA202 & Yes & No & Lithic & None & $\begin{array}{l}\text { Lithic scatter; } \\
\text { hearth }\end{array}$ & Undetermined \\
\hline 42DA203 & Post Archaic & No & Campsite & None & $\begin{array}{l}\text { Lithic scatter; } \\
\text { charcoal }\end{array}$ & Undetermined \\
\hline 42DA204 & Yes & No & Lithic & None & Lithic scatter & $\begin{array}{l}\text { Potentially not } \\
\text { eligible }\end{array}$ \\
\hline 42DA211 & No & Yes & Dugout cabin & Cabin; cellar & None & Potentially eligible \\
\hline 42DA222; BLM199 & Yes & No & Lithic & None & Lithic scatter & $\begin{array}{l}\text { Potentially not } \\
\text { eligible }\end{array}$ \\
\hline $\begin{array}{l}\text { 42DA223; BLM200; } \\
\text { AS301 }\end{array}$ & Yes & No & Lithic & None & Lithic scatter & $\begin{array}{l}\text { Potentially not } \\
\text { eligible }\end{array}$ \\
\hline $\begin{array}{l}\text { 42DA224; BLM201; } \\
\text { AS302 }\end{array}$ & Yes & No & Lithic & None & Lithic scatter & $\begin{array}{l}\text { Potentially not } \\
\text { eligible }\end{array}$ \\
\hline 42DA226; BLM203 & Yes & No & $\begin{array}{l}\text { Campsite; } \\
\text { rockshelter }\end{array}$ & None & Lithic scatter & Un:ietermined \\
\hline 42DA227; BLM205 & No & Yes & $\begin{array}{l}\text { Placer mining } \\
\text { operation }\end{array}$ & $\begin{array}{l}\text { Canal; several } \\
\text { structures; retaining } \\
\text { walls }\end{array}$ & Trash scatter & Potentially eligible \\
\hline 42DA228; BLM216 & Yes & No & Lithic & None & Lithic scatter & Undetermined \\
\hline 42DA241; BLM219 & Yes & No & Lithic & None & Lithic scatter & Undetermined \\
\hline 42DA275; BLM202 & Yes & No & Lithic & None & Lithic scatter & $\begin{array}{l}\text { Potentially not } \\
\text { eligible }\end{array}$ \\
\hline
\end{tabular}


TABLE 3 (Cont.)

\begin{tabular}{|c|c|c|c|c|c|c|}
\hline Site I.D. & Prehistoric & Historic & Site Type & Structures & Features & NRHP Status \\
\hline 42DA332; BLM206 & Yes & Yes & $\begin{array}{l}\text { Prehistoric lithic } \\
\text { scatter; historic } \\
\text { corral }\end{array}$ & None & Lithic scatter & Potentially eligible \\
\hline $\begin{array}{l}\text { 42DA333; BLM207; } \\
\text { AS303 }\end{array}$ & No & Late $1800 \mathrm{~s}$ & $\begin{array}{l}\text { Wagon road and } \\
\text { fence remnant }\end{array}$ & Fence & Wagon road & Potentially eligible \\
\hline $\begin{array}{l}\text { 42DA334; BLM208; } \\
\text { AS304 }\end{array}$ & Yes & No & Lithic & None & $\begin{array}{l}\text { Lithic scatter; } \\
\text { mano }\end{array}$ & $\begin{array}{l}\text { Potentially not } \\
\text { eligible }\end{array}$ \\
\hline 42DA335; BLM209 & Yes & No & Campsite & None & Lithic scatter & Not eligible \\
\hline 42DA336; BLM210 & Yes & Yes & $\begin{array}{l}\text { Rockshelter; } \\
\text { historic hearth }\end{array}$ & None & $\begin{array}{l}\text { Lithic scatter; } \\
\text { hearth }\end{array}$ & Potentially eligible \\
\hline 42DA337; BLM211 & No & Yes; Pre-1900 & Saloon & Rock foundations & Trash scatter & Potentially eligible \\
\hline 42DA338; BLM213 & No & Euro-American & Irrigation canal & $\begin{array}{l}\text { Flume support for } \\
\text { irrigation }\end{array}$ & Wagon box & Potentially eligible \\
\hline 42DA339 & Yes & No & Lithic & None & Lithic scatter & Not eligible \\
\hline 42DA342 & No & Euro-American & $\begin{array}{l}\text { Bridge and } \\
\text { dugouts }\end{array}$ & Bridge & $\begin{array}{l}\text { Dugouts; } \\
\text { ceramic; glass }\end{array}$ & Potentially eligible \\
\hline 42DA387 & Yes & No & Lithic & None & Lithic scatter & Potentially eligible \\
\hline 42DA388 & Yes & No & Lithic & None & $\begin{array}{l}\text { Lithic scatter; } \\
\text { midden }\end{array}$ & Potentially eligible \\
\hline 42DA393 & Yes & No & Campsite & None & $\begin{array}{l}\text { Lithic scatter; } \\
\text { charcoal deposits }\end{array}$ & Eligible \\
\hline 42DA394 & No & Yes & Irrigation ditch & None & None & Undetermined \\
\hline 42DA395 & No & Yes & Stagecoach route & None & None & Potentially eligible \\
\hline
\end{tabular}


TABLE 3 (Cont.)

\begin{tabular}{|c|c|c|c|c|c|c|}
\hline Site I.D. & Prehistoric & Historic & Site Type & Structures & Features & NRHP Status \\
\hline 42DA402 & Yes & No & Campsite & None & $\begin{array}{l}\text { Lithic scatter; } \\
\text { groundstone; } \\
\text { possible } \\
\text { subsurface }\end{array}$ & Potentially eligible \\
\hline 42DA409 & Archaic & No & Campsite & None & Hearths & Potentially eligible \\
\hline 42DA410 & Yes & No & Lithic & None & Lithic scatter & $\begin{array}{l}\text { Potentially not } \\
\text { eligible }\end{array}$ \\
\hline 42DA411 & Yes & No & Lithic quarry & None & Lithic scatter & $\begin{array}{l}\text { Potentially not } \\
\text { eligible }\end{array}$ \\
\hline 42DA412 & Yes & No & Campsite & None & $\begin{array}{l}\text { Hearth; midden } \\
\text { areas }\end{array}$ & Potentially eligible \\
\hline 42DA413 & Yes & No & Lithic & None & Lithic scatter & $\begin{array}{l}\text { Potentially not } \\
\text { eligible }\end{array}$ \\
\hline 42DA414 & Yes & No & Campsite & None & $\begin{array}{l}\text { Several possible } \\
\text { hearths }\end{array}$ & Potentially eligible \\
\hline 42DA415 & Yes & No & Campsite & None & $\begin{array}{l}\text { Hearth; fire- } \\
\text { cracked rock }\end{array}$ & Potentially eligible \\
\hline 42DA416 & Yes & No & Rockshelter & None & Midden area & Potentially eligible \\
\hline 42DA417 & Yes & No & Campsite & None & $\begin{array}{l}\text { At least } \\
4 \text { hearths }\end{array}$ & Potentially eligible \\
\hline 42DA419 & Yes & No & Lithic & None & Lithic scatter & $\begin{array}{l}\text { Potentially not } \\
\text { eligible }\end{array}$ \\
\hline 42DA420 & Post Archaic & No & Campsite & None & $\begin{array}{l}\text { Lithic scatter; } \\
6 \text { hearths }\end{array}$ & Potentially eligible \\
\hline
\end{tabular}


TABLE 3 (Cont.)

\begin{tabular}{|c|c|c|c|c|c|c|}
\hline Site I.D. & Prehistoric & Historic & Site Type & Structures & Features & NRHP Status \\
\hline 42DA436 & Yes & No & Campsite & None & $\begin{array}{l}\text { Lithic scatter; } \\
\text { slab hearth }\end{array}$ & Potentially eligible \\
\hline 42DA438 & Yes & No & Campsite & None & $\begin{array}{l}\text { Lithic scatter; } \\
\text { hearths; middens }\end{array}$ & Potentially eligible \\
\hline 42DA485 & Yes & No & $\begin{array}{l}\text { Campsite; lithic } \\
\text { workshop }\end{array}$ & None & $\begin{array}{l}\text { Hearth; charcoal; } \\
\text { lithic scatter }\end{array}$ & Potentially eligible \\
\hline 42DA486 & Yes & No & Lithic quarry & None & Lithic scatter & $\begin{array}{l}\text { Potentially not } \\
\text { eligible }\end{array}$ \\
\hline 42DA487 & Yes & No & Lithic & None & Lithic scatter & $\begin{array}{l}\text { Potentially not } \\
\text { eligible }\end{array}$ \\
\hline 42DA488 & Fremont & No & $\begin{array}{l}\text { Lithic and } \\
\text { ceramic scatter }\end{array}$ & None & $\begin{array}{l}\text { Lithic scatter; } \\
\text { ceramic scatter }\end{array}$ & Undetermined \\
\hline 42DA489 & Late Archaic & No & Lithic & None & Lithic scatter & $\begin{array}{l}\text { Potentially not } \\
\text { eligible }\end{array}$ \\
\hline $\begin{array}{l}\text { 5MF62; Confluence } \\
\text { Site }\end{array}$ & Yes & No & Lithic & None & $\begin{array}{l}\text { Lithic scatter; } \\
\text { manos }\end{array}$ & Undetermined \\
\hline 5MF242 & Yes & No & Lithic & None & Lithic scatter & $\begin{array}{l}\text { Potentially not } \\
\text { eligible }\end{array}$ \\
\hline 5MF248 & Yes & No & Campsite & None & $\begin{array}{l}\text { Lithic scatter; } \\
\text { hearth; ash- } \\
\text { charcoal }\end{array}$ & Potentially eligible \\
\hline 5MF249 & Unknown & Unknown & No data & No data & No data & Undetermined \\
\hline $\begin{array}{l}\text { 5MF605; Fort Davy } \\
\text { Crockett }\end{array}$ & No & 19th century & Fur trading post & None & None specified & Listed \\
\hline
\end{tabular}


TABLE 3 (Cont.)

\begin{tabular}{|c|c|c|c|c|c|c|}
\hline Site I.D. & Prehistoric & Historic & Site Type & Structures & Features & NRHP Status \\
\hline 5MF688; Metate Rock & Fremont & No & Petroglyph panel & None & $\begin{array}{l}\text { Bedrock mortar; } \\
\text { metate; petro- } \\
\text { glyphs }\end{array}$ & Eligible \\
\hline $\begin{array}{l}\text { 5MF840; Flynn } \\
\text { Bottom }\end{array}$ & Protohistoric & No & Campsite & None & $\begin{array}{l}\text { Lithic scatter; } \\
\text { tepee rings; } \\
\text { hearths }\end{array}$ & Potentially eligible \\
\hline $\begin{array}{l}\text { 5MF841; Carr Bottom } \\
\text { Site }\end{array}$ & Protohistoric & No & Lithic workshop & None & $\begin{array}{l}\text { Lithic scatter; } \\
\text { manos and } \\
\text { metates }\end{array}$ & Potentially eligible \\
\hline $5 \mathrm{MF} 859$ & No & Yes & Round corral & Corral & Logs & Undetermined \\
\hline $\begin{array}{l}\text { 5MF1127; Lodore } \\
\text { School }\end{array}$ & No & Yes & $\begin{array}{l}\text { Old Lodore } \\
\text { School }\end{array}$ & $\begin{array}{l}\text { One-room } \\
\text { schoolhouse }\end{array}$ & $\begin{array}{l}\text { Wood frame, } \\
\text { front gable, } \\
\text { lumber }\end{array}$ & Listed \\
\hline 5MF1228 & Yes & No & Lithic & None & Lithic scatter & Undetermined \\
\hline $5 M F 1229$ & No & Yes & Campsite & None & Trash scatter & Not eligible \\
\hline 5MF1230 & Yes & No & Lithic & None & Lithic scatter & Undetermined \\
\hline $\begin{array}{l}\text { 5MF1231; Mike Flynn } \\
\text { Cabin }\end{array}$ & No & 19th century & Log cabin & Cabin & Irrigation canal & Eligible \\
\hline $\begin{array}{l}\text { 5MF1232; James } \\
\text { Warren Cabin }\end{array}$ & No & 19th century & Log cabin & Cabin & None specified & Eligible \\
\hline 5MF1233 & No & 19th century & Trash dump & None & Trash dump & Potentially eligible \\
\hline 5MF1234 & No & Yes & Architectural & $\begin{array}{l}\text { Animal shed and } \\
\text { cable ferry structure }\end{array}$ & None specified & Eligible \\
\hline $\begin{array}{l}\text { 5MF1235; Larry } \\
\text { Curtin Cabin }\end{array}$ & No & Yes & Ranch & $\begin{array}{l}\text { Log ranchhouse; } \\
\text { outbuildings }\end{array}$ & None specified & Potentially eligible \\
\hline
\end{tabular}


TABLE 3 (Cont.)

\begin{tabular}{|c|c|c|c|c|c|c|}
\hline Site I.D. & Prehistoric & Historic & Site Type & Structures & Features & NRHP Status \\
\hline 5MF1236 & No & ca. 1911 & Log cabin & Stone fireplace & None specified & Potentially eligible \\
\hline $\begin{array}{l}\text { 5MF1237; Joe Herrera } \\
\text { House }\end{array}$ & No & 19th century & Log cabin & $\begin{array}{l}2 \text { chimneys; house } \\
\text { foundations }\end{array}$ & None specified & Potentially eligible \\
\hline 5MF1238 & Yes & No & Lithic & None & Lithic scatter & Not eligible \\
\hline 5MF1398; Carr Place & No & Yes & $\begin{array}{l}\text { Homestead/ } \\
\text { ranch }\end{array}$ & No data & No data & Potentially eligible \\
\hline $5 \mathrm{MF} 1752$ & Archaic & No & Isolated find & None & Projectile point & $\begin{array}{l}\text { Potentially not } \\
\text { eligible }\end{array}$ \\
\hline $\begin{array}{l}\text { 5MF2357; Wade/ } \\
\text { Curtis Cabin }\end{array}$ & No & Yes & $\begin{array}{l}\text { Upper Wade/ } \\
\text { Curtis Cabin }\end{array}$ & Cabin & $\begin{array}{l}\text { Concrete } \\
\text { foundation }\end{array}$ & Listed \\
\hline 5MF2388 & No & Yes & USGS camp & None & $\begin{array}{l}\text { Tent floors; } \\
\text { dugout; stakes }\end{array}$ & Not eligible \\
\hline $\begin{array}{l}\text { 5MF2404; Wade/ } \\
\text { Curtis Cabin }\end{array}$ & No & Yes & $\begin{array}{l}\text { Lower Wade/ } \\
\text { Curtis Cabin }\end{array}$ & Cabin & Concrete slab & Not eligible \\
\hline 5MF2406 & No & $1890 \mathrm{~s}$ & Outlaw trail & None & Trail & $\begin{array}{l}\text { Officially not } \\
\text { eligible }\end{array}$ \\
\hline 5MF2656 & $\begin{array}{l}\text { Late Prehis- } \\
\text { toric }\end{array}$ & No & Lithic & Adobe granaries & Lithic scatter & Undetermined \\
\hline 5MF2746 & Yes & No & Campsite & None & $\begin{array}{l}\text { Lithics; fire- } \\
\text { cracked rock; } \\
\text { manos; metates }\end{array}$ & Eligible \\
\hline $\begin{array}{l}\text { BLM288; John Jarvie } \\
\text { Ranch }\end{array}$ & No & $\begin{array}{l}\text { Late } 19 \text { th, early } \\
\text { 20th century }\end{array}$ & Settlement & Several structures & $\begin{array}{l}4 \text { graves; ferry; } \\
\text { irrigation ditches }\end{array}$ & Listed \\
\hline Doc Parson's Cabin & No & Yes & Cabin & Cabin & None & Listed \\
\hline
\end{tabular}


TABLE 4 Green River: Recorded Sites in Reach 2 (Yampa River Confluence to Cub Creek)

\begin{tabular}{|c|c|c|c|c|c|c|}
\hline Site I.D. & Prehistoric & Historic & Site Type & Structures & Features & NRHP Status \\
\hline $\begin{array}{l}\text { 42UN60; } \\
\text { Moonshine Rapids }\end{array}$ & Late Fremont & No & Cave; rockshelter & None & $\begin{array}{l}\text { Petroglyphs; ceramic } \\
\text { scatter; f.unal } \\
\text { remains; metates }\end{array}$ & Undetermined \\
\hline 42UN61 & Yes & No & Lithic & None & Lithic scatter & Undetermined \\
\hline 42UN242 & Yes & No & Campsite & None & Lithic scatter & Undetermined \\
\hline 42UN253; DNM91 & Yes & No & $\begin{array}{l}\text { Lithic chipping } \\
\text { station }\end{array}$ & None & Lithic scatter & Undetermined \\
\hline 42UN254; DNM93 & Yes & No & $\begin{array}{l}\text { Lithic chipping } \\
\text { station }\end{array}$ & None & Lithic scatter & Undetermined \\
\hline 42UN256 & Yes & No & Lithic & None & Lithic scatter & Undetermined \\
\hline 42UN258; DNM97 & Yes & No & Campsite & None & Lithic scatter; firepits & Potentially eligible \\
\hline 42UN259; DNM98 & Yes & No & Campsite & None & $\begin{array}{l}\text { Tipi rings; hearths; } \\
\text { lithic scatter }\end{array}$ & Potentially eligible \\
\hline 42UN260; DNM99 & Yes & No & Lithic & None & Lithic scatter & Potentially eligible \\
\hline 42UN262; DNM101 & Yes & No & Lithic scatter & None & Lithic scatter & Potentially eligible \\
\hline 42UN265; DNM104 & Yes & No & Campsite & None & Lithic scatter & Potentially eligible \\
\hline 42UN267; DNM106 & Yes & No & Lithic & None & Lithic scatter & Potentially eligible \\
\hline 42UN268; DNM107 & Yes & No & Campsite & None & Lithic scatter & Potentially eligible \\
\hline 42UN269; DNM108 & Yes & No & Campsite & None & Lithic scatter; firepits & Potentially eligible \\
\hline 42UN270; DNM109 & Yes & No & Lithic & None & Lithic scatter & Potentially eligible \\
\hline 42UN271; DNM110 & Yes & No & Lithic & None & Lithic scatter & Potentially eligible \\
\hline
\end{tabular}


TABLE 4 (Cont.)

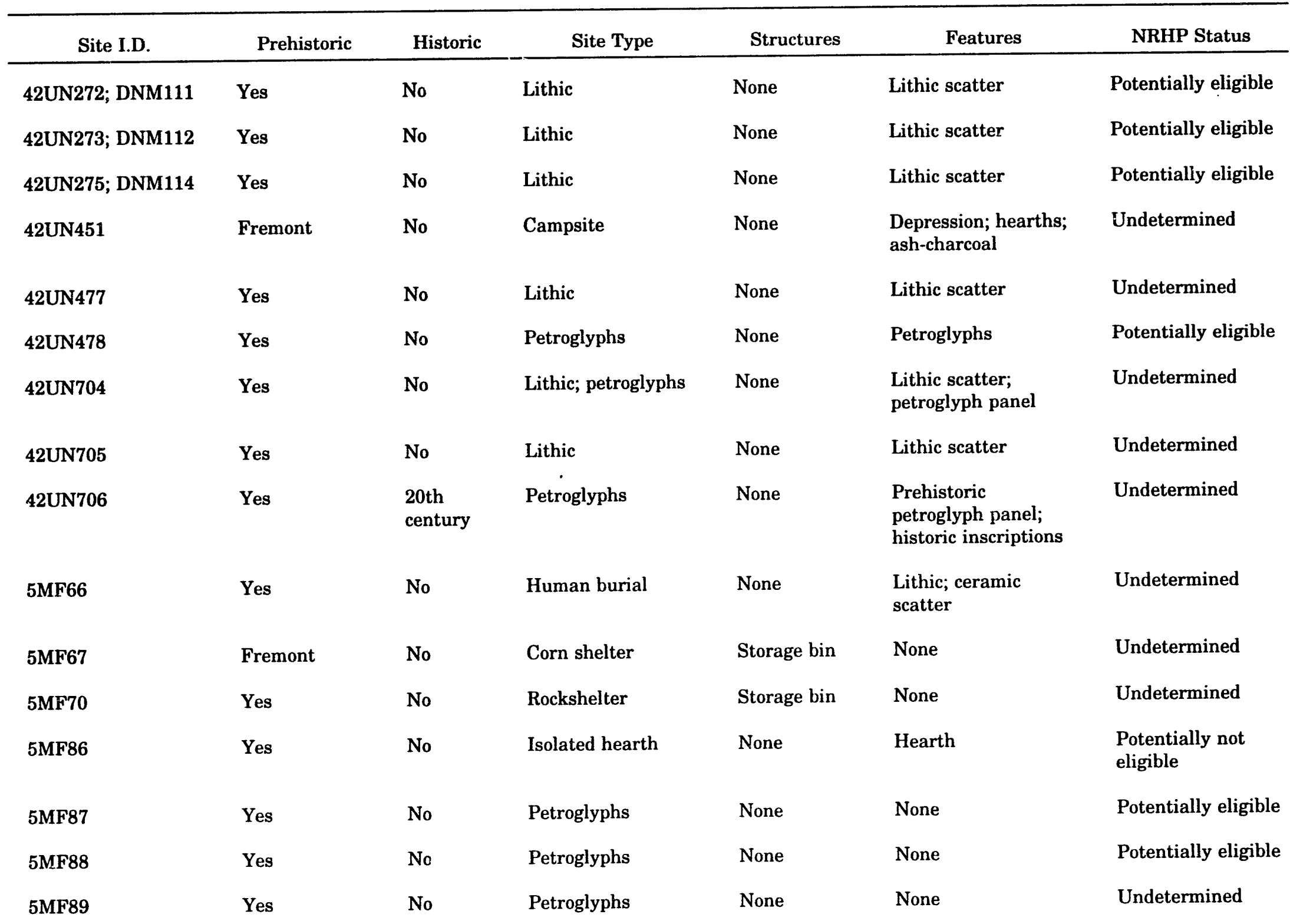


TABLE 4 (Cont.)

\begin{tabular}{|c|c|c|c|c|c|c|}
\hline Site I.D. & Prehistoric & Historic & Site Type & Structures & Features & NRHP Status \\
\hline 5MF90 & Yes & No & Rockshelter & None & None & Undetermined \\
\hline 5MF91 & Yes & No & Rockshelter; cave & None & $\begin{array}{l}\text { Lithic; ceramic } \\
\text { scatter; manos }\end{array}$ & Undetermined \\
\hline 5MF92 & Yes & No & Rockshelter & None & None & $\begin{array}{l}\text { Potentially not } \\
\text { eligible }\end{array}$ \\
\hline 5MF139 & Yes & No & Lithic & None & Lithic scatter & Field not eligible \\
\hline 5MF140 & Yes & No & Lithic & None & Lithic scatter & Field not eligible \\
\hline 5MF141 & Yes & No & Rock art panel & None & None & Field not eligible \\
\hline 5MF142 & Yes & No & Lithic & None & Lithic scatter & Field not eligible \\
\hline 5MF156 & Yes & Unknown & Rockshelter & None & None & Undetermined \\
\hline 5MF157 & Yes & No & Petroglyphs & None & None & Potentially eligible \\
\hline 5MF169 & Yes & No & Lithic & None & Lithic scatter & Undetermined \\
\hline 5MF170 & Yes & No & Lithic & None & Lithic scatter & $\begin{array}{l}\text { Potentially not } \\
\text { eligible }\end{array}$ \\
\hline 5MF171 & Yes & No & Lithic & None & Lithic scatter & $\begin{array}{l}\text { Potentially not } \\
\text { eligible }\end{array}$ \\
\hline 5MF172 & Yes & No & Lithic & None & Lithic scatter & $\begin{array}{l}\text { Potentially not } \\
\text { eligible }\end{array}$ \\
\hline 5MF173 & Yes & No & Lithic & None & Lithic scatter & $\begin{array}{l}\text { Potentially not } \\
\text { eligible }\end{array}$ \\
\hline 5MF2119 & Yes & No & Lithic & None & Lithic scatter & Undetermined \\
\hline
\end{tabular}


TABLE 4 (Cont.)

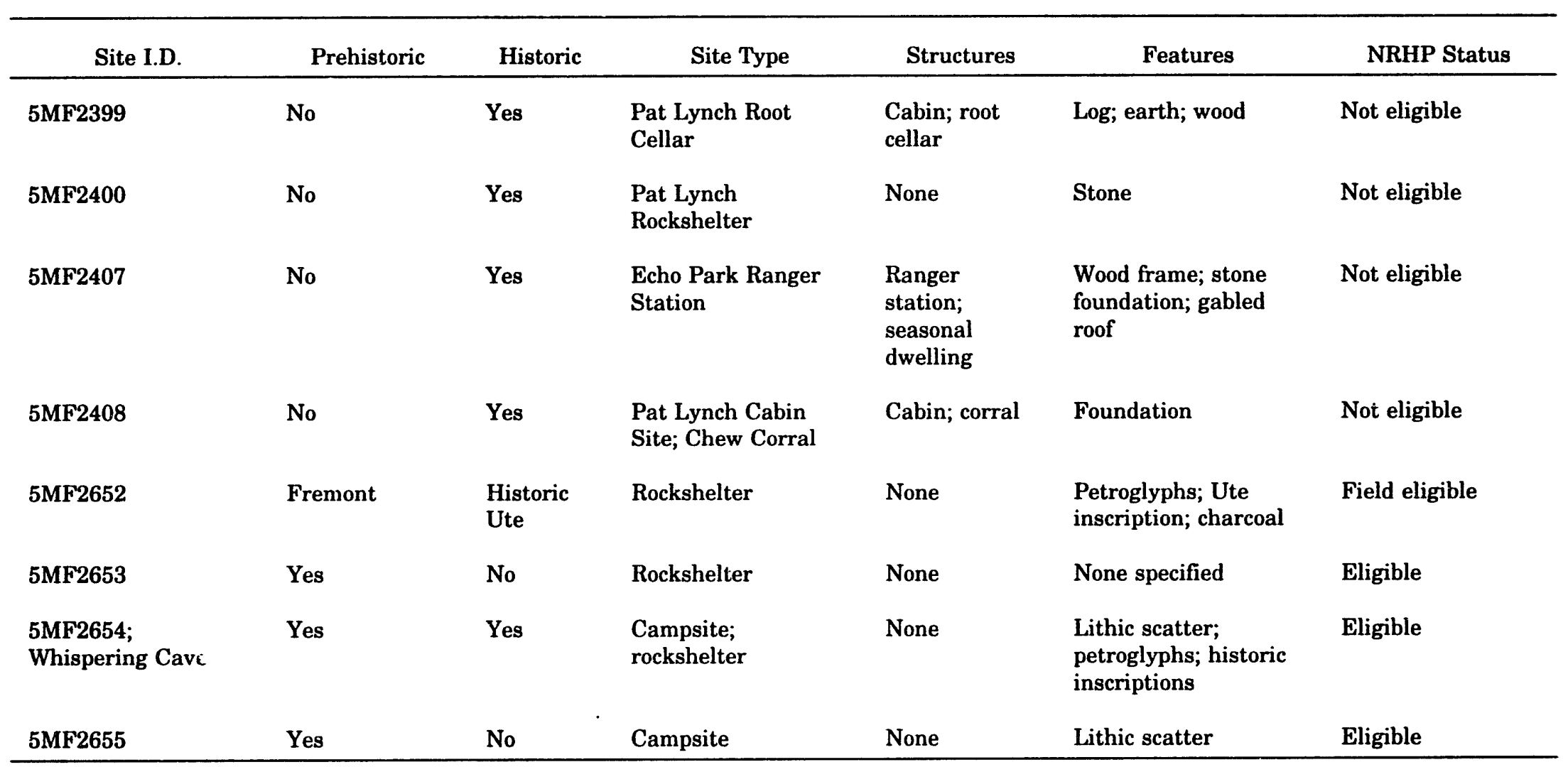


locations. Historic sites in the study area include a variety of structures and features (e.g., ranches, houses, cabins, and trails). Their distribution is less influenced by sampling (i.e., field surveying) because of their greater visibility in the historic record and on the landscape (most contain structures).

The study area corridor, which extends from Flaming Gorge Dam to the mouth of Cub Creek, has been subdivided into two segments or reaches: (1) Flaming Gorge Dam to the Yampa River confluence, and (2) the Yampa River confluence to Cub Creek. The corridor measures $0.5 \mathrm{mi}$ from each side of the river and $0.5 \mathrm{mi}$ from the margins of the reservoirs, and/or up to $60 \mathrm{ft}$ above mean water level; in almost all portions of the study area, the 60-ft level falls within the $0.5-\mathrm{mi}$ zone.

\subsubsection{Reach 1: Flaming Gorge Dam to the Yampa River Confluence}

The upper and central portion of Reach 1 (Flaming Gorge Dam to the Dinosaur National Monument boundary) has been subject to a river corridor survey (200-ft corridor) (Norman and Merrill 1981) and to surveys of portions of Browns Park (Lindsay 1986a, 1986b). However, some of the 59 prehistoric, 27 historic, and 3 combined prehistoric/historic sites (listed in Table 3) have been reported through smaller surveys and incidental discoveries (e.g., Madsen and Sargent 1979; Meyer and Riches 1979). Five of the historic sites are listed on the NRHP, and 23 of the prehistoric, 16 of the historic sites, and 2 combined prehistoric/historic sites are considered eligible or potentially eligible for the NRHP.

At the upper end of this reach (from Flaming Gorge Dam to 2 to $3 \mathrm{mi}$ below the confluence of Red Creek), the river flows through Red Canyon and Devils Hole, where the narrow confines of the valley have apparently limited the number of sites. A total of 16 prehistoric, 4 historic, and 1 prehistoric/historic sites are currently recorded. Only one site (42DA30), which represents the remains of a late prehistoric structure in Red Canyon (300 $\mathrm{ft}$ above river), is located near Flaming Gorge Dam (Day and Dibble 1963:77). Most sites are concentrated farther downstream near the mouths of Goslin, Gorge, and Davenport creeks; these sites primarily represent prehistoric lithic scatters situated on low terrace surfaces on both sides of the river (e.g., 42DA223, 42DA224, 42DA332, 42DA335). Several lithic scatters (e.g., 42DA166, 42DA174) and one rockshelter (42DA226) are found on higher terrace surfaces. Most of these sites have reportedly been subject to some erosion, and several have been vandalized (presumably by campers and rafters) (Norman and Merrill 1981). This concentration of sites also includes historic log cabins (42DA167), a structure foundation (42DA211), a mining camp (42DA227), a wagon road/fence (42DA333), and a corral (42DA332). The historic sites are located on both the low and high terrace surfaces, and have also been exposed to erosion and some vandalism (Norman and Merrill 1981).

The middle portion of this reach extends from $3 \mathrm{mi}$ below the mouth of Red Creek to Gates of Lodore and lies within Browns Park. The valley is relatively broad along this segment of the river, and 41 prehistoric, 19 historic, and 2 combined prehistoric/historic sites are currently recorded. Several prehistoric lithic scatters (some containing former hearths) are distributed on the wide low terraces in the Tolivers Creek area; the majority of these sites 
are not associated with side-valley creeks and ravines (e.g., 42DA69, 42DA202, 42DA339, 42DA377, 42DA487) (Norman and Merrill 1981). The Tolivers Creek area also contains several historic sites and features, including an irrigation ditch (42DA394), stagecoach route (42DA395), bridge (42DA342), and John Jarvie Ranch.

The largest group of prehistoric sites (primarily lithic scatters) along this portion of the reach occurs in the hills on the south side of the river, which are drained by Sears Creek, Rye Grass Draw, and Crouse Creek (Lindsay 1986a, 1986b). Although most of them lie outside the study area corridor, several sites on the lower slopes near Sears Creek (42DA419, 42DA420, 42DA436, and 42DA438) and near the mouth of Rye Grass Draw (42DA52, 42DA59, and 42DA402) fall within the corridor boundary. Another group of sites is concentrated on the hills south of Swallow Canyon (42DA409 through 42DA417). Prehistoric lithic scatters are also found on the low terrace surface in the vicinity of the mouth of Sears Creek (42DA6, 42DA228, 42DA339, 42DA241, 42DA488), including the north side of the river (42DA196); these sites are located close to the river and are potentially subject to erosion.

Between Swallow Canyon and Dummy Bottom (situated approximately $3 \mathrm{mi}$ upstream of Gates of Lodore), a number of historic and prehistoric sites are distributed along the broad floodplain or low terraces. Especially notable among the historic sites is Fort Davy Crockett (5MF605) located in Harry Hoy Bottom (Section 2.3.1). Other historic sites include Mike Flynn Cabin (5MF1231), James Warren Cabin (5MF1232), Larry Curtin Cabin (5MF1235), Two Bar Ranch (5MF1126), and Lodore School (5MF1127). The prehistoric sites include lithic scatters (5MF1228, 5MF1230, 5MF841), a petroglyph (5MF688), and tipi rings (located in Flynn Bottom) (5MF840). At least one prehistoric lithic scatter (5MF2746) and one isolated artifact (5MF1752) are located along the higher slopes above the river bottom areas. According to Norman and Merrill (1981), many of the sites (prehistoric and historic) on the floodplain and low terraces have been exposed to erosion damage.

The Green River floodplain narrows between Dummy Bottom and the Gates of Lodore. Prehistoric sites along this portion of the study area corridor are limited to lithic scatters on slopes and hills above the river bottom (5MF242, 5MF248, and 5MF249).

In the lower portion of Reach 1, the river flows through a narrow canyon from the Gates of Lodore to the Yampa River confluence. No prehistoric archaeological sites are reported from the canyon floor, and it appears likely that few prehistoric remains occur along the narrow (sometimes completely absent) floodplain. One historic site (Wade and Curtis Cabin [5MF2357]) was located in the canyon approximately $1.5 \mathrm{mi}$ downstream of the Gates of Lodore; this site has been moved to Lodore Ranger Station. Two archaeological sites (5MF272 and 5MF273) are located on the high bedrock surface on the west side of the river at the upper end of the Canyon of Lodore; no details are available. The presence of these sites (as well as additional sites located outside the study area corridor) suggests that others are probably distributed along the high surfaces above the canyon; however, sites in these areas are not likely to be exposed to adverse effects from river erosion or vandalism. Although three sites (5MF62, 5MF2406, 5MF2656) occur on the north side of the Yampa 
River mouth (i.e., upstream of the confluence), these localities are part of a large concentration of sites that falls primarily within Reach 2 (discussed in Section 2.6.2).

\subsubsection{Reach 2: Yampa River Confluence to Cub Creek}

Along most of this reach, the Green River flows through narrow canyons that afforded limited opportunities for prehistoric or historic settlement (e.g., Whirlpool Canyon, and Split Mountain Canyon). However, sites are more common where the Green River floodplain broadens (particularly Echo Park, Island Park, and areas downstream of Split Mountain); most of these areas have been subject to archaeological surveying (Breternitz 1965; Holmer 1979; Truesdale et al. 1989). At least 48 prehistoric, 4 historic, and 3 combined prehistoric/historic sites are currently recorded along this reach; none of these sites is listed in the NRHP, although 19 prehistoric and 2 prehistoric/historic sites are considered eligible or potentially eligible (Table 4 ).

The largest concentration of sites (18 with prehistoric and 5 with historic components) is found near the Yampa River confluence and Echo Park (Breternitz 1965; Truesdale et al. 1989). Prehistoric sites include a lithic scatter located on the high floodplain (5MF2655), five rockshelters (5MF67, 5MF70, 5MF90, 5MF91, 5MF92), and three petroglyph sites (5MF87, 5MF89, 5MF157) located on the slopes of the high terrace. At least one of these sites (5MF91) has been exposed to erosion, and one site (5MF92) has been vandalized (Truesdale et al. 1989). Several historic sites also occur on the high floodplain or a low terrace - including the Echo Park Ranger Station (5MF2407), and the Pat Lynch Root Cellar, Rockshelter, and Cabin (5MF2399, 5MF2400, 5MF2408). The remaining sites in the area are prehistoric localities found on the bedrock slopes and uplands along Pool Creek; they include three rockshelters (5MF156, 5MF2653, 5MF2654), one petroglyph (5MF88), four lithic scatters (5MF169, 5MF170, 5MF171, 5MF2119), an isolated hearth (5MF86), a human burial (5MF66), and nine other sites for which no information is currently available.

Below Echo Park, the Green River flows through Whirlpool Canyon, which contains only two recorded sites. An historic site (HS-367) is located on the north bank of the river approximately $1.5 \mathrm{mi}$ upstream of Jones Creek (Mehls 1985); no additional information is currently available. 


\section{GUNNISON RIVER}

\subsection{ENVIRONMENTAL SETTING}

\subsubsection{Physiography}

The Gunnison River study area (from Blue Mesa Reservoir to Crystal Dam) encompasses three dam sites on the Gunnison River in the Black Canyon of the Gunnison: Blue Mesa Dam, Morrow Point Dam, and Crystal Dam. Part of Black Canyon lies within a transitional zone between two physiographic provinces, the Colorado Plateau and the Southern Rocky Mountains, but most of this canyon lies within the Colorado Plateau region (Hansen 1987:12).

The Colorado Plateau is characterized by horizontal rock formations, high elevations (5,000 to $11,000 \mathrm{ft}$ above MSL), numerous canyons, and eroding and retreating slopes (Fenneman 1931:274-75 in Grady 1984:1). The Southern Rocky Mountains zone to the west is distinguished by its vegetation, such as scrub oak, chokecherry, mountain mahogany, and Rocky Mountain juniper (Hansen 1987:12).

The Gunnison River originates in Almont, Colorado, and converges with the Ohio and Tomichi creeks in Gunnison. The river then enters the Black Canyon of the Gunnison near Blue Mesa Dam. Major tributaries within the study area include the Lake Fork of the Gunnison, as well as Cebolla, Blue, and Cimarron creeks. Additional drainages include several creeks: Willow, Steuben, Stevens, East and West Elk, Soap, Pine, and Dry - as well as several gulches: Haystack, Dillon, Cottonwood, Dry, and Fourmile. The Gunnison River and its tributaries are responsible for the steep and predominantly narrow canyons that are characteristic of the Black Canyon area; the gradient of the Gunnison is especially steep, averaging a 43-ft/mi drop below Blue Mesa Dam (95-ft/mi drop within the Black Canyon of the Gunnison National Monument) (Hansen 1987:10). Although sparse, some floodplains, low terraces, and alluvial fans occur along the major drainages. A large basin, now the Blue Mesa Reservoir, is located just upstream of Black Canyon. Mesas, ridges, and badlands sloping toward the river valley constitute the remaining areas. Along the river, erosion can be severe due to the steep slopes and shallow soils (Hunter and Spears 1975:81; Stiger and Carpenter 1980:5; Hansen 1987:9-11).

\subsubsection{Geology and Soils}

For over two million years, the Gunnison River has been steadily cutting into both sedimentary and metamorphic formations to form the Black Canyon of the Gunnison. Although this erosional process continues today, it has been altered by the controlled flow of the river brought about by construction of the dams. The sedimentary layers include formations of limestone, shale, and sandstones of Paleozoic age. Cambrian and Precambrian metamorphic and igneous rock formations (primarily granite, gneiss, and schists) underlie 
the sedimentary rock. The resulting stratigraphy includes outer rims of the canyon that principally consist of Dakota sandstone and inner rims that consist of Precambrian rocks. Other components of the canyon include mica, quartzite, feldspar, and garnet (Hansen 1971:21-22; Chronic 1980:223-228; Stiger and Carpenter 1980:3-6; Taylor River Ranger District 1982:III-1; Kuntz et al. 1989:53).

Through the Blue Mesa Reservoir area, the narrower portions of tine reservoir are characterized primarily by exposed bedrock and shallow soils. Wider areas of the reservoir contain moderately deep, well-drained calcareous soils formed in locally transported alluvium and deep, well-drained soils formed from rhyolite and rhyolitic tuff. The erosion hazard is moderate to high depending on the vegetative cover (Hunter and Spears 1975:16, 22, maps). Soils along tributary drainages consist of moderately deep to deep, well-drained channery loams formed by locally transported channery and gravelly sediment (e.g., rhyolite, gneiss, and schist). The erosion hazard in these drainages is slight to moderate (Hunter and Spears 1975:22-23, 26, maps). West of the Blue Mesa Reservoir, the area along the river consists mostly of exposed bedrock (on the southern exposure), extremely shallow soils (on the northern exposure), gravel, and boulders. However, on alluvial fans, hills, ridges, and mountains, the soils are moderately deep and consist of well-drained loams (Hunter and Spears 1975:31, maps).

\subsubsection{Climate}

The climate in the study area is typical of a mountainous region, with ccol temperatures and low humidity. The mean annual temperature in Gunnison is $37^{\circ} \mathrm{F}$, with an average of $10^{\circ} \mathrm{F}$ in January and $62^{\circ} \mathrm{F}$ in July (BLM 1980:41).

Approximately half of the total annual precipitation occurs from June through September; the remainder occurs as snow from October through May. At lower elevations, the annual precipitation averages $10 \mathrm{in}$. at Gunnison, $14 \mathrm{in}$. at Lake City, and $11 \mathrm{in}$. at Powderhorn. Precipitation is generally greater at higher elevations, as demonstrated by averages at Crested Butte (27 in.), Sapinero (21 in.), and Silverton (25 in.) (BLM 1980:41).

\subsubsection{Flora and Fauna}

Plant species along the Black Canyon of the Gunnison vary with topography and soils. Typical species include scrub oak (Quercus turbinella), Douglas fir (Pseudotsuga menziesii), and aspen (Populus spp.). In the vicinity of Blue Mesa Reservoir, vegetation includes sagebrush (Artemisia spp.), Arizona fescue (Festuca arizonica), wheatgrass (Agropyron spp.), native bluegrass (Poa sandbergii), and, in some cases, mountain muhly (Muhlenbergia montana). In the lower reaches of the canyon, the predominant vegetation includes juniper (Juniperus osteosperma), pinyon (Pinus edulis), yucca (Yucca spp.), and prickly pear cactus (Opuntia polyacantha). Higher elevations support Engelmann spruce (Picea engelmannii), subalpine fir (Abies lasiocarpa), and quaking aspen (Populus remuloides). A distinct riparian plant community is present along rivers and streams, where 
willows (Salix spp.), alders (Alnus spp.), birches (Betula spp.), and narrowleaf cottonwood (Populus angustifolia) are found. Colorado blue spruce (Picea pungens), tamarisk (Tamarix pentandra), skunkbush (Rhus trilobata), sedges, grasses, and others occur immediately adjacent to watercourses (Hunter and Spears 1975:16; Grand River Institute 1978:10-11; BLM 1980:41-42; Stiger and Carpenter 1980:8; USFS 1982:III-1; Hansen 1987:13).

The Gunnison River area supports a variety of medium and large mammal species. These include elk (Cervus canadensis), mule deer (Odocoileus hemionus), pronghorn antelope (Antilocapra americana), bighorn sheep (Ovis canadensis), mountain goats (Oreamnos americanus), coyote (Canis latrans), mountain lion (Felis concolor), and black bear (Ursus americanus) (USFS 1978:22, 1982:III-1; BLM 1980:62; Taylor River Ranger District 1982:III-13).

In addition, a number of smaller game and nongame species occur in the area, such as cottontail rabbits (Sylvilagus spp.), woodrats (Neotoma spp.), snowshoe hares (Lepus americanus), marmots (Marmota caligata), gophers, and a variety of mice and other rodents (Grand River Institute 1978:11; USFS 1978:22, 1982:III-1; Taylor River Ranger District 1982:III-13; Weber 1991:4). A number of prairie dog towns also exist along the Blue Mesa Reservoir.

Approximately 165 different bird species have been reported from the Curecanti area, including 63 permanent residents, 71 summer residents, and 31 winter residents, migrants, or casuals (Woodbury 1962:9, in Stiger and Carpenter 1980:8-9). Many of these species may be found in the study area. White-tailed ptarmigan (Lagopus leucurus), blue grouse (Dendragapus obscurus), green-winged teal (Anas crecca), and mallard (Anas platyrhynchos) are the only game birds in the area, and Gambel's quail (Lophortyx gambelii) is currently found on national forest land (USFS 1982:III-1).

As a permanent source of water, the Gunnison River supports a number of trout species; among present-day populations are cutthroat (Oncorhyncus clarki), rainbow (O. mykiss), brook (Salvelinus fontinalis), mackinaw (Cristivomer namaycush namaycush), and brown (Salmo trutta) trout. Other game species in the river include kokanee salmon (O. nerka), northern pike (Esox lucius), and white sucker (Catostomus commersoni) (USFS 1982; Weber 1991:4).

\subsection{REGIONAL PREHISTORY}

The major prehistoric cultural periods defined for the general area of the Gunnison River include Paleo-Indian, Archaic (the groups of which are variously termed the Desert Culture, Desert Archaic, or Uncompahgre Complex), and the Formative (Late Prehistoric). Only the Formative cultures (Fremont/Anasazi) are known to have distinctively significant regional characteristics, primarily because of their horticultural economy (Grand River Institute 1978:13); however, actually defining a Formative Period within the Gunnison River Valley is problematic (Section 3.2.3). 


\subsubsection{Paleo-Indian Period (10,000 to 5,500 B.C.)}

The Paleo-Indian Period in the region of the Gunnison River is similar in most respects to the characteristics described in Section 2.2.1 for this period for the Green River area in northwestern Colorado and northeastern Utah. Data indicating Paleo-Indian components of big-game hunting in west-central Colorado include surface finds of projectile points diagnostic of each of the three Paleo-Indian traditions: Clovis (Llano), Folsom, and Plano. Some of the projectile points are isolated finds, but most have been discovered in the midst of Archaic assemblages, possibly indicating "that later groups may have collected and utilized Paleo-Indian artifacts, thereby introducing them into later assemblages," an idea supported by ethnographic accounts of the scavenging of prehistoric artifacts by later groups (Reed 1984:14).

Reed (1984:15) reports that a concentration of Paleo-Indian sites occurs along the Gunnison River east of Blue Mesa Dam, which may indicate that the river was a travel corridor during prehistoric times. Paleo-Indian sites also occur in the areas discussed in this report (Section 3.6).

\subsubsection{Archaic Period (5,500 B.C. to A.D. 500)}

As elsewhere in North America, the transition from big-game hunting to intensified plant use and the hunting of smaller game is characteristic of the Archaic Period. These changes most likely were the result of changing environmental conditions and a population increase that produced changes in available resources. The Archaic Period is typically divided into three phases: Early (5,500 to 3,000 B.C.), Middle (3,000 to 1,000 B.C.), and Late (1,000 B.C. to A.D. 500). The dates of each phase vary according to region (the dates given are for the Colorado Plateau). However, in the Gunnison River Valley it is possible that the Archaic Period lasted until historic times, ca. A.D. 1200 (Section 3.2.3) (Cassels 1983:73-75; Cordell 1984:154; Guthrie et al. 1984:22-23; Reed 1984:17-23).

Although relatively little work has been done on the Archaic Period in this region, Archaic sites predominate in the study area (Section 3.6). Some researchers (e.g., Guthrie et al. 1984 and Reed 1984) suggest the possibility of influence from other cultural regions during this time.

\subsubsection{Late Prehistoric Period (A.D. 500 to 1300)}

The Late Prehistoric Period, or Formative Stage, is problematic in the prehistory of west-central Colorado. Elsewhere, the period is defined by a sedentary lifestyle and the presence of an agricultural subsistence. Nearby Formative cultures include the Fremont, Anasazi, Hohokam, and Mogollon. Comparisons have been made between the Formative Stage sites in the area and the Fremont and Anasazi sites to the west and southwest, respectively. Stylistically, however, the architecture and artifacts found in the west-central sites have not been conclusively characteristic of either culture (Reed 1984:30-42). Other 
possibilities for cultural affiliation include an Athapaskan origin (Huscher and Huscher 1943) and a distinct and as yet unnamed culture group (Reed 1984:41). Reed (1984:39), citing a personal communication with Douglas Scott, presents an explanation in which the Formative Stage culture is an "in situ development from an Archaic technocomplex." Such explanations assume that a Formative Stage actually exists in the area; however, the Archaic Period may have continued through to the Ute tradition in protohistoric and historic times.

An alternative explanation is presented by Guthrie et al. (1984:43-44), who suggest that other Formative groups may have visited or traded with indigenous groups in the area, but upon entering the mountain environment, "Formative peoples only hunted and gathered in an Archaic adaptive strategy." It is also reasonable to suggest that Formative people from other areas, such as the Anasazi and Fremont, may have utilized the region simply for its diversity in faunal and floral resources on a limited, rather than permanent, basis (Guthrie et al. 1984:43).

\subsubsection{Protohistoric Period (A.D. 1300 to 1800)}

The characteristics of the Protohistoric Period in the Gunnison River study area are similar to those described in Section 2.2.4 for the Green River study area.

\subsection{REGIONAL HISTORY}

\subsubsection{Spanish Settlement and Exploration}

European, specifically Spanish, exploration into the study region in the mid16th century marked the beginning of the historic period. Spanish exploration into the American southwest, although not specifically through the present-day boundaries of Colorado, began with the Coronado expedition of 1540 to 1542. Francisco Vasquez Coronado and his company of men traversed the American southwest from the present-day boundaries of New Mexico, northeast through extreme northwestern Oklahoma, to the "great bend" of the Arkansas River in central Kansas (Fritz 1941:60-61; Loosle 1991).

The failure of the Coronado expedition to locate any gold or silver curtailed further Spanish exploration into the region for the next 50 years (Fritz 1941:61). The next expedition to enter the region was led by Juan de Onate in 1598. Onate succeeded in establishing a colonial presence in the region, founding temporary capitals at San Juan (Beck 1962:54) and later San Gabriel. A permanent capital was established for the region at Santa Fe in 1609 (Fritz 1941:61).

During the decades that followed the founding of Santa Fe, Spanish control of the region could probably best be described as a "holding measure" (Beck 1962:61). Although growth of the colony was limited, Franciscan friars were actively converting the local Pueblo Indians to Christianity. The Spanish were briefly driven from the region in 1680 by the 
Pueblo Revolt. The reconquest of the Pueblos and northern New Mexico began in 1692, and the Spanish reoccupied Santa Fe by 1693 (Beck 1962:87-88).

The first documented exploration into the vicinity of the study area itself occurred in 1765. In that year, Juan Maria de Rivera led a prospecting party up from Santa Fe into the area. Traveling north from Santa Fe, Rivera led the party from the San Juan Mountains into the Gunnison River valley. Along the course of the Gunnison River, the party conducted some prospecting work and collected ore samples (Fritz 1941:62). The expedition traveled along the Gunnison as far north as the mouth of the Uncompahgre River.

The next Spanish explorations into the area were precipitated by English and Russian incursions into the Pacific Northwest, which convinced the Spanish of the need for better communication between the New Mexican colony and the California missions. In an attempt to meet those ends, Friar Silvestre Velez de Escalante and another Franciscan, Friar Franco A. Domiguez, led a small party of men from Sante Fe in 1776. Traveling northeast, they crossed the Uncompahgre Valley and reached the Gunnison River below present-day Montrose, Colorado. Continuing northeast from the Montrose area, they crossed the Gunnison River and ascended the North Fork (Hafen 1948:35). Along the North Fork of the Gunnison, Escalante and Dominguez encountered Ute Indians. The party secured two guides from the Utes and traveled northwest across Grand Mesa to the Colorado River (Hafen 1948:35). After crossing the Colorado River, they struck off in a northwesterly direction towards present-day Rangely, Colorado. Continuing west, the group crossed the Green River above the location of present-day Jensen, Utah (Auerbach 1943:41-42 as cited in Lennon et al. 1980:109). The expedition reached as far west as the Great Salt Lake region, but winter weather caused them to abandon the trek and return east to Santa Fe (Baker and Hafen 1927:277).

Other Spanish travel recorded in the Gunnison River Valley region occurred in 1805 and 1813. Manual Mestas entered the region in 1805 to recover horses and mules stolen by the Utes. In 1813, Maucio Arze and Lago Garcia visited the region to trade with the Indians. The pair hoped to trade European goods for furs, but all they could obtain for their efforts were Indian slaves (Lennon et al. 1980:111).

\subsubsection{Euro-American Trappers and Fur Traders}

In 1815, a large Euro-American fur trading party organized by A.P. Chouteau and Julius De Munn of St. Louis first entered southern Colorado and began trapping in the region (Baker and Hafen 1927:303; Chittenden 1954:497-498). The traders realized they were trapping on Spanish-controlled lands and travelled to Santa Fe to secure permission. Julius De Munn traveled to Santa Fe several times but was denied permission each time. In 1817, while attempting to return to St. Louis with furs they had secured, the party was captured by Spanish troops and brought back to Sante Fe. Their furs were confiscated, and the party was jailed for 48 days and sentenced to leave the region upon release (Chittenden 1954:479). 
The harsh treatment the Spanish had shown the Chouteau and De Munn party as well as other traders working in the area served to discourage further trapping in the region for the next several years. With the advent of Mexican independence from Spain in 1821, more favorable conditions for trapping and trading developed for the Euro-Americans. In 1822, the Mexican government gave the Glen and Fowler trading party permission to trap in the Mexican provinces. By the winter of 1823 , the Fowler party was trapping along the headwaters of the Rio Grande River (Baker and Hafen 1927:305).

The loosening of Mexican government restrictions opened up the region to independent trappers as well. Important to the history of the study area and the Gunnison River drainage was a trader named Antoine Robidoux. Sometime in the 1830s, Robidoux established a trading post along the Gunnison River below the mouth of the Uncompahgre River, near the present-day town of Delta (Hill 1930:128; Hafen 1948:79; Lennon et al. 1980:115). The history of Fort Robidoux (or Fort Uncompahgre as it was also called) is not well known. Although never a particularly important fur-trading post, it was one of the few posts located on the western slope of the Rockies and seems to have been in existence from sometime in the 1830 s to at least 1842 . The remains of the post were still evident in 1853 when the Gunnison expedition noted its existence during their trip down the valley (Hill 1930:128; Hafen 1948:79).

\subsubsection{Territorial Period and Early Statehood}

With the end of the Mexican War and the signing of the treaty of Guadalupe Hidalgo in February 1848, Mexico gave up claims to a vast region of territory north and west of the Rio Grande and Gila rivers, including the area that would become Colorado (Hafen et al. 1970:226). In September 1850, the western third of what was to become the state of Colorado was organized into the Territory of Utah (Hafen et al. 1970:257).

Increased growth in the West by the early $1850 \mathrm{~s}$, fostered by the arrival of California gold seekers and immigrants to Oregon country, led Congress to recognize the need for a transcontinental railroad. In 1853, Congress designated funds to survey several proposed railroad routes (Lennon et al. 1980:117). Captain J.W. Gunnison was given the task to survey the central route, which included areas along the Grand River (an earlier name for the Gunnison River). In June 1853, Gunnison and his party of railroad surveyors set out from St. Louis. The central route through the study area consisted of heading over Cochetopa Pass to the Gunnison River and following the river valley westward. The party followed the river as far as Sapinero, where it became impassable, and then cut across the Lake Fork and headed south of Black Canyon toward Cedar Creek and the Uncompahgre River. The Gunnison party proceeded west out of the valley and, near the location of Grand Junction, picked up the Old Spanish trail into Utah. While camped by the Sevier River, Gunnison and several members of the party were killed by Indians. The expedition was completed by the remaining members of his party (Hunter 1925:3; Hafen 1948:95-96).

The Pike's Peak gold rush of 1859 brought a great number of miners and immigrants into the region (Hafen et al. 1970:304). The miners showed little respect for the existing 
territorial governments. At this time, the present-day state of Colorado was located within the boundaries of four territories: New Mexico, Utah, Kansas, and Nebraska. To remedy the situation, Congress established the Colorado Territory in 1861 and President Lincoln appointed Major William Gilpin as governor (Hafen et al. 1970:306).

In 1871, a permanent cattle camp was established near Gunnison to supply beef to the Ute Indians of the Los Pinos Agency (Hagie 1931:121). The Ute Reservation, as defined by the Treaty of 1868 , consisted of a large portion of the western third of the Colorado Territory (Fritz 1941:285; Grand River Institute 1980:27). The Utes attempted to resist encroachments into their reservation, but the discovery of gold and silver in the San Juan Mountains caused miners to flood into the region. The Treaty of 1873 ceded the San Juan Mountains to the United States in return for a monetary concession (Fritz 1941:286). Further encroachment onto Ute lands and problems with a Ute agent (Nathan Meeker) resulted in the eruption of two conflicts now known as the "Meeker Massacre" and the "Milk Creek Ambush." These events precipitated the Treaty of 1880, in which the Utes ceded most of their lands in Colorado to the government and were removed to the Uintah Reservation in Utah. In June 1882, Congress opened up the former Ute Reservation to setilement, but most of the prime land had been occupied since September 1881 when the last Utes were removed (Fritz 1941:289-290; Grand River Institute 1980:28-29).

The Colorado territory achieved statehood in 1876 (Hafen et al. 1970:307). Extensive settlement had already occurred in the study area at the time of statehood. The Gunnison area had been settled by large cattle ranchers before 1874 , and the town of Gunnison was organized in 1874. However, all these settlements were abandoned when gold fever hit the region after the discovery of gold in the San Juan Mountains (Hagie 1931:122-124; Lennon et al. 1980:131-135).

Settlement of the region began in earnest in 1879 when coal was discovered on Upper (North) Tomichi Creek, on Quartz Creek, and at Taylor Park, and with the formation of a new Gunnison Town Company. It was not unknown for a new town, comprising 100 tents and cabins, to appear in one week (Dorset 1970:281). In 1881-1882, the Denver and Rio Grande and the Denver and Southpark railroads reached the town, and a spur line was extended north from Gunnison to the coal fields in Crested Butte (Lennon et al. 1980:148). Gunnison also served the needs of the local cattle industry, which allowed the town to survive the panic of 1893, when many local mining towns were abandoned (Lennon et al. 1980:160).

Grand Junction, Delta, and Montrose (the other three major towns near the study area) were established during 1881-1882 on former Ute Reservation lands. Unlike Gunnison, these towns were all founded as agricultural communities (Baker and Hafen 1927:460). The growing season and climate of this region was recognized as being optimal for fruit agriculture, particularly apples and peaches (Fritz 1941:279; Grand River Institute 1980:30). The success of fruit agriculture in the region was contingent on irrigation. The first irrigation canals were constructed with private funding or were excavated by local farmers; by the early 20 th century, the government had begun to support large-scale irrigation projects (Lennon et al. 1980:158; Grand River Institute 1980:31). The Denver and Rio Grande 
Railroad was linked up across the study area in 1882 and reached Salt Lake City in the following year. The extension of the railroad provided access to markets to the east and west for Gunnison Valley produce, and by the 1890 s the region was the primary fruit-producing area of the state (Grand River Institute 1980:32). The Uncompahgre irrigation project (constructed during 1904-1909) was the first U.S. Bureau of Reclamation project on the western slope in Colorado. The project consisted of a tunnel through the granite rock of the Uncompahgre Mountains that was designed to divert water from the Gunnison River to the Uncompahgre River for expanded irrigation (Fritz 1941:338-341).

\subsection{REGIONAL ETHNOGRAPHY: UTE}

The Ute inhabited both the southern Green River and the Gunnison River study areas. Section 2.4 contains a detailed discussion of Ute lifeways applicable to both areas, and Section 3.3.3 also contains information regarding Ute history specific to the Gunnison region.

\subsection{PREVIOUS RESEARCH}

Because the Gunnison River drainage appeared to lack the obvious and impressive prehistoric remains of the neighboring Anasazi and Fremont areas, it did not attract the attention of early archaeologists. Some early work was conducted in the 1930s and 1940s by C.T. Hurst and by B.H. and H.A. Hurscher (Guthrie et al. 1984; Reed 1984), but it was dam construction on the Gunnison (which resulted in the creation of the Cureranti National Recreation Area) and the cultural resources inventory of the Black Canyon of the ('unnison National Monument that provided the impetus for conducting systematic cultural ?esource surveys in the area. In the post-dam era, several small-scale, project-specific sur, eys have been conducted. Archaeological inventories of government lands receiving scureational use were conducted in the 1970 s and 1980s.

All of the known surveys within the Gunnison River study area are presented in Table 5. The study area encompasses the land along the Gunnison from the Blue Mesa Reservoir to the Crystal Dam in the Black Canyon of the Gunnison. The length of this corridor is restricted to $44 \mathrm{mi}$ due to the presence of the Crystal reregulation dam. The study area has been subdivided into three reaches for further discussion: (1) Blue Mesa Reservoir, (2) Blue Mesa Dam to Morrow Point Dam, and (3) Morrow Point Dam to the Crystal Dam (Figure 15). Nearly $80 \%$ of the study area has been subject to intensive archaeological surveys (Figures 16-20).

In summary, the Gunnison project area appears to have been well surveyed. The area closest to the original Gunnison riverbed is the least well known. Now largely under water, this area was the most subject to disturbance by modern construction, cultivation, and the action of the river itself. 
TABLE 5 Previous Archaeological Surveys in the Gunnison River Study Area

\begin{tabular}{|c|c|c|c|c|c|c|c|c|}
\hline Project Name & Year & $\begin{array}{c}\text { Area } \\
\text { Surveyed }\end{array}$ & $\begin{array}{l}\text { Percent } \\
\text { Sampled }\end{array}$ & $\begin{array}{c}\text { Survey } \\
\text { Code }^{\mathrm{a}}\end{array}$ & $\begin{array}{l}\text { Sampling } \\
\text { Procedures }\end{array}$ & $\begin{array}{c}\text { Number } \\
\text { of Sites } \\
\text { Recorded }\end{array}$ & $\begin{array}{l}\text { Number } \\
\text { in ANL } \\
\text { Database }^{c}\end{array}$ & Reference \\
\hline \multicolumn{9}{|l|}{ Reach 1: Blue Mesa Reservoir } \\
\hline $\begin{array}{l}\text { Archaeological Survey of the } \\
\text { Blue Mesa Reservoir, } \\
\text { Colorado }\end{array}$ & 1962 & Not specified & $\mathbf{N S}^{\mathbf{d}}$ & 1 & $\begin{array}{l}\text { Four-wheel-drive vehicle and } \\
\text { pedestrian survey; not } \\
\text { plotted. }\end{array}$ & $10^{e}$ & $2 \mathrm{GN}-34$ & Lister (1962) \\
\hline $\begin{array}{l}\text { Archaeological Inventory } \\
\text { and Evaluation of Curecanti } \\
\text { Recreation Area }\end{array}$ & 1976 & $\begin{array}{l}\text { Entire Curecanti } \\
\text { Recreation Area }\end{array}$ & $100 \%$ & 3 & $\begin{array}{l}\text { Transects spaced } 30 \text { to } 160 \mathrm{ft} \\
\text { apart. No subsurface } \\
\text { testing. }\end{array}$ & $\begin{array}{c}100(134) / \\
2 R^{f, g}\end{array}$ & $\begin{array}{c}3 G N-8 \\
1 G N-3 B\end{array}$ & $\begin{array}{l}\text { Stiger (1977) } \\
\text { Stiger (1980) }\end{array}$ \\
\hline $\begin{array}{l}\text { Recent Archaeological } \\
\text { Surveys in Curecanti } \\
\text { National Recreation Area }\end{array}$ & 1990 & 1 acre & $100 \%$ & 3 & Not specified. & $1 / 1 R^{h}$ & $1 \mathrm{GN}-5$ & NPS (1990) \\
\hline $\begin{array}{l}\text { Cultural Resources Survey } \\
\text { of Part of the Gunnison } \\
\text { State Wildlife Area }\end{array}$ & 1991 & 48 acres & $100 \%$ & 3 & $\begin{array}{l}\text { Parallel transects spaced } 10 \\
\text { to } 20 \mathrm{ft} \text { apart }\end{array}$ & $2 / 1 \mathrm{R}$ & $2 \mathrm{GN}-10$ & Weber (1991) \\
\hline \multicolumn{9}{|c|}{ Reach 2: Blue Mesa Dam to Morrow Point Dam } \\
\hline $\begin{array}{l}\text { Archaeological Survey of the } \\
\text { Morrow Point Dam Area, } \\
\text { Montrose and Gunnison } \\
\text { Counties }\end{array}$ & 1964 & Not specified & NS & 3 & $\begin{array}{l}\text { Vehicular and pedestrian } \\
\text { survey. Intensive coverage } \\
\text { of alluvial fans; not plotted. }\end{array}$ & 0 & $3 G N-5$ & Buckles (1964) \\
\hline $\begin{array}{l}\text { Archaeological Inventory } \\
\text { and Evaluation of Curecanti } \\
\text { Recreation Area }\end{array}$ & 1976 & $\begin{array}{l}\text { Entire Curecanti } \\
\text { Recreation Area }\end{array}$ & $100 \%$ & 3 & $\begin{array}{l}\text { Transects spaced } 30 \text { to } 160 \mathrm{ft} \\
\text { apart. No subsurface } \\
\text { testing. }\end{array}$ & $3(134)$ & $\begin{array}{c}3 G N-8 \\
1 G N-3 B\end{array}$ & $\begin{array}{l}\text { Stiger (1977) } \\
\text { Stiger (1980) }\end{array}$ \\
\hline
\end{tabular}


TABLE 5 (Cont.)

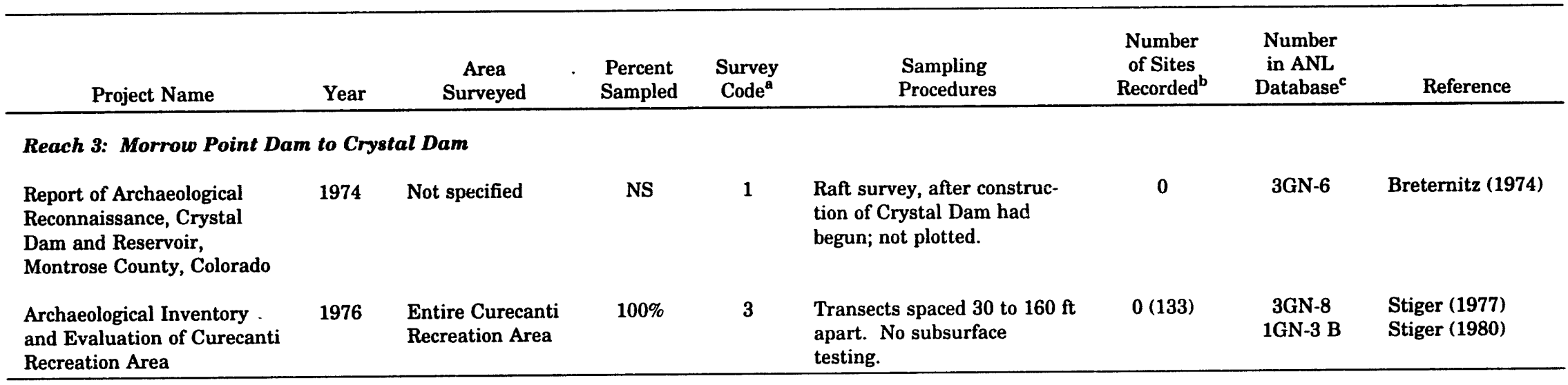

a Survey code: 0 , type of survey not specified in report or data incomplete; 1 , unsystematic survey - includes random walkovers, compilations, etc.; 2 , sampling methods used; 3 , intensive survey, usually covering $100 \%$ of area.

b Number in parentheses is total number of sites recorded during survey; first number denotes number of sites in the specific area.

c Survey number in ANL database; corresponds to numbered survey areas on Figures 3 through 8.

d NS indicates not specified.

e Eight of these sites have been inundated by Blue Mesa Reservoir.

f $\mathbf{R}$ indicates number of sites relocated (i.e., previously recorded in another survey).

g The two sites were initially recorded in the Lister (1962) survey (2GN-34).

h 5GN196, largely destroyed. 


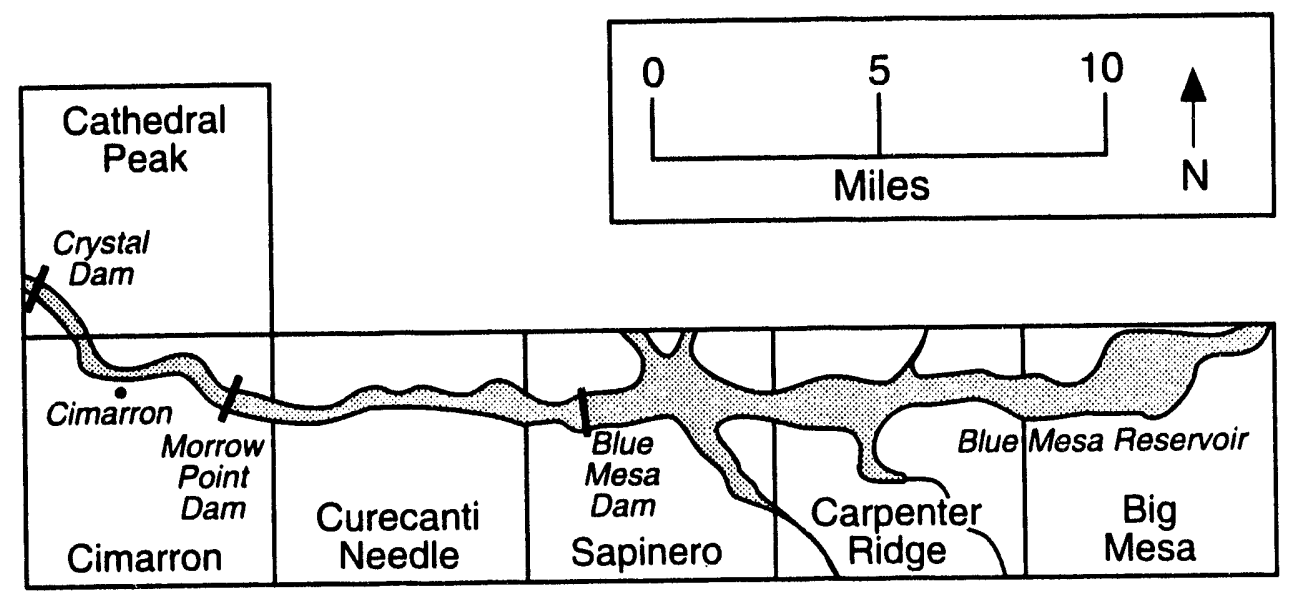

FIGURE 15 Gunnison River Study Area

\subsubsection{Reach 1: Blue Mesa Reservoir}

Reach 1 consists of the land area along the Blue Mesa Reservoir. The earliest survey within this reach, a random and somewhat intuitive survey combining pedestrian and vehicular methods, was conducted prior to dam construction. The survey was apparently performed by using informants who remembered the Ute usage of the area and examined "every portion that offered even the remotest possibility of containing archaeological remains" (Lister 1962:2). Although the survey does not seem to have been systematic by today's standards and may have excluded the land closest to the Gunnison River because it was under cultivation, the survey located 10 archaeological sites. Subsequent to this survey, a series of intensive, comprehensive surveys were conducted in the area over the next several decades (Table 5). The surveys were surficial walkovers in transects spaced anywhere from 15 to $150 \mathrm{ft}$ apart (Stiger 1977, 1980; NPS 1990; Weber 1991).

\subsubsection{Reach 2: Blue Mesa Dam to Morrow Point Dam}

Reach 2 consists of the land from Blue Mesa Dam to Morrow Point Dam, the majority of which borders Morrow Point Reservoir. The earliest survey within this reach, conducted prior to dam construction, examined the narrow canyon bottoms, which have little or no floodplain. A combination of pedestrian and vehicular surveys covered a 12-mi corridor; any alluvial fans along the river were intensively surveyed. No sites were found during this survey (Buckles 1964). Subsequent to Buckles' survey of the river corridor, the study area was subject to an intensive survey as part of the inventory of Curecanti National Recreation Area (Stiger 1977, 1980).

\subsubsection{Reach 3: Morrow Point Dam to Crystal Dam}

Reach 3 consists of the area from Morrow Point Dam to Crystal Dam. The earliest survey within this reach was conducted after dam construction had already begun. 
Breternitz (1974), working in steep, narrow canyon bottoms with little or no floodplain, found no archaeological sites. The study area was then subjected to an intensive survey covering the entire Curecanti National Recreation Area (Stiger 1977, 1980). No sites have been located within this reach.

\subsection{RECORDED SITES}

The Gunnison River study area consists of a corridor along the main channel of the Gunnison River from the point of entry of the river into Blue Mesa Reservoir and on to Crystal Dam. This corridor includes a distance of $0.5 \mathrm{mi}$ on both sides of the river and reservoir, and extends to a minimum height of $60 \mathrm{ft}$ above the area subject to inundation as drawn on the USGS topographic map (full pool of reservoir = approximately $7,520 \mathrm{ft}$ above MSL). The corridor is divided into three reaches: (1) Blue Mesa Reservoir, (2) Blue Mesa Dam to Morrow Point Dam, and (3) Morrow Point Dam to Crystal Dam.

Six surveys, covering about $80 \%$ of the study area (Figures 16 through 20 ), have been conducted within the corridor (Section 3.5). To date, 144 sites have been recorded in the study area as a result of surveys, incidental discoveries, and known historic sites. The majority of known resources in the area were recorded in an archaeological inventory of the Curecanti Recreation Area taken in 1976, in which Stiger (1977, 1980) recorded over

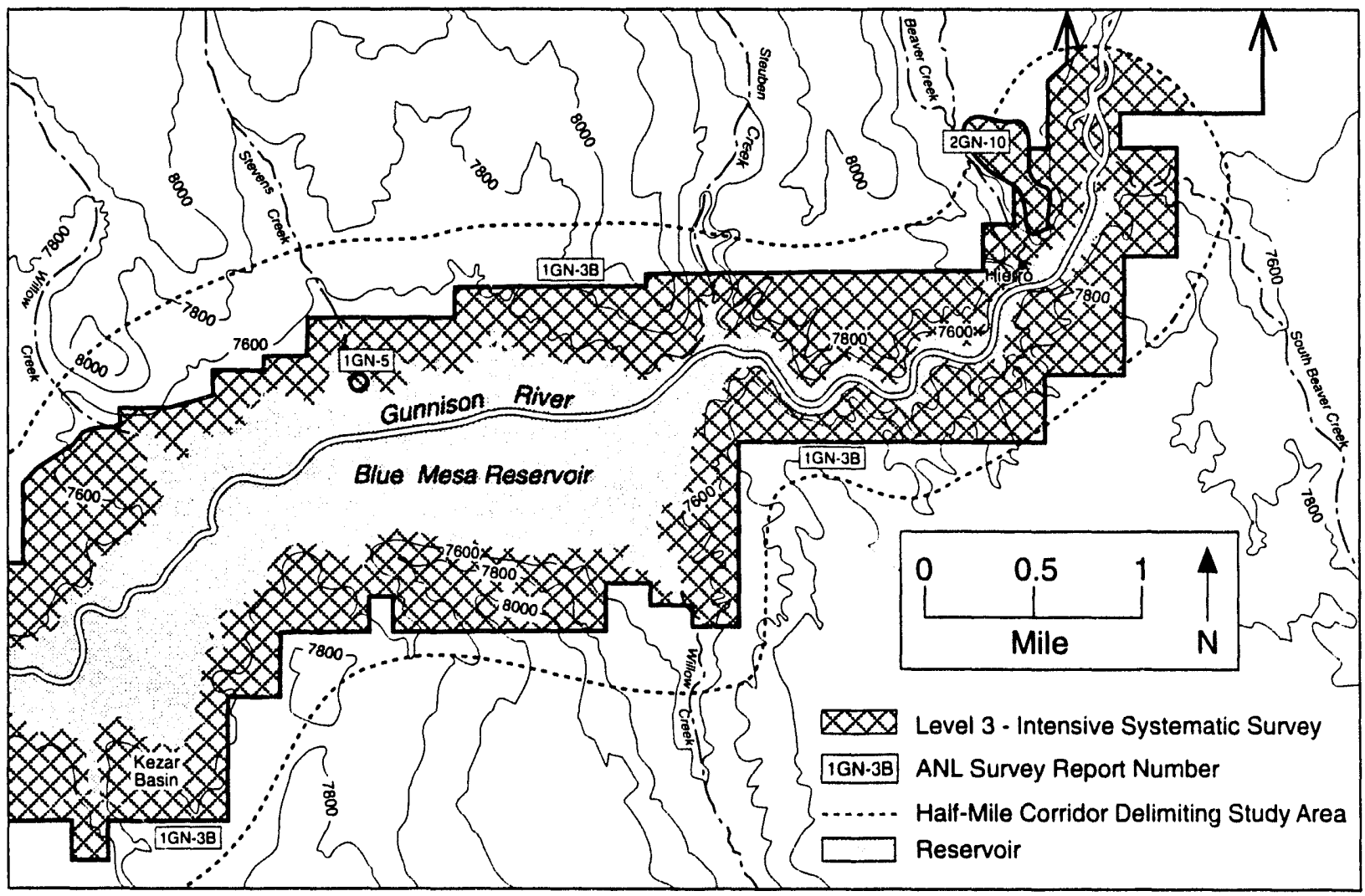

FIGURE 16 Previous Archaeological Surveys: Big Mesa 


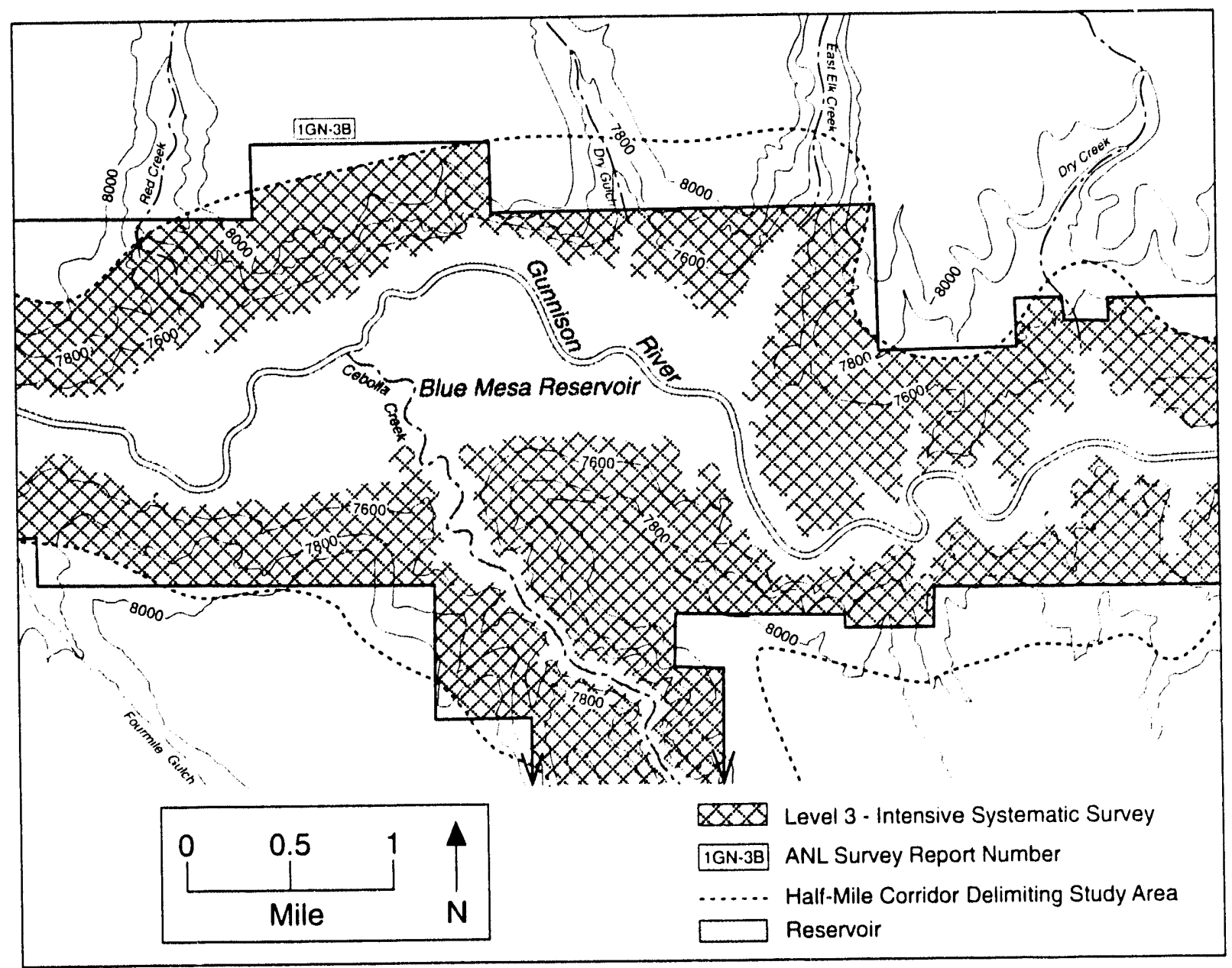

\section{FIGURE 17 Previous Archaeological Surveys: Carpenter Ridge}

130 sites; 100 of those sites are within the 0.5 -mi corridor around the reservoir. Sixty-seven of the recorded sites are in the Curecanti Archaeological District, a National Register (NR) District in the Curecanti Recreation Area nominated in 1982 (i.e., the 67 sites are listed as a collective unit on the NRHP). Eligibility determinations for the NRHP have yet to be made on the remainder of the sites or on individual sites within the NR District. Summaries of known site disturbances pertaining to individual sites are given in Tables A.3 and A.4 of the Appendix.

To summarize the cultural resources in the study area, the area of Blue Mesa Reservoir was a high-use base camp area for aboriginal hunting and its associated activities (tool production and food processing). Many of the sites are strategically located near the mouths of tributaries and lithic sources, and/or in sheltered areas. The area is well-suited for these temporary campsites, with abundant faunal and floral resources, timber, and lithic sources. The other areas along the river were not heavily used due to the steep canyon walls of the Black Canyon of the Gunnison. Only in areas where there are breaks in the cliff face, 


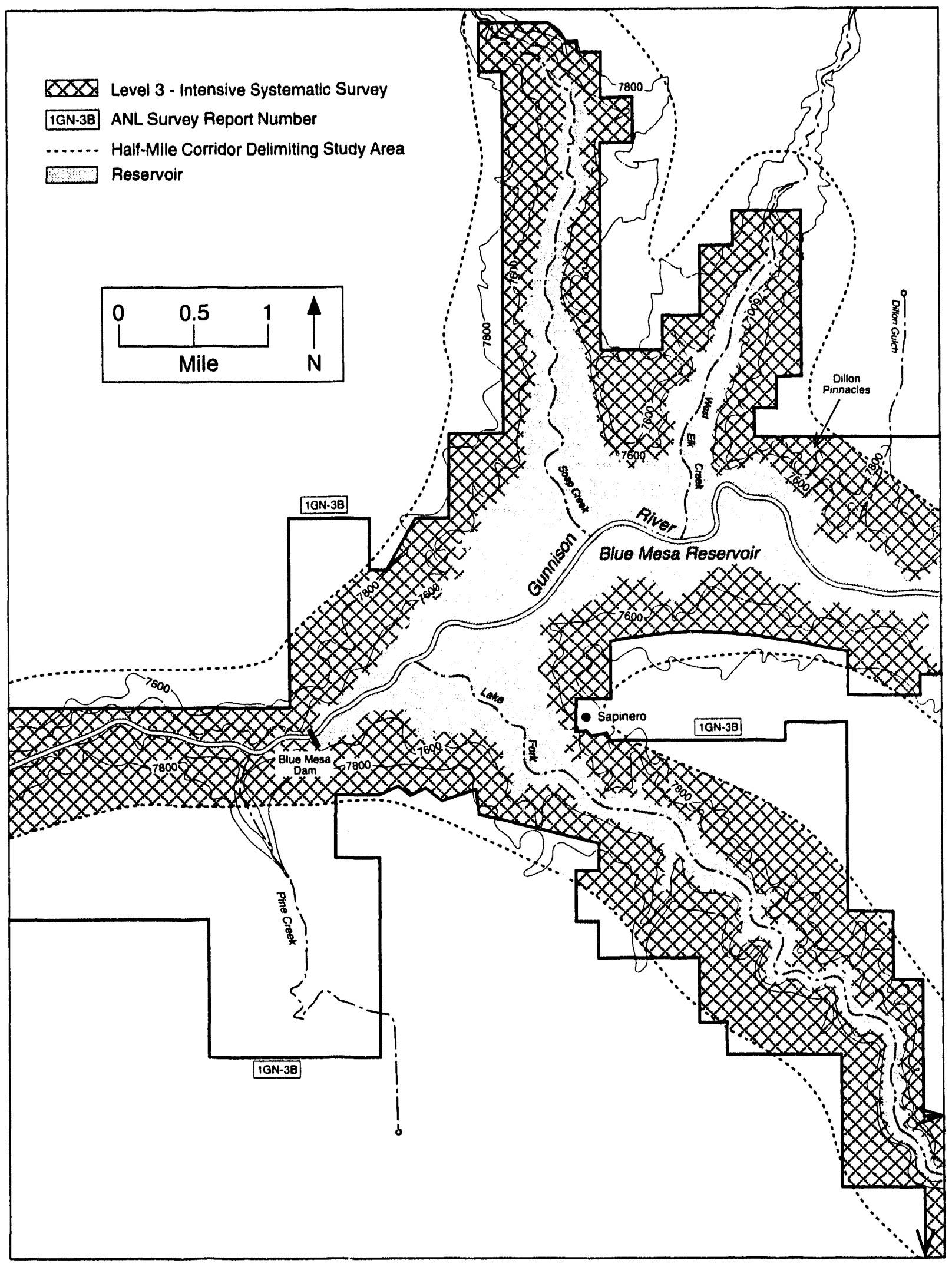

FIGURE 18 Previous Archaeological Surveys: Sapinero 


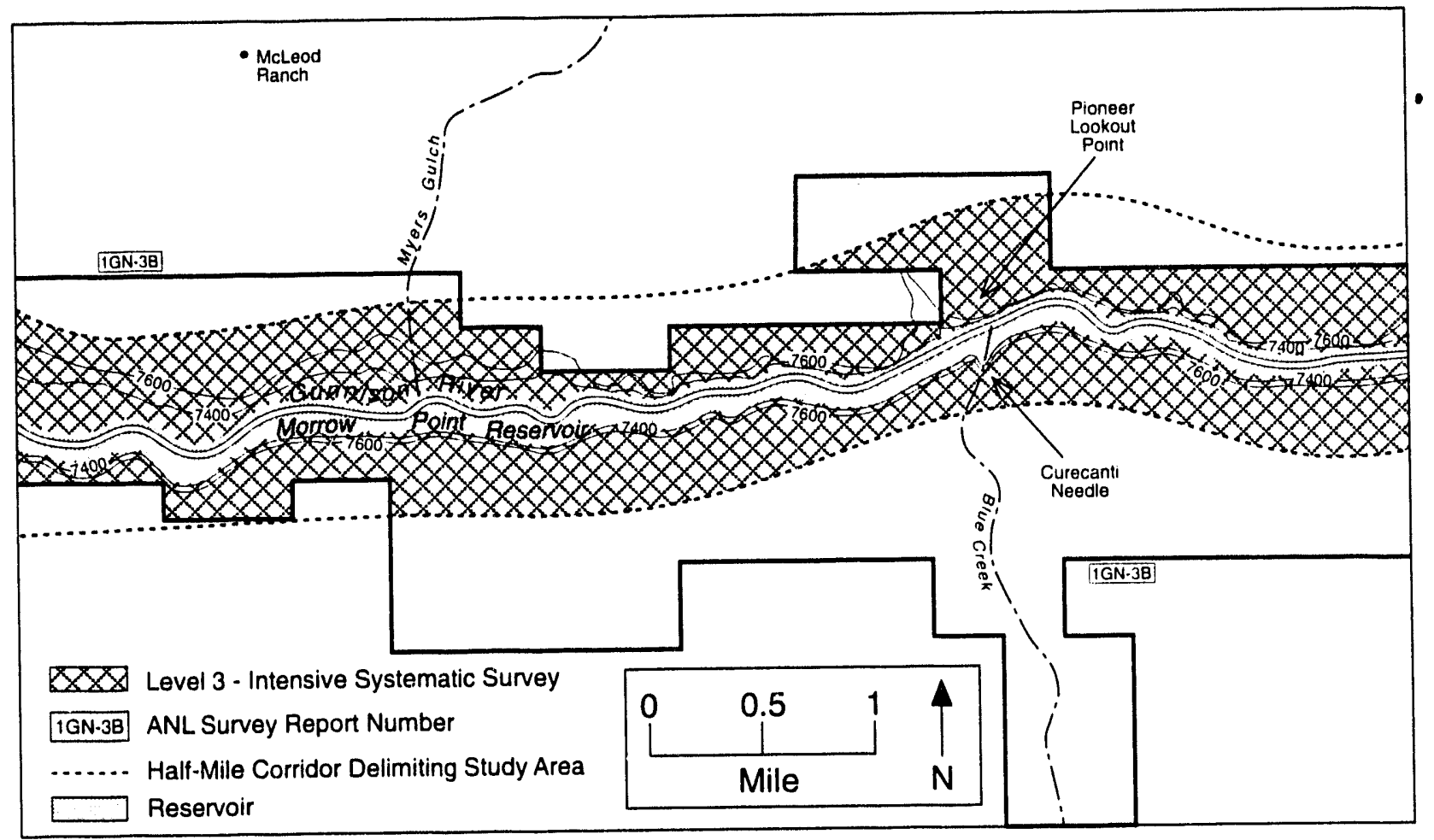

\section{FIGURE 19 Previous Archaeological Surveys: Curecanti Needle}

such as around small tributary drainages, would aboriginal occupation be possible. Extensive historic use of the few alluvial fans along the Morrow Point reach is documented (Buckles 1964). The consistent lack of archaeological evidence appears to support the conclusion by Breternitz (1974) that the Utes usually avoided the deep canyons; however, it is possible that the high waters of the Gunnison, flooding, and historic usage could have removed any evidence of prehistoric occupation of the few existing alluvial fans (Buckles 1964; Breternitz 1974).

\subsubsection{Reach 1: Blue Mesa Reservoir}

One hundred and thirty-three of the 144 sites occur within Reach 1 (i.e., in or around the Blue Mesa Reservoir); 9 sites are completely submerged. These sites are listed in Table 6. The 130 sites classified as prehistoric generally fall into the category of lithic scatter or campsite. A few sites are categorized as architectural, habitation, stone quarry, or rockshelter. Other sites may simply consist of an isolated find, usually not considered eligible for the NRHP. Five of the 130 prehistoric sites may also have an historic component. The three historic sites located in the Blue Mesa reach are two steel bridges (5GN1821 at the confluence of Lake Fork and the Gunnison and 5GN1822 at Dillon Mesa, the latter potentially eligible for the NRHP) and a trash scatter (5GN2089) representing a former small ranch settlement, located by the NPS (1990) on a low, partially graded terrace just east of Stevens Creek. All but one of the 67 sites in the Curecanti Archaeological District are 


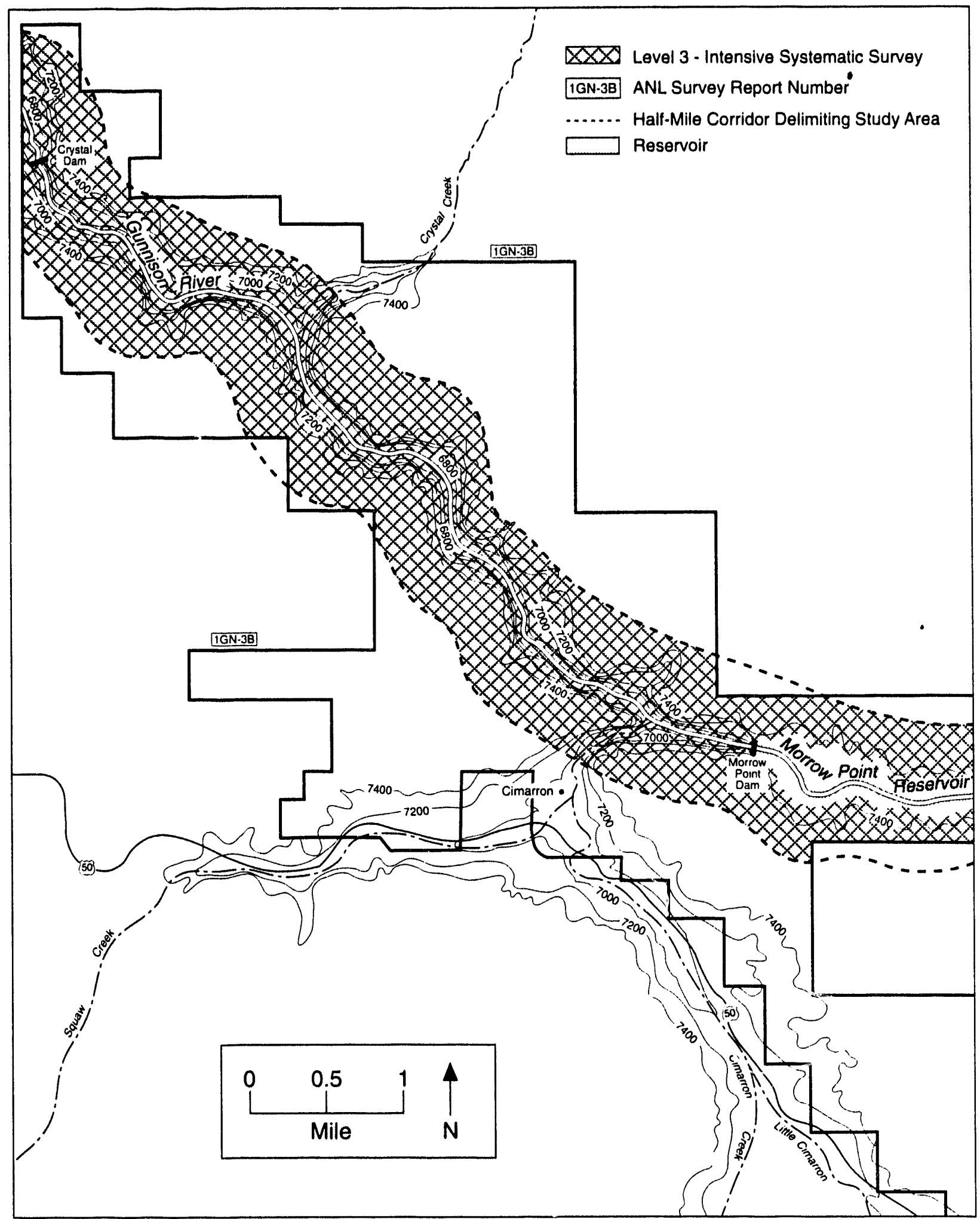

FIGURE 20 Previous Archaeological Surveys: Cimarron and Cathedral Peak 
TABLE 6 Gunnison River: Recorded Sites in Reach 1 (Blue Mesa Reservoir)

\begin{tabular}{|c|c|c|c|c|c|c|}
\hline Site I.D. & Prehistoric & Historic & Site Type & Structures & Features & NRHP Status \\
\hline $5 \mathrm{GN} 1$ & Yes & No & $\begin{array}{l}\text { Lithic; stone } \\
\text { quarry }\end{array}$ & None & Lithic scatter & Within NR District \\
\hline 5GN2 & Yes & No & Lithic & None & Lithic scatter & Field not eligible \\
\hline 5GN3 & Yes & No & Lithic & None & Lithic scatter & Field not eligible \\
\hline 5 GN4 & Yes & No & Lithic & None & Lithic scatter & Field not eligible \\
\hline 5GN5 & Yes & No & Lithic & None & Lithic scatter & Field not eligible \\
\hline 5GN6 & Yes & No & $\begin{array}{l}\text { Lithic; stone } \\
\text { quarry }\end{array}$ & None & Lithic scatter & Field not eligible \\
\hline 5GN7 & Possible & Unknown & Rock art & None & Petroglyphs & Field not eligible \\
\hline 5GN8 & Yes & No & Lithic & None & Lithic scatter & Field not eligible \\
\hline 5GN9 & Yes & No & Lithic & None & Lithic scatter & Field not eligible \\
\hline 5GN10 & Multicomponent & No & $\begin{array}{l}\text { Campsite; lithic } \\
\text { workshop }\end{array}$ & Possible & $\begin{array}{l}\text { Lithic scatter; } \\
\text { hearth; charcoal }\end{array}$ & Within NR District \\
\hline 5GN14 & Yes & No & Lithic & None & Lithic scatter & Within NR District \\
\hline 5GN50 & Yes & No & Lithic & None & Lithic scatter & Within NR District \\
\hline 5GN51 & Yes & Possible & Lithic & None & Lithic scatter & Within NR District \\
\hline 5GN52 & Yes & No & Campsite & None & $\begin{array}{l}\text { Lithic scatter; } \\
\text { mano; metate }\end{array}$ & Undetermined \\
\hline 5GN53 & Protohistoric & No & Ute campsite & None & $\begin{array}{l}\text { Lithic scatter; } \\
\text { burned clay }\end{array}$ & Potentially eligible \\
\hline 5GN54 & Yes & No & Lithic & None & Lithic scatter & Undetermined \\
\hline
\end{tabular}


TABLE 6 (Cont.)

\begin{tabular}{|c|c|c|c|c|c|c|}
\hline Site I.D. & Prehistoric & Historic & Site Type & Structures & Features & NRHP Status \\
\hline 5GN55 & Yes & No & Lithic & None & Lithic scatter & Undetermined \\
\hline 5GN56 & Yes & No & Lithic & None & Lithic scatter & Undetermined \\
\hline 5GN5? & Yes & No & Lithic & None & Lithic scatter & Field not eligible \\
\hline 5GN58 & Yes & No & Lithic & None & Lithic scatter & Undetermined \\
\hline 5GN59 & Yes & No & Lithic & None & Lithic scatter & Field not eligible \\
\hline $5 \mathrm{GN} 60$ & Yes & No & Lithic & None & Lithic scatter & Undetermined \\
\hline 5GN61 & Yes & No & Lithic & None & Lithic scatter & Undetermined \\
\hline 5GN62 & Yes & No & Lithic & None & Lithic scatter & Undetermined \\
\hline 5GN63 & Yes & No & $\begin{array}{l}\text { Lithic quarry } \\
\text { area }\end{array}$ & None & Lithic scatter & Field not eligible \\
\hline 5GN65 & Yes & No & Campsite & None & $\begin{array}{l}\text { Lithic scatter; } \\
\text { possible hearth }\end{array}$ & Undetermined \\
\hline 5GN66 & Yes & No & Campsite & None & $\begin{array}{l}\text { Lithic; ground- } \\
\text { stone scatter; } \\
\text { possible hearth }\end{array}$ & Undetermined \\
\hline 5GN67 & Late Prehistoric & No & Lithic & None & Lithic scatter & Undetermined \\
\hline 5GN68 & Yes & No & Lithic & None & Lithic scatter & Undetermined \\
\hline 5GN70 & Yes & No & Lithic & None & Lithic scatter & Undetermined \\
\hline 5GN71 & Yes & No & Lithic & None & Lithic scatter & Undetermined \\
\hline 5GN72 & Yes & No & Lithic & None & $\begin{array}{l}\text { Lithic scatter; } \\
\text { hearth }\end{array}$ & Undetermined \\
\hline
\end{tabular}


TABLE 6 (Cont.)

\begin{tabular}{|c|c|c|c|c|c|c|}
\hline Site I.D. & Prehistoric & Historic & Site Type & Structures & Features & NRHP Status \\
\hline 5GN73 & Yes & No & Lithic & None & Lithic seatter & Undetermined \\
\hline 5GN74 & Yes & No & Lithic & None & Lithic scatter & Undetermined \\
\hline 5 GN75 & Yes & No & Lithic & None & Lithic scatter & Undetermined \\
\hline 5GN76 & Yes & No & Lithic & None & Lithic scatter & Undetermined \\
\hline 5 GN129 & Yes & No & Lithic & None & Lithic scatter & Undetermined \\
\hline 5 GN130 & Yes & No & Campsite & None & Lithic scatter & Within NR District \\
\hline 5 GN131 & Yes & No & Campsite & None & Lithic scatter & Within NR Distrigt \\
\hline 5GN132 & Yes & No & Lithic & None & Lithic scatter & Within NR District \\
\hline 5GN133 & Yes & No & Campsite & None & Lithic scatter & Within NR District \\
\hline 5 GN134 & Yes & No & Campsite & None & Lithic scatter & Within NR District \\
\hline 5GN135 & Yes & No & Lithic & None & Lithic scatter & Within NR District \\
\hline 5GN136 & Yes & No & Lithic & None & Lithic scatter & Within NR District \\
\hline 5 GN137 & Yes & No & Campsite & None & Lithic scatter & Within NR District \\
\hline 5 GN138 & Yes & No & Campsite & None & Lithic scatter & Within NR District \\
\hline 5 GN139 & Yes & No & Campsite & None & $\begin{array}{l}\text { Lithic scatter; } \\
\text { hearth }\end{array}$ & Within NR District \\
\hline 5 GN140 & Yes & No & Campsite & None & Lithic scatter & Within NR District \\
\hline 5 GN141 & Yes & No & Campsite & None & $\begin{array}{l}\text { Lithic scatter; } \\
\text { hearths }\end{array}$ & Within NR District \\
\hline
\end{tabular}




\section{TABLE 6 (Cont.)}

\begin{tabular}{|c|c|c|c|c|c|c|}
\hline Site I.D. & Prehistoric & Historic & Site Type & Structures & Features & NRHP Status \\
\hline 5GN142 & Yes & No & Campsite & None & $\begin{array}{l}\text { Lithic scatter; } \\
\text { hearth }\end{array}$ & Within NR District \\
\hline 5 GN143 & Yes & No & Lithic & None & Lithic scatter & Within NR District \\
\hline 5GN145 & Yes & No & Lithic & None & Lithic scatter & Undetermined \\
\hline 5 GN146 & Yes & No & Lithic & None & Lithic scatter & Undetermined \\
\hline 5GN147 & Yes & No & Lithic & None & Lithic scatter & Within NR District \\
\hline 5GN148 & Yes & No & Lithic & None & Lithic scatter & Within NR District \\
\hline 5GN149 & Yes & No & Campsite & None & $\begin{array}{l}\text { Lithic scatter; } \\
\text { mano }\end{array}$ & Within NR District \\
\hline 5GN150 & Yes & No & Lithic & None & Lithic scatter & Within NR District \\
\hline 5 GN162 & Yes & No & Lithic & None & Lithic scatter & Within NR District \\
\hline 5GN163 & Yes & No & Lithic & None & Lithic scatter & Within NR District \\
\hline 5 GN164 & Yes & No & Campsite & None & $\begin{array}{l}\text { Hearths; burned } \\
\text { clay }\end{array}$ & Within NR District \\
\hline $5 \mathrm{GN} 170$ & Yes & Possible & Lithic & None & Lithic scatter & Within NR District \\
\hline 5GN171 & Yes & Possible & Campsite & None & Lithic scatter & Within NR District \\
\hline 5 GN172 & Yes & No & Lithic & None & Lithic scatter & Undetermined \\
\hline 5GN173 & Yes & No & Lithic & None & Lithic scatter & Undetermined \\
\hline $5 \mathrm{GN} 174$ & Yes & Possible & Lithic & None & Lithic scatter & Within NR District \\
\hline 5 GN175 & Yes & No & Campsite & None & Lithic scatter & Within NR District \\
\hline
\end{tabular}


TABLE 6 (Cont.)

\begin{tabular}{|c|c|c|c|c|c|c|}
\hline Site I.D. & Prehistoric & Historic & Site Type & Structures & Features & NRHP Status \\
\hline $5 \mathrm{GN} 176$ & Yes & No & Lithic & None & Lithic scatter & Within NR District \\
\hline $5 \mathrm{GN} 177$ & Yes & No & Lithic & None & Lithic scatter & Within NR District \\
\hline 5 GN181 & Yes & No & Lithic & None & Lithic scatter & Undetermined \\
\hline 5 GN182 & Yes & No & Lithic & None & Lithic scatter & Undetermined \\
\hline 5GN183 & Yes & No & Lithic & None & Lithic scatter & Undetermined \\
\hline $5 \mathrm{GN} 184$ & Yes & No & Lithic & None & Lithic scatter & Undetermined \\
\hline 5GN185 & Yes & No & Campsite & None & Lithic scatter & Undetermined \\
\hline 5GN187 & Yes & No & Lithic & None & Lithic scatter & Undetermined \\
\hline 5GN188 & Yes & No & Lithic & None & Lithic scatter & Undetermined \\
\hline 5GN189 & Yes & No & Lithic & None & Lithic scatter & Undetermined \\
\hline 5GN190 & Yes & No & Lithic & None & Lithic scatter & Undetermined \\
\hline $\begin{array}{l}\text { 5GN191; Kezar } \\
\text { Basin Site }\end{array}$ & $\begin{array}{l}\text { Paleo-Indian } \\
\text { (Plano); Archaic }\end{array}$ & No & $\begin{array}{l}\text { Habitation; } \\
\text { campsite }\end{array}$ & None & $\begin{array}{l}\text { Hearths; baking } \\
\text { pits; extensive } \\
\text { lithic scatter; } \\
\text { faunal remains }\end{array}$ & Within NR District \\
\hline $5 G N 192$ & Yes & No & Lithic & None & Lithic scatter & Undetermined \\
\hline 5GN193 & Yes & No & Lithi. & None & Lithic scatter & Undetermined \\
\hline 5GN196 & Yes & No & Campsite & None & $\begin{array}{l}\text { Lithic scatter; } \\
\text { hearths }\end{array}$ & Within NR District \\
\hline 5GN198 & Yes & No & Lithic & None & Lithic scatter & Within NR District \\
\hline 5GN199 & Yes & No & Campsite & None & Lithic scatter & Within NR District \\
\hline
\end{tabular}


TABLE 6 (Cont.)

\begin{tabular}{|c|c|c|c|c|c|c|}
\hline Site I.D. & Prehistoric & Historic & Site Type & Structures & Features & NRHP Status \\
\hline 5GN200 & Yes & No & Campsite & None & $\begin{array}{l}\text { Lithic scatter; } \\
\text { possible hearth }\end{array}$ & Within NR District \\
\hline 5GN201 & Yes & No & $\begin{array}{l}\text { Campsite; stone } \\
\text { quarry }\end{array}$ & None & Lithic scatter & Within NR District \\
\hline 5GN202 & Yes & No & Campsite & None & $\begin{array}{l}\text { Lithic scatter; } \\
\text { mano; metate }\end{array}$ & Within NR District \\
\hline 5GN203 & Yes & No & Lithic & None & $\begin{array}{l}\text { Lithic scatter; } \\
\text { mano }\end{array}$ & Within NR District \\
\hline 5GN204/205 & Yes & No & Campsite & Stone alignment & $\begin{array}{l}\text { Lithic scatter; } \\
\text { hearths; midden; } \\
\text { ash-charcoal; } \\
\text { burned clay }\end{array}$ & Within NR District \\
\hline 5GN206 & Yes & No & Campsite & None & $\begin{array}{l}\text { Hearths; faunal } \\
\text { remains }\end{array}$ & Within NR District \\
\hline 5GN207 & Yes & No & Campsite & None & $\begin{array}{l}\text { Lithic scatter; } \\
\text { burned rock; } \\
\text { charcoal }\end{array}$ & Within NR District \\
\hline 5GN208 & Yes & No & Lithic & None & $\begin{array}{l}\text { Lithic scatter; } \\
\text { burned rock }\end{array}$ & Within NR District \\
\hline 5GN209 & Yes & No & Lithic & None & Lithic scatter & Within NR District \\
\hline 5GN210 & Yes & No & Campsite & None & $\begin{array}{l}\text { Lithic scatter; } \\
\text { possible hearths; } \\
\text { charcoal }\end{array}$ & Within NR District \\
\hline 5GN211 & Yes & No & Lithic & None & $\begin{array}{l}\text { Possible } \\
\text { subsurface }\end{array}$ & Undetermined \\
\hline
\end{tabular}


TABLE 6 (Cont.)

\begin{tabular}{|c|c|c|c|c|c|c|}
\hline Site I.D. & Prehistoric & Historic & Site Type & Structures & Features & NRHP Status \\
\hline 5GN212 & $\begin{array}{l}\text { Paleo-Indian; } \\
\text { Archaic; Late } \\
\text { Prehistoric }\end{array}$ & No & $\begin{array}{l}\text { Habitation; } \\
\text { campsite }\end{array}$ & None & $\begin{array}{l}\text { Hearths; lithic } \\
\text { scatters; human } \\
\text { bone; clay } \\
\text { figurines }\end{array}$ & Within NR District \\
\hline $5 G N 213$ & Yes & No & Lithic & None & Lithic scatter & Within NR District \\
\hline 5GN214 & Yes & No & Lithic & None & Lithic scatter & Within NR District \\
\hline 5GN215 & Yes & No & Campsite & None & $\begin{array}{l}\text { Lithic scatter; two } \\
\text { manos }\end{array}$ & Within NR District \\
\hline 5GN216 & Yes & No & Lithic & None & Lithic scatter & Within NR District \\
\hline 5GN217 & Yes & No & Campsite & None & $\begin{array}{l}\text { Lithic scatter; } \\
\text { mano; firepits }\end{array}$ & Within NR District \\
\hline 5GN218 & Yes & No & Lithic & None & Lithic scatter & Within NR District \\
\hline 5GN219 & Yes & No & Lithic & None & Lithic scatter & Within NR District \\
\hline $5 \mathrm{GN} 220$ & Yes & No & Lithic & None & Lithic scatter & Within NR District \\
\hline 5GN221 & Yes & Unknown & Campsite & None & Lithic scatter & Within NR District \\
\hline 5GN222 & Archaic; Ute & Yes & Campsite & None & $\begin{array}{l}\text { Lithic scatter; } \\
\text { charcoal or ash; } \\
\text { hearths; quarry } \\
\text { area }\end{array}$ & $\begin{array}{l}\text { Within NR District; } \\
\text { eligible }\end{array}$ \\
\hline 5 GN223 & Paleo-Indian & No & Campsite & None & $\begin{array}{l}\text { Lithic scattei; } \\
\text { possible charcoal } \\
\text { stains }\end{array}$ & Within NR District \\
\hline 5GN224 & Yes & No & Lithic & None & Lithic scatter & $\begin{array}{l}\text { Within NR District; } \\
\text { potentially eligible }\end{array}$ \\
\hline
\end{tabular}


TABLE 6 (Cont.)

\begin{tabular}{|c|c|c|c|c|c|c|}
\hline Site I.D. & Prehistoric & Historic & Site Type & Structures & Features & NRHP Status \\
\hline 5GN225 & Yes & No & Campsite & None & $\begin{array}{l}\text { Lithic scatter; } \\
\text { mano }\end{array}$ & Within NR District \\
\hline 5GN226 & Yes & No & Campsite & None & $\begin{array}{l}\text { Lithic scatter; } \\
\text { mano }\end{array}$ & Within NR District \\
\hline 5 GN230 & Yes & No & Lithic & None & Lithic scatter & Within NR District \\
\hline 5GN231 & Yes & No & Lithic & None & Lithic scatter & Within INR District \\
\hline 5GN247 & $\begin{array}{l}\text { Early; Middle } \\
\text { Archaic }\end{array}$ & No & Campsite & $\begin{array}{l}\text { Possible shade or } \\
\text { brush house }\end{array}$ & $\begin{array}{l}\text { Hearths; fire- } \\
\text { cracked rock } \\
\text { scatter; lithic } \\
\text { scatter; charcoal } \\
\text { or ash; faunal }\end{array}$ & $\begin{array}{l}\text { Within NR District; } \\
\text { potentially eligible }\end{array}$ \\
\hline 5GN256 & Yes & No & Architectural & Stone circle & None & Not eligible \\
\hline 5GN257 & Yes & No & Lithic & None & Lithic scatter & Not eligible \\
\hline 5GN258 & Yes & No & Campsite & None & Several hearths & Not eligible \\
\hline 5GN259 & Yes & No & Lithic & None & Lithic scatter & Not eligible \\
\hline 5GN260 & Yes & No & Lithic & None & Lithic scatter & Not eligible \\
\hline 5GN283 & Yes & Yes & Architectural & $\begin{array}{l}\text { Stone alignment; } \\
\text { cairn }\end{array}$ & None & Undetermined \\
\hline 5GN284 & Yes & No & Lithic & None & Lithic scatter & Undetermined \\
\hline 5GN1267 & Yes & No & Isolated find & None & None & Field not eligible \\
\hline 5GN1268 & Yes & No & Isolated find & None & None & Field not eligible \\
\hline EGN1665 & Yes & No & Campsite & None & $\begin{array}{l}\text { Possible } \\
\text { subsurface }\end{array}$ & Within NR District \\
\hline
\end{tabular}


TABLE 6 (Cont.)

\begin{tabular}{|c|c|c|c|c|c|c|}
\hline Site I.D. & Prehistoric & Historic & Site Type & Structures & Features & NRHP Status \\
\hline 5GN1666 & Late Archaic & No & Lithic & None & Lithic scatter & Undetermined \\
\hline 5GN1168 & Archaic & No & Lithic & None & $\begin{array}{l}\text { Hearths; charcoal } \\
\text { and ash }\end{array}$ & Potentially eligible \\
\hline 5GN1677 & Late Archaic & No & Lithic & None & Lithic scatter & Undetermined \\
\hline 5GN1686 & Protohistoric & Yes & Lithic & None & Lithic scatter & Field not eligible \\
\hline 5GN1729 & Middle Archaic & No & Architectural & Possible & $\begin{array}{l}\text { Possible } \\
\text { subsurface }\end{array}$ & Within NR District \\
\hline 5GN1762 & Yes & No & $\begin{array}{l}\text { Lithic; stone } \\
\text { quarry }\end{array}$ & None & Lithic scatter & $\begin{array}{l}\text { Within NR District; } \\
\text { potentially eligible }\end{array}$ \\
\hline 5 GN1821 & No & Yes & Bridge & Steel bridge & None & Field not eligible \\
\hline 5GN1822 & No & Yes & Bridge & Steel bridge & None & Eligible \\
\hline 5GN1870 & Yes & No & Campsite & None & $\begin{array}{l}\text { Lithic scatter; } \\
\text { hearths; charcoal }\end{array}$ & Within NR District \\
\hline 5GN2089 & No & Yes & Settlement & None & Trash scatter & Within NR District \\
\hline
\end{tabular}


within Reach 1 and are contained in Unit I of the NR District; four of the sites in this district are also potentially eligible for the NRHP on the basis of individual merit. Two additional sites in the reach are potentially eligible for the NRHP.

East of Steuben Creek, in a narrow canyon area at the east end of the reservoir, there are seven sites that are outside of the NR District (Unit I). Approximately 0.5 mi east of Hierro, on the opposite bank of the river near South Beaver Creek, three lithic scatters (5GN129, 5GN72, and 5GN73) are located between 100 and $200 \mathrm{ft}$ above the high-water line. A lithic scatter with potential subsurface features (site 5GN211) is located about 1 mi east of Steuben Creek between 300 and $400 \mathrm{ft}$ above the river. A lithic scatter (5GN1686) and two isolated finds (5GN1267 and 5GN1268) are located 0.5 mi east of the park boundary over $500 \mathrm{ft}$ above the reservoir; none of the three is eligible for the NRHP.

West of Steuben Creek, the canyon widens considerably, allowing the formation of Blue Mesa Reservoir. The reservoir consists of $96 \mathrm{mi}$ of shoreline and numerous tributary creeks. A large concentration of sites surrounds the reservoir. The first cluster of sites (from east to west) is located between Steuben Creek to the north and the southern branch of Willow Creek to the south. Fourteen sites (5GN130-143), all comprising lithic scatters and many designated as campsites, are within this area; they are also within the NR District (Unit I). Four of these sites are less than $40 \mathrm{ft}$ above the reservoir, one on the south branch of Willow Creek; site 5GN135 is reported by Jones (1992:4) to be impacted by erosion due to wind-driven wave action.

Ten sites are located on the north side of the reservoir between Steuben Creek and Stevens Creek (5GN196, 5GN213 through 5GN219, 5GN1665, and historic site 5GN2089). Again, all 10 sites contain lithic scatters, except for the previously discussed historic site; four are campsites that are within Unit I of the archaeological district. Three sites (5GN216-218) are located at the confluence of three unnamed creeks with the reservoir, and 5GN196, 5GN219, and 5GN1665 are within $20 \mathrm{ft}$ above the high-water mark as indicated on the USGS topographic map.

Also to the north are four sites between Stevens Creek and the northern branch of Willow Creek (5GN207-210). All of these sites are within the NR District (Unit I) and are less than $40 \mathrm{ft}$ above the water line; site $5 \mathrm{GN} 210$ is at the mouth of Stevens Creek and 5 GN207 is at the mouth of Willow Creek.

On the south side of the reservoir between the southern branch of Willow Creek and Kezar Basin are 13 sites, all within the NR District (Unit I). Sites 5GN148, 5GN149, $5 \mathrm{GN} 150,5 \mathrm{GN} 224,5 \mathrm{GN} 225$, and 5GN226 are 800 to $1,200 \mathrm{ft}$ above the reservoir; the other seven sites are within $80 \mathrm{ft}$ above the water line. Site 5 GN147 is near the mouth of Willow Creek, and 5GN212 is halfway between Willow Creek and Kezar Basin at the mouth of an unnamed tributary. Site 5GN212 is a habitation/campsite with an occupation history spanning the Paleo-Indian to Late Prehistoric periods; it has been heavily disturbed by modern development in the area (Jones 1982:96). Sites 5GN162, 5GN163, and 5GN164 are clustered on the east side of Kezar Basin and are less than $20 \mathrm{ft}$ above the reservoir; 5GN163 is on an extremely small island. Site 5GN164 is partially submerged, subject to beach 
erosion, and is frequently visited due to its location in a sheltered bay, which increases the likelihood that artifacts are being collected (Jones 1992:4). Lithic scatters 5GN230 and 5GN231 are also nearby; the latter is located near a very small unnamed otributary.

From Kezar Basin to Cebolla Creek, 15 sites are recorded south of the reservoir; 13 are within Unit I of the Curecanti Archaeological District. The Blue Mesa Reservoir narrows within this stretch. Sites 5GN174 through SGN177 are 100 to $300 \mathrm{ft}$ above the reservoir; 5GN174 is the closest at approximately $120 \mathrm{ft}$ above the water line, near the mouth of an unnamed tributary. Site 5GN1762 is $140 \mathrm{ft}$ above the same tributary but on the opposite (east) side and farther from the reservoir (approximately $280 \mathrm{ft}$ above the reservoir). However, Site 5GN191 located on Kezar Basin is extremely close to the reservoir and is being significantly affected by it. Also known as the Kezar Basin Site, 5GN191 is a habitation/ campsite originally recorded in 1976 (Stiger 1977) and further examined in 1978 (Euler and Stiger 1981), 1979 (Stiger 1981), 1981 (Jones 1986), and 1991 (Jones 1992). In 1981, over 180 hearths were excavated that were eroding out of the hillside, and a reference datum was established on the intact hillside above the site; investigations in 1991 reported that the datum had eroded away and the observed cutbank may indicate 3 to $5 \mathrm{ft}$ of topsoil erosion caused by wave action (Jones 1992:5). In addition to the erosion impact, site 5GN191 contains many visible surface artifacts that are probably being collected by the numerous visitors, mostly fishermen, who frequent the area via boat or private dirt road (Jones 1992:5). Farther west, as the canyon begins to widen again, sites 5GN170 through 5GN173 are located closer to the reservoir, the latter three less than $40 \mathrm{ft}$ above the water line. Sites $5 \mathrm{GN} 172$ and 5GN173 are outside of the NR District boundary. The remaining five sites in the Kezar Basin-Cebolla Creek area, 5GN3 through 5GN5 (recorded by Lister [1962]) and 5GN259 and 5 GN260 (documented by an unknown source in 1948, according to files at the Colorado Historical Society), are completely submerged by the reservoir.

Twenty-four sites are located north of the reservoir between the northern branch of Willow Creek and East Elk Creek. The majority of the sites are in the NR District (Unit I). Sites 5GN1 and 5GN10 are large sites originally recorded by Lister (1962); 5GN10 extends close to the shoreline near Willow Creek. Site 5GN1729 is an architectural site with possible subsurface features; it is located near the mouth of Willow Creek. South of Willow Creek is an island in the reservoir where site 5GN206 is located. Sites 5GN50 and 5GN51 are lithic scatters 80 to $100 \mathrm{ft}$ above the reservoir west of Dry Creek. Sites 5GN220 through 5GN223 are on either side of Dry Creek, ranging from 20 to $100 \mathrm{ft}$ above the water level; 5GN222 is a large site eligible for the NRHP. Halfway between Willow Creek and Dry Creek is site 5 GN247; it is located very close to the reservoir and is potentially eligible for the NRHP. Sites 5GN198 through 5GN205 are a series of campsites and lithic scatters clustered between East Elk Creek and Haystack Gulch from 40 to $200 \mathrm{ft}$ above the reservoir level. Four sites are outside the archaeological district. Two lithic scatters and a rock alignment (5GN189, $5 \mathrm{GN} 283$, and 5GN284) are over $600 \mathrm{ft}$ above the water level. The fourth site (5GN1870) is at the western district boundary but was not identified until 1986, which excluded it from the nomination of the NR District. This site is exposed to heavy, wind-driven wave action and the resulting cutbank erosion, and it is also located at the edge of a campground where eroding artifacts are probably picked up by campers (Jones 1992:7). 
Also on the north side of Blue Mesa Reservoir, sites 5GN52 through 5GN55 are located between East Elk Creek and Dry Gulch. Site 5GN53 is a Ute camp that is potentially eligible for the NRHP. Sites 5GN56 through 5GN59, 5GN193 and 5GN1666 are lithic scatters between Dry Gulch and Red Creek; two of these sites are not considered eligible for the NRHP. Site 5GN57 is the only site relatively close to the reservoir, being located at the mouth of Dry Gulch; the others are 80 to $400 \mathrm{ft}$ above the high water mark. Between Red Creek and West Elk Creek, sites 5GN60, 5GN61, and 5GN62 are 200 to $350 \mathrm{ft}$ above the reservoir. Sites 5GN63, 5GN1677, and 5GN1668 are near Dillon Pinnacles, the former two between 300 and $400 \mathrm{ft}$ above the high water mark and the latter on the Dillon Gulch tributary at an elevation of about $80 \mathrm{ft}$ above the reservoir. Sites 5GN63 and 5GN1668 are eligible for the NRHP. Submerged sites 5GN2 and 5GN8 and historic bridge 5GN1822 are also withir the area between Red and West Elk creeks.

On the south, sites 5GN181 through 5GN185 are located between Cebolla Creek and Fourmile Gulch; 5GN181 is a partially inundated lithic scatter. Site 5GN71 is an undisturbed lithic scatter located west of the mouth of Fourmile Gulch at about a 20 -ft elevation above the water line. Site 5GN70, also an undisturbed lithic scatter, is on the west bank of an unnamed tributary due south of the West Elk Creek and Soap Creek confluences into the reservoir. Four additional lithic scatters (5GN187, 5GN188, 5GN190, and 5GN192) are located east of the Lake Fork of the Gunnison about 300 to $400 \mathrm{ft}$ above the river level. No sites are recorded on the west side of this river; historic bridge 5GN1821 crosses over the river less than $2 \mathrm{mi}$ east of Blue Mesa Dam. Site 5GN256 is inundated, but located near the pre-dam confluence of the Gunnison and the Lake Fork of the Gunnison.

In the relatively small area between West Elk Creek and Soap Creek, six sites have been recorded; four of these are completely inundated (5GN6, 5GN7, 5GN9, and 5GN258). Sites 5GN145 and 5GN146 are lithic scatters located halfway between the two creeks, approximately 80 to $100 \mathrm{ft}$ above the reservoir level.

The area between Soap Creek and Blue Mesa Dam contains eight recorded sites. Lithic scatters 5GN74 through 5GN76 are located along a small unnamed tributary just west of Soap Creek. Sites 5GN65 through 5GN68, two lithic scatters and two campsites, are widely dispersed along the west side of the reservoir north of the dam, 100 to $300 \mathrm{ft}$ above the water line. Site 5GN257 is completely submerged.

\subsubsection{Reach 2: Blue Mesa Dam to Morrow Point Dam}

Eleven sites are located along the Gunnison River below Blue Mesa Reservoir within Reach 2 of the study area (Table 7). One site is potentially eligible for the NRHP and is currently listed within the NR District.

The site closest to the dam is site 5 GN255, a rockshelter about $400 \mathrm{ft}$ above the river

on the south side between the dam and Pine Creek. The next sites are 3 to 5 mi downstream (5GN64 and 5GN195); they are just within the 0.5-mi boundary to the north and well over 
TABLE 7 Gunnison River: Recorded Sites in Reach 2 (Blue Mesa Dam to Morrow Point Dam)

\begin{tabular}{|c|c|c|c|c|c|c|}
\hline Site I.D. & Prehistoric & Historic & Site Type & Structures & Features & NRHP Status \\
\hline $5 \mathrm{GN} 20 \mathrm{a}$ & Yes & No & Lithic & None & Lithic scatter & Undetermined \\
\hline $5 G N 20 b$ & Yes & No & Lithic & None & Lithic scatter & Undetermined \\
\hline $5 \mathrm{GN} 41$ & Protohistoric & No & Campsite & None & $\begin{array}{l}\text { Lithic; ceramic } \\
\text { scatter; faunal } \\
\text { remains }\end{array}$ & $\begin{array}{l}\text { Within NR District; } \\
\text { Potentially eligible }\end{array}$ \\
\hline $5 \mathrm{GN} 64$ & Yes & No & Lithic & None & Lithic scatter & Undetermined \\
\hline 5GN195 & Yes & No & Lithic & None & $\begin{array}{l}\text { Lithic scatter; } \\
\text { grinding stone }\end{array}$ & Undetermined \\
\hline $5 G N 255$ & Yes & No & Rockshelter & None & Unknown & Undetermined \\
\hline $5 \mathrm{GN} 265$ & Yes & No & Campsite & None & Ash-charcoal & Undetermined \\
\hline 5GN1032 & Yes & No & Isolated find & None & Debitage & Field not eligible \\
\hline 5GN1033 & Yes & No & Isolated find & None & Projectile point & Field not eligible \\
\hline 5GN1676 & Archaic & No & Lithic & None & Lithic scatter & Undetermined \\
\hline 5GN1766 & No & Late $1800 \mathrm{~s}$ & Curecanti Railroad Depot & Multiple & 2 privies & Undetermined \\
\hline
\end{tabular}


$800 \mathrm{ft}$ above the river. Site $5 \mathrm{GN} 1676$ is located about the same distance from the dam as 5GN195 but is closer to the river; however, this lithic scatter is still over $400 \mathrm{ft}$ above the river. Only one historic site occurs in this reach, site 5GN1766, or the Curecanti Railroad Depot; it is located on the opposite bank of the confluence of Blue Creek with the Gunnison. The depot site consists of multiple structures (depot, platform, chicken house, section house, bunkhouse, and office) and dates to the late 1800s. Also in this vicinity, but at a much higher elevation, is site 5GN41 - a single-component, protohistoric, Ute-Numic campsite just west of Pioneer Lookout Point. The Ute-Numic site, dating from around the time of EuroAmerican contact, is within the NR District (Unit III), but may also be eligible for NRHP status because it is the first occupation in Curecanti Park that can be linked to the Numic speakers (Jones 1986:17). Sites 5GN20a and 5GN20b, two lithic scatters well above the river (over 1,000 ft), are located within $1 \mathrm{mi}$ downstream of the depot. A prehistoric campsite (5GN265) is located approximately 2 mi downstream of the depot, near the mouth of a small unnamed tributary. Two isolated finds (5GN1032 and 5GN1033) were also discovered approximately $0.5 \mathrm{mi}$ east of Cimarron Creek along the north side of the river; neither would be eligible for the NRHP.

\subsubsection{Reach 3: Morrow Point Dam to Crystal Dam}

No known sites have been recorded within Reach 3, primarily because of the steep canyon topography, the pre-dam 5,000- to 7,000-cfs flow of the river, and the lack of suitable floodplain. One area that may have potentially contained artifactual material is the area near Crystal Dam, but it was surveyed after dam construction had already begun and any evidence of past occupation had already been destroyed (Breternitz 1974). 


\section{REFERENCES}

Aikens, M.C., 1978, Hogup Cave, University of Utah Anthropological Papers No. 87, Salt Lake City, Utah.

Aikens, C.M., 1983, "The Far West," in Ancient North Americans, 2nd ed., W.H. Freeman and Company, New York, N.Y., pp. 149-202.

Aikens, C.M., and D.B. Madsen, 1986, "Prehistory of the Eastern Area," in Handbook of North American Indians, Volume 11: Great Basin, W.L. D'Azevedo (editor), Smithsonian Institution, Washington, D.C., pp. 149-160.

Armitage, C.L., et al., 1982, The Deadman Wash Site, Cultural Resource Management Report No. 6, Archaeological Services, Western Wyoming College, Rock Springs, Wyo.

Auerbach, H.S. (editor), 1943, "Father Escalante's Journal with Related Documents and Maps," Utah Historical Quarterly 11:41-42.

Baker, J.H., and L.R. Hafen, 1927, History of Colorado, Vols. 1-3, Linerman Co., Inc., Denver, Colo.

Beck, W.A., 1962, New Mexico; A History of Four Centuries, University of Oklahoma Press, Norman, Okla.

Billat, S.E., 1990, An Archaeological Inventory of One Seismic Line on Goslin Mountain and in Clay Basin in Daggett County, Utah, Technical Series No.90-18, Brigham Young University Museum of Peoples and Cultures, Brigham Young University, Provo, Utah, Sept. 4.

Blackwelder, E., 1950, "Pleistocene Geology, the Green River Basin, Wyoming," in Fifth Annual Field Conference Guidebook, Wyoming Geological Association, pp. 81-85.

BLM: see Bureau of Land Management.

Breternitz, D.A., 1965, Archaeological Survey in Dinosaur National Monument, ColoradoUtah, 1963-1964, U.S. National Park Service, U.S. Department of the Interior, and the University of Colorado, Boulder, Colo., May.

Breternitz, D.A., 1970, Archaeological Excavations in Dinosaur National Monument, Colorado-Utah, 1964-1965, University of Colorado Studies, Series in Anthropology No. 17, University of Colorado Press, Boulder, Colo., Aug.

Breternitz, D.A., 1974, Report of Archaeological Reconnaissance, Crystal Dam and Reservoir, Montrose County, Colorado, letter report, Archaeological Research Center, University of Colorado, Mesa Verde National Park, Cortez, Colo., July 5. 
Buckles, W., 1964, Archaeological Survey of the Morrow Point Dam Area, Montrose and Gunnison Counties, Colorado, report on file, Midwest Archaeological Center, National Park Service, U.S. Department of the Interior, Lincoln, Neb., Nov. 6.

Bureau of Land Management, 1980, Proposed Domestic Livestock Grazing Management Program in the Gunnison Basin Resource Area and Silverton Planning Unit, Montrose District, Colorado, Draft Environmental Impact Statement, U.S. Department of the Interior, Montrose, Colo.

Bureau of Land Management, 1986, Oregon/Mormon Pioneer National Historic Trails Management Plan, U.S. Department of the Interior, Washington, D.C., U.S. Government Printing Office No. 1988-573-065/60080, May.

Burroughs, J.R., 1962, Where the Old West Stayed Young, William Morrow and Company, New York, N.Y.

Callaway, D.G., et al., 1986, "Ute," in Handbook of North American Indians, Vol. XI: Great Basin, Smithsonian Institution Press, Washington, D.C., pp. 336-367.

Cassells, E.S., 1983, The Archaeology of Colorado, Johnson Books, Boulder, Colo.

Chittenden, H.M., 1954, The Fur Trade of the Far West, Vols. 1 and 2, Academic Reprints, Stanford, Calif.

Chronic, H., 1980, Roadside Geology of Colorado, Mountain Press Publishing Co., Missoula, Mont.

Cook, C.W., 1981, Archaeological Reconnaissance of the Clay Basin Seismic Project, Browns Park, Daggett County, Utah, prepared by Utah Archaeological Research Corporation for Engineering Specialties Inc. (Federal Permit \#81-UT-181), Aug.

Cordell, L.S., 1984, Prehistory of the Southwest, Academic Press, Orlando, Calif.

Creasman, S.D., 1985a, PLT Engineering, Inc., Borrow Area, Western Wyoming College, Rock Springs, Wyo., May 3.

Creasman, S.D., 1985b, PLT Engineering, Inc., Extra Right-of-Way Width for Cheuron's $\mathrm{CO}_{2} / \mathrm{PO}_{4}$ Pipeline Corridors, Western Wyoming College, Rock Springs, Wyo., July 1.

Day, K.C., and D.S. Dibble, 1963, Archaeological Survey of the Fla1.iing Gorge Reservoir Area, Wyoming-Utah, University of Utah Anthropological Papers No. 65, Salt Lake City, Utah.

Delaney, R.W., 1989, The Ute Mountain Utes, University of New Mexico Press, Albuquerque, N.M.

Dorset, P.F., 1970, The New Eldorado: The Story of Colorado's Gold and Silver Rushes, Macmillan, London. 
Drager, D.L., and A.K. Ireland, 1986, The Seedskadee Project: Remote Sensing in Non-Site Ar'chaeology, National Park Service, Southwest Region, Albuquerque, N.M., and the Bureau of Reclamation, Salt Lake City, Utah.

Eddy, F.W., et al., 1982, The Archaeological Mitigation Program and Excavations at Site 5MF605, Browns Park National Wildlife Refuge, Moffat County, Colorado, prepared by Science Applications, Inc., Boulder, Colo., for the National Park Service, U.S. Department of the Interior, March.

Euler, R.T., and M.A. Stiger, 1981, 1978 Test Excavations at Five Archaeological Sites in Curecanti National Recreation Area, Intermountain Colorado, Bureau of Anthropological Research, University of Colorado, Boulder, Colo.

Fairley, H.C., et al., 1991, The Grand Canyon River Corridor Survey Project: Archaeological Survey along the Colorado River between Glen Canyon Dam and Separation Canyon, National Park Service, U.S. Department of the Interior.

Fenneman, N.M., 1931, Physiography of the Western United States, McGraw-Hill Book Company, Inc., New York, N.Y.

Fike, R.E., 1976, "Antiquities Site Inventory Forms for Site 42DA56 and 42DA59," Bureau of Land Management, Vernal District, Vernal, Utah, Sept.

Frisın, G.C., 1978, Prehistoric Hunters of the High Plains, Academic Press, New York.

Fritz, P.S., 1941, Colorado: The Centennial State, Prentice-Hall, Inc., New York.

Grady, J., 1984, Northwest Colorado Prehistoric Context, State Historical Society of Colorado, Denver, Colo.

Grand River Institute, 1978, Intensive Cultural Resources Survey of Dominguez Project, Vol. 1, prepared by Grand River Institute, Grand Junction, Colo., for U.S. Department of the Interior, Bureau of Reclamation, Washington, D.C.

Grand River Institute, 1980, Cultural Resources Inventory of the Grand Valley Gas Play Mainline Gathering System for Southwest Gathering Company, Inc., prepared by Grand River Institute, Grand Junction, Colo., for Bureau of Land Management District Offices at Grand Junction and Montrose, Colo.

Guthrie, M.R., et al., 1984, Colorado Mountains Prehistoric Context, State Historical Society of Colorado, Denver, Colo.

Hafen, L.R. (editor), 1948, Colorado and Its People: A Narrative of Topical History of the Centennial State, Vol. 1, Lewis Historical Publishing Co., New York.

Hafen, L.R., 1972, The Mountain Men and the Fur Trade of the Far West, Arthur H. Clark Company, Glendale, Calif. 
Hafen, L.R., et al., 1970, Western America: The Exploration, Settlement, and Develi,, ment of the Region beyond the Mississippi, 3rd ed., Prentice-Hall, Inc., Englewood Cliffs, N.J.

Hagie, C.E., 1931, "Gunnison in the Early Days," The Colorado Magazine 8(4):121-129.

Hansen, S., 1980, Browns Park National Wildlife Refuge Survey, Bureau of Land Management, Craig District Office, Craig, Colo.

Hansen, W.R., 1965, Geology of the Flaming Gorge Area, Utah-Colorado-Wyoming, U.S. Geological Survey Professional Paper 490.

Hansen, W.R., 1971, "Geologic Map of the Black Canyon of the Gunnison River and Vicinity, Western Colorado," Miscellaneous Geologic Investigations, Map I-584, Washington, D.C.

Hansen, W.R., 1975, The Geologic Story of the Uinta Mountains, U.S. Government Printing Office, Washington, D.C.

Hansen, W.R., 1987, The Black Canyon of the Gunnison in Depth, Southwest Parks and Monuments Association, Tucson, Ariz.

Harper, B., 1978, Cultural Resource Survey of O.D. Ignacio to Sumas Line, Dagget County, Utah, prepared by Department of Anthropology, University of Ułah, Salt Lake City, Utah, for Northwest Pipeline Corporation (Antiquities Act Permit 77-UT-081), May.

Harrell, L.L., and S.T. McKern, 1986, The Maxon Ranch Site: Archaic and Late Prehistoric Habitation in Southwest Wyoming, Cultural Resource Management Report No. 18, Archaeological Services, Western Wyoming College, Rock Springs, Wyo.

Hart, G.T., 1874, "Appraisal of Confederated Ute Indian Lands," Indian Claims Commission Docket No. 327, 1974 reprint by Garland Publishing, Inc., New York, N.Y.

Hickman, B.J., 1984, A Cultural Resource Investigation of Seedskadee National Wildlife Refuge Expansion in Sweetwater County, Wyoming, Repurt WY-51-83, prepared by Wyoming Recreation Commission, Office of the Wyoming State Archaeologist, Laramie, Wyo., for U.S. Fish and Wildlife Service, Region VI, Lakewood, Colo., Jan.

Hill, J.J., 1930, "Antoine Robidoux, Kingpin in the Colorado River Fur Trade, 1824-1844," The Colorado Magazine 7(4):125-132.

Hoefer, T., and S.D. Creasman, 1986, Class III Cultural Resources Inventory Report for the IGS Stauffer to General Chemical Gas Pipeline, letter report 86-WWC-49, submitted to J. Dallmann, Industrial Gas Service, Rock Springs, Sept. 22.

Hogan, P.F., and L. Sebastian, 1980, "The Variants of the Fremont: A Methodological Evaluation," Antiquities Section Selected Papers 7:13-16. 


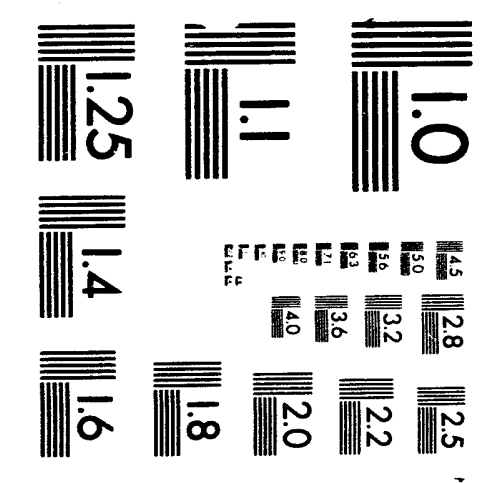



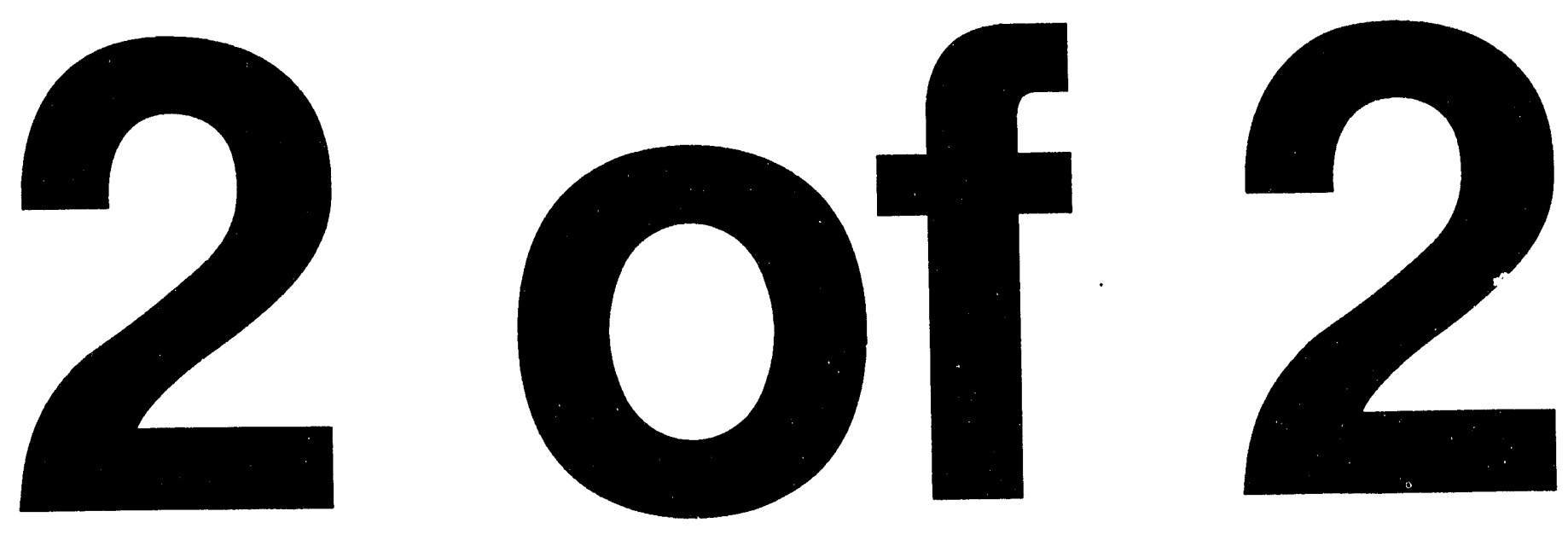
Holmer, R.N., 1978, A Mathematical Typology for Archaic Projectile Points of the Eastern Great Basin, Ph.D. dissertation, University of Utah, Salt Lake City, Utah.

Holmer, R.N., 1979, Final Report: Split Mountain Cultural Study Tract, prepared by University of Utah, Department of Anthropology, Archaeological Center, Salt Lake City, Utah, for Bureau of Land Management, Vernal Utah District, Vernal, Utah.

Horne-Sorenson, M., 1982, "Previous Research and Culture History of Eastern Utah," in Test Excavations: Sixteen Prehistoric Sites along the MAPCO Rocky Mountain Liquid Hydrocarbons Pipeline, Utah and Southwestern Wyoming, L.A. Davenport, R.N. Holmer, and M. Horne-Sorenson (editors), Reports of Investigations No. 80-12, Archaeological Center, Department of Anthropology, University of Utah, Salt Lake City, Utah.

Hughes, J.D., 1977, American Indians in Colorado, Pruett Publishing Company, Boulder, Colo.

Hunter, J.F., 1925, Pre-Cambrian Rocks of the Gunnison River, Colorado, U.S. Geological Survey Bulletin No. 777.

Hunter, W.R., and C.F. Spears, 1975, Soil Survey of the Gunnison Area, Colorado - Parts of Gunnison, Hinsdale, and Saguache Counties, U.S. Soil Conservation Service and the Colorado Agricultural Experiment Station, Denver, Colo., Aug.

Huscher, B.H., and H.A. Huscher, 1943, "The Hogan Builders of Colorado," Southwestern Lore 9:1-92.

Iacovetta, B.A., 1977, Archaeological Survey Report: Dutch John Pinyon-Juniper Conversion Project, Daggett County, Utah, U.S. Department of Agriculture, National Forest Service, Ashley National Forest, Region 4, Flaming Gorge Ranger District, Vernal, Utah, Sept.

Janetski, J.C., 1991, The Ute of Utah Lake, University of Utah Anthropological Papers No. 116, Salt Lake City, Utah.

Jennings, C.H., 1968, "The Paleo-Indian and Archaic Stages in Western Colorado," Southwestern Lore 34(1):11-20.

Jennings, J.D., 1957, Danger Cave, University of Utah Anthropological Papers No. 27, Salt Lake City, Utah.

Jennings, J.D., 1986, "Prehistory: Introduction," in Handbook of North American Indians, Volume 11: Great Basin, W.L. D'Azevedo (editor), Smithsonian Institution, Washington, D.C., pp. 113-119.

Jennings, J.D., 1978, Prehistory of Utah and the Eastern Great Basin, University of Utah Anthropological Papers No. 98, Salt Lake City, Utah. 
Jennings, J.D., 1989, Prehistory of North America, Mayfield Publishing Company, Mountain View, Calif.

Jennings, J.D., and E. Norbeck (editors), 1964, Prehistoric Man in the New World, University of Chicago Press, Chicago, Ill..

Jennings, J.D., et al., 1980, Sudden Shelter, University of Utah Anthropological Papers No. 103, Salt Lake City, Utah.

Johnson, P.B., no date, "National Register of Historic Places Inventory Site Form for Site 42DA211/AS-160," National Forest Service, Region 4, Dutch John, Utah.

Jones, B.A., 1982, The Curecanti Archeological Project: 1980 Investigations in Curecanti National Recreation Area, Midwest Archaeological Center Occasional Studies in Anthropology No. 8, U.S. Department of the Interior, National Park Service, Lincoln, Neb.

Jones, B.A., 1986, The Turecanti Archeological Project: 1981 Investigations in Curecanti National Recreation Area, Colorado, Midwest Archeological Center Occasional Studies in Anthropology No. 14, National Park Service, U.S. Department of the Interior, National Park Service, Lincoln, Neb., Jan. 9.

Jones, B.A., 1992, Curecanti Archeology, letter report from B. Jones (Supervisory Archeologist, Curecanti National Recreation Area, Midwest Archeological Center, National Park Service, U.S. Department of the Interior, Lincoln, Neb.) to K. Moeller (Argonne National Laboratory, Environmental Assessment and Information Sciences Division, Argonne, Ill.), Jan. 9.

Kimball, S.B., 1991, Historic Resource Study: Mormon Pioneer National Historic Trail, National Park Service, U.S. Department of the Interior, Rocky Mountain Regional Office, Denver, Colo.

Kuntz, D.W., et al., 1989, Faults, Fossils, and Canyons: Significant Geologic Features on Public Lands in Colorado, Geologic Advisory Group, Colorado State Office, U.S. Bureau of Land Management, Denver, Colo.

Lamb, S.M., 1958, "Linguistic Prehistory of the Great Basin," International Journal of Linguistics 24(2).

Larralde, S.L., and P.R. Nickens, 1980, Archaeological Inventory in the Red Wash Cultural Study Tract, Uintah County, Utah, prepared by Nickens and Associates, Montrose, Colo., for Bureau of Land Management, U.S. Department of the Interior, March.

Leach, L.L., 1970, Archaeological Investigations at Deluge Shelter in Dinosaur Monument, Ph.D. dissertation, Department of Anthropology, University of Colorado, Boulder, Colo. 
Lennon, T.J., et al., 1980, A Predictive Sample Survey of Cultural Resources within Potential Transmission Corridors for the Mount Emmons Project, Gunnison County, Colorado, prepared by Western Cultural Resources Management, Inc., Boulder, Colo., for Camp, .Dresser, and McKee, Inc., Envircnmental Sciences Division, Denver, Colo., June 20.

Lindsay, L.W., 1986a, Browns Park Chaining Archaeological Survey Preliminary Report, Antiquities Section, Utah Department of State History, Salt Lake City, Utah.

Lindsay, L.W., 1986b, Addendum, Additional Browns Park Chaining Archaeological Survey Preliminary Report, Antiquities Section, Utah Department of State History, Salt Lake City, Utah.

Lister, R.H., 1962, Archaeological Survey of the Blue Mesa Reservoir, Colorado, manuscript on file at the Midwest Archaeological Center, National Park Service, U.S. Department of the Interior, Lincoln, Neb.

Long, C.A., 1965, "The Mammals of Wyoming," University of Kansas Publications 14(18):493-758.

Loosle, B., 1991, Social Interaction among the Late Plains Village Populations in the Central Plains, Ph.D. dissertation, Department of Anthropology, University of Kansas, Lawrence, Kans.

Lowie, R.H., 1924, "Notes on Shoshonean Ethnography," Anthropological Papers of the American Museum of Natural History XX(3):185-314.

Madsen, D.B., and K. Sargent, 1979, An Archaeological Inventory of the Browns Park Land Exchange, U.S. Department of the Interior, Bureau of Land Management, Utah State Office, Salt Lake City, Utah, May 24.

Malouf, C.I., and J. Findlay, 1986, "Euro-American Impact before 1870," in Handbook of North American Indians, Volume 11: Great Basin, W.L. D'Azevedo (editor), Smithsonian Institution, Washington, D.C., pp. 499-516.

Marsh, C.S., 1982, People of the Shining Mountains, Pruett Publishing Company, Boulder, Colo.

Marwitt, J.P., 1970, Median Village and Fremont Culture Regional Variation, University of Utah Anthropological Papers No. 95, Salt Lake City, Utah.

Marwitt, J.P., 1986, "Fremont Cultures," in Handbook of North American Indians, Volume 11: Great Basin, W.L. D’Azevedo (editor), Smithsonian Institution, Washington, D.C., pp. 161172. 
McEnany, T., 1981, Monitoring Report, Spread 5 and 5a, MAPCO Rocky Mountain Liquid Hydrocarbons Pipeline, Report No. 80-22, prepared by Woodward-Clyde Consultants, Walnut Creek, Calif., for University of Utah, Department of Anthropoløgy, Salt Lake City, Utah, March.

McFadden, T., 1978a, A Cultural Resource Survey of the Flaming Gorge Dam Spillway Stairway, U.S. Forest Service, Ashley National Forest, Region 4, Flaming Gorge Ranger District, Vernal, Utah, Aug. 11.

McFadden, T., 1978b, A Cultural Resource Survey of the Northwest Corporation Pipeline Pinyon-Juniper Pushover, U.S. Forest Service, Ashley National Forest, Region 4, Flaming Gorge Ranger District, Vernal, Utah, Nov. 2.

McFadden, T., and A. Worthington, 1978, A Cultural Resource Survey for the Little Hole Campground Expansion and Mann Bench Development, U.S. Forest Service, Ashley National Forest, Region 4, Flaming Gorge Ranger District, Vernal, Utah, Aug. 15.

Mehls, S.F., 1985, Dinosaur National Monument Historical Resources Study, pre ,ared by Western Historical Studies, Inc., Lafayette, Colo., for National Park Service, U.S. Department of the Interior, Rocky Mountain Regional Office, Denver, Colo., July 31.

Metcalf, M.D., et al., 1989, A Class III Cultural Resource Inventory of the Proposed Questar North-South Pipeline, Daggett and Uintah Counties, Utah, prépared by Metcalf Archaeological Consultants, Inc., Eagle, Colo., for Questar Pipeline Company, Salt Lake City, Utah, Jan.

Meyer, J.S., and S.M. Riches, 1979, Cultural Resource Survey, Browns Park National Wildlife Refuge, prepared by Fort Lewis College, Durango, Colo., for U.S. Fish and Wildlife Service, Feb. 8.

Moore, R.A., 1985, An Archaeological Survey of Three Seismic Lines near Dutch John in Ashley National Forest, Daggett County, Utah, prepared by San Juan County Archaeological Research Center and Library, Division of Conservation Archaeology, Farmington, N.M., for Western Geophysical, Inc., Kemmerer, Wyo., Jan. 7.

Morgan, D.L., 1960, "The Ferries of the Forty-Niners, Part III, Section 1: The Green River Ferries," Annals of Wyoming 32(Spring 1960):51-79.

National Park Service, 1986, General Management Plan, Development Concept Plans, Land Protection Plan, and Environmental Assessment - Dinosaur National Monument, Moffat County, Colorado, and Uintah County, Utah, National Park Service, U.S. Department of the Interior, Denver, Colo.

National Park Service, 1990, Recent Archaeological Surveys in Curecanti National Recreation Area, Midwest Archaeological Center, National Park Service, U.S. Department of the Interior, Lincoln, Neb., March 16. 
Newberry Archaeological Services, 1985, "IMACS Archaeological Site Form for 42DA402," recorded by Newberry, Archaeological Services, Western Wyoming College, Rock Springs, Wyo., for PLT Engineering, Inc., Borrow Pit 85-WWC-30a.

Norman, V.G., and D.B. Merrill, 1981, Cultural Resources Survey of the Flaming Gorge Peaking Power Project, MESA CRM Paper No. 4, report prepared by MESA Corporation, Orem, Utah, for Bureau of Reclamation-Upper Colorado Region, Salt Lake City, Utah.

NPS: see National Park Service.

Oprandy, C., 1984, Mann Bench Borrow Site, U.S. Forest Service, Ashley National Forest, Region 4, Flaming Gorge Ranger District, Vernal, Utah, Jan.

Ostrogorsky, M., and M.G. Plew, 1981, Cultural Resource Inventory of the Seedskadee National Wildlife Refuge Fencing Project, Sweetwater County, Wyoming, Project Report No. 7, prepared by Idaho Archaeological Consultants, Boise, Idaho, for U.S. Fish and Wildlife Service, Boise, Idaho.

Purdy, W.M., 1959, An Outline of the History of the Flaming Gorge Area, University of Utah Anthropological Papers No. 37, Salt Lake City, Utah.

Reed, A.D., 1984, West Central Colorado Prehistoric Context, Office of Archaeology and Historic Preservation, Colorado Historical Society, Denver, Colo.

Reed, A.D., 1988, Ute Cultural Chronology, Archaeology of the Eastern Ute: A Symposium, P.R. Nickens (editor), Colorado Council of Professional Archaeologists Occasional Papers No. 1, Mesa College, Grand Junction, Colo.

Schroedl, A.R., 1976, The Archaic of the Northern Colorado Plateau, Ph.D. dissertation, University of Utah, University Microfilms, Ann Arbor.

Schroedl, A.R., 1977, "The Paleo-Indian Period on the Colorado Plateau," Southwestern Lore 43(3):1-9.

Smith, C.S., and S.D. Creasman, 1987, The Taliaferro Site: 5000 Years of Prehistory in Southwest Wyoming, Cultural Resource Management Report No. 35, Archaeological Services, Western Wyoming College, Rock Springs, Wyo., April.

Steward, J.H., 1938, Basin-Plateau Aboriginal Sociopolitical Groups, Bureau of American Ethnology Bulletin No. 120, Washington, D.C.

Stiger, M.A., 1977, Archaeological Inventory and Cultural Assessment, Curecanti National Recreation Area, Colorado, Part II: Documentation, manuscript on file at Midwest Archaeological Center, National Park Service, U.S. Department of the Interior, Lincoln, Neb. 
Stiger, M.A., 1980, Archaeological Inventory and Evaluation of Curecanti Recreation Area, Midwest Archaeological Center Occasional Studies in Anthropology No. 7, Midwest Archaeological Center, National Park Service, U.S. Department of the Interior, Lincoln, Neb.

Stiger, M.A., 1981, 1979 Investigations at Seven Archaeological Sites in Curecanti National Recreation Area, Midwest Archaeological Center, National Park Service, U.S. Department of the Interior, Lincoln, Neb.

Stiger, M.A., and S.L. Carpenter, 1980, Archaeological Survey of Black Canyon of the Gunnison National Monument, Midwest Archaeological Center Occasional Studies in Anthropology No. 7, Midwest Archaeological Center, National Park Service, U.S. Department of the Interior, Lincoln, Neb.

Taylor River Ranger District, 1982, Fossil Ridge Wilderness Study Area, Grand Mesa, Uncompahgre, and Gunnison National Forests, Taylor River Ranger District, Gunnison County, Colo., U.S. Government Printing Office No. 1982-0-580-504/401.

Tennent, W.L., 1981, John Jarvie of Browns Park, Cultural Resource Series No. 7, Bureau of Land Management State Office, Salt Lake City, Utah.

Truesdale, J.A., 1991, personal communication from J.A. Truesdale (Dinosaur National Monument, Dinosaur, Colo.) to K. Moeller and L. Malinowski (Argonne National Laboratory, Environmental Assessment and Information Sciences Division, Argonne, Ill.), Sept. 16.

Truesdale, J.A., et al., 1989, Archaeological Investigations along the Echo Park Road, Dinosaur National Monument, Moffat County, Colorado, National Park Service, Rocky Mountain Region, Dinosaur National Monument, U.S. Department of the Interior, Dinosaur, Colo., July 7.

Tucker, C.G., 1974, "Antiquities Site Inventory Form for Site 42DA40," Bureau of Land Management, Vernal District, Vernal, Utah, Jan. 11.

Tucker, C.G., 1976, "Antiquities Site Inventory Form for Site 42DA52," Bureau of Land Management, Vernal District, Vernal, Utah, July 21.

Tucker, G.C., 1986, Results of Archaeological Investigations along the Cheuron $\mathrm{CO}_{2} / \mathrm{PO}_{4}$ Pipelines in Northeastern Utah and Northwestern Colorado, prepared by Nickens and Associates, Montrose, Colo., for Woodward-Clyde Consultants, Walnut Creek, Calif., June.

Upper Colorado Region State-Federal Inter-Agency Group, 1971, "Characteristics of Lands, Appendix 6: Soils," in Volume 6, Upper Colorado Region Comprehensive Framework Study, Ogden, Utah.

U.S. Forest Service, 1978, East River Land Management Plan Final Environmental Impact Statement 76-02, USDA-FS-R2-FEIS, FY-76-02, U.S. Department of Agriculture, Denver, Colo. 
U.S. Forest Service, 1982, Draft Environmental Impact Statement for the Proposed Grand Mesa, Uncompahgre, and Gunnison National Forests Land and Resource Management Plan, Report 02-04-82-05, U.S. Department of Agriculture, Delta, Colo.

USFS: see U.S. Forest Service.

Watts, H.K., 1977, Archaeological Survey Report: Dutch John Pinyon-Juniper Conversion Project, Daggett County, Utah, U.S. Forest Service, Ashley National Forest, Region 4, Flaming Gorge Ranger District, Vernal, Utah, July.

Webb, R., 1986, If We Had a Boat: Green River Explorers, Adventurers, and Runners, University of Utah Press, Salt Lake City, Utah.

Weber, D.A., 1991, Cultural Resources Survey of Part of the Gunnison State Wildlife Area, Gunnison County, Colorado, Colorado Division of Wildlife, Denver, Colo., March.

Willey, G.R., and P. Phillips, 1958, Method and Theory in American Archaeology, University of Chicago Press, Chicago, Ill.

Wilson, L., et al., 1968, Arable Land Resources of Utah, Utah Resources Series No. 42, Utah Agriculture Experiment Station, Utah State University, Logan, Utah.

Woodbury, A.M., 1962, Ecological Studies of the Flora and Fauna of the Curecanti Reservoir Basins, Western Colorado, University of Utah Anthropological Papers No. 59, Salt Lake City, Utah.

Woodward-Clyde Consultants, 1982, Test Excavations: Sixteen Prehistoric Sites along the MAPCO Rocky Mountain Liquid Hydrocarbons Pipeline, Utah and Southwestern Wyoming, L.A. Davenport et al., pp. 7-13, Reports of Investigations 80-12, Archaeological Center, Department of Anthropology, University of Utah, Salt Lake City, Feb.

Woodward-Clyde Consultants, 1983, Cultural Resource Management Program: MAPCO's Rocky Mountain Liquid Hydrocarbons Pipeline, prepared by Woodward-Clyde Consultants, Walnut Creek, Calif., for MAPCO, Inc., Rock Springs, Wyo., March.

Woodward-Clyde Consultants, 1985, Cultural and Paleontological Resource Inventory Investigations along the Cheuron Carbon Dioxide and Phosphate Slurry Pipeline Corridors, Colorado, Utah, and Wyoming, prepared by Woodward-Clyde Consultants, Walnut Creek, Calif., for Chevron U.S.A. Inc., San Francisco, Calif., Jan. 21. 


\section{LIST OF CONTRIBUTORS}

\begin{tabular}{|c|c|c|}
\hline Name & Education/Experience & Specialization/Contribution \\
\hline John F. Hoffecker & $\begin{array}{l}\text { Ph.D., Anthropology; } 17 \text { years } \\
\text { experience in archaeological } \\
\text { research; } 9 \text { years experience } \\
\text { in environmental assessment } \\
\text { archaeology }\end{array}$ & $\begin{array}{l}\text { Prehistoric archaeology; } \\
\text { Sections } 1,2.1,2.2,2.6\end{array}$ \\
\hline Lynn M. Malinowski & $\begin{array}{l}\text { M.A., Anthropology; } 8 \text { years } \\
\text { experience in archaeology; } \\
5 \text { years experience in cultural } \\
\text { resources assessment }\end{array}$ & $\begin{array}{l}\text { North American archaeology; } \\
\text { Sections } 2.4,2.5,3.5 \text {, } \\
\text { references, tables, appendix }\end{array}$ \\
\hline James E. Mathews & M.A., Anthropology & $\begin{array}{l}\text { Prehistoric human ecology; } \\
\text { figures, survey tables }\end{array}$ \\
\hline Konstance L. Moeller & $\begin{array}{l}\text { M.A., Anthropology; } 6 \text { years } \\
\text { experience in archaeological } \\
\text { research and cultural } \\
\text { resources assessment }\end{array}$ & $\begin{array}{l}\text { New World archaeology; } \\
\text { principal author }\end{array}$ \\
\hline Lisa Shogren & $\begin{array}{l}\text { M.A., Anthropology; } 2 \text { years } \\
\text { experience in cultural } \\
\text { resources management }\end{array}$ & $\begin{array}{l}\text { New World ethnography and } \\
\text { archaeology; Sections } 2.4,3.4\end{array}$ \\
\hline Bruce T. Verhaaren & $\begin{array}{l}\text { Ph.D., Archaeology; } 20 \text { years } \\
\text { experience in archaeological } \\
\text { analysis; } 5 \text { years experience } \\
\text { with environmental impact } \\
\text { statements }\end{array}$ & $\begin{array}{l}\text { Settlement archaeology; } \\
\text { Section } 3.5\end{array}$ \\
\hline David A. Walitschek & $\begin{array}{l}\text { M.S., History; } 10 \text { years } \\
\text { experience in archaeological } \\
\text { analysis; } 4 \text { years experience } \\
\text { with environmental impact } \\
\text { statements }\end{array}$ & $\begin{array}{l}\text { North American historic } \\
\text { archaeology; Sections 2.3, } 3.3\end{array}$ \\
\hline Dimis J. Wyman & $\begin{array}{l}\text { M.S., Botany; M.A., Library } \\
\text { Science; } 18 \text { years experience } \\
\text { in technical editing }\end{array}$ & Technical editor \\
\hline
\end{tabular}


APPENDIX:

KNOWN SITE DISTURBANCE WITHIN THE STUDY AREA 
TABLE A.1 Green River: Site Disturbance in Reach 1, Flaming Gorge Dam to the Yampa River Confluence

\begin{tabular}{|c|c|c|c|c|}
\hline Site I.D. ${ }^{a}$ & Prehistoric & Historic & Site Type & Disturbance \\
\hline 42DA6; BLM61 & Yes & $\begin{array}{l}\text { Euro-American } \\
1880-1897\end{array}$ & $\begin{array}{l}\text { Prehistoric lithic } \\
\text { scatter; historic } \\
\text { Dowd's Grave }\end{array}$ & Not specified \\
\hline 42DA30 & Late Prehistoric & No & Architectural & Not specified \\
\hline 42DA40 & Yes & No & Campsite & Water erosion \\
\hline 42DA52 & Yes & No & Campsite & Vandalism \\
\hline 42DA53 & Yes & No & Campsite & Not specified \\
\hline 42DA56 & Yes & No & Campsite & Not specified \\
\hline 42DA59 & Yes & No & Lithic & Not specified \\
\hline 42DA61 & Yes & No & Campsite & Not specified \\
\hline 42DA69 & Yes & No & Lithic workshop & Not specified \\
\hline 42DA166; AS112 & Yes & No & Lithic & Not specified \\
\hline 42DA167; AS113 & No & Yes & Habitation & Looting \\
\hline 42DA168; AS114 & Yes & No & Lithic & Not specified \\
\hline 42DA174; AS124 & Yes & No & Lithic & Not specified \\
\hline 42DA175; AS125 & Yes & No & Lithic & Not specified \\
\hline 42DA196; AS141 & Yes & No & Lithic & $\begin{array}{l}\text { Erosion; inun- } \\
\text { dation; cattle; } \\
\text { jeep trail; } \\
\text { looting }\end{array}$ \\
\hline 42DA202 & Yes & No & Lithic & $\begin{array}{l}\text { Surface dis- } \\
\text { turbance }\end{array}$ \\
\hline 42DA203 & Post-Archaic & No & Campsite & Fence \\
\hline 42DA204 & Yes & No & Lithic & Not specified \\
\hline 42DA211 & No & Yes & $\begin{array}{l}\text { Stone building } \\
\text { foundation }\end{array}$ & Not specified \\
\hline 42DA222; BLM199 & Yes & No & Lithic & Not specified \\
\hline
\end{tabular}


TABLE A.1 (Cont.)

\begin{tabular}{|c|c|c|c|c|}
\hline Site I.D. ${ }^{a}$ & Prehistoric & Historic & Site Type & Disturbance \\
\hline $\begin{array}{l}\text { 42DA223; BLM200; } \\
\text { AS301 }\end{array}$ & Yes & No & Lithic & Not specified \\
\hline $\begin{array}{l}\text { 42DA224; BLM201; } \\
\text { AS302 }\end{array}$ & Yes & No & Lithic & Not specified \\
\hline 42DA226; BLM203 & Yes & No & $\begin{array}{l}\text { Campsite; } \\
\text { rockshelter }\end{array}$ & Not specified \\
\hline 42DA227; BLM205 & No & Yes & $\begin{array}{l}\text { Placer Mining } \\
\text { Operation }\end{array}$ & Not specified \\
\hline 42DA228; BLM216 & Yes & No & Lithic & Not specified \\
\hline 42DA241; BLM219 & Yes & No & Lithic & Not specified \\
\hline 42DA275; BLM202 & Yes & No & Lithic & Not specified \\
\hline 42DA332; BLM206 & Yes & Yes & $\begin{array}{l}\text { Prehistoric lithic } \\
\text { scatter; historic } \\
\text { corral }\end{array}$ & Not specified \\
\hline $\begin{array}{l}\text { 42DA333; BLM207; } \\
\text { AS303 }\end{array}$ & No & Late $1800 \mathrm{~s}$ & $\begin{array}{l}\text { Wagon road and } \\
\text { fence remnant }\end{array}$ & Not specified \\
\hline $\begin{array}{l}\text { 42DA334; BLM208; } \\
\text { AS304 }\end{array}$ & Yes & No & Lithic & Not specified \\
\hline 42DA335; BLM209 & Yes & No & Campsite & Not specified \\
\hline 42DA336; BLM210 & Yes & Yes & $\begin{array}{l}\text { Rockshelter; } \\
\text { historic hearth }\end{array}$ & Not specified \\
\hline 42DA337 & No & Pre-1900 & Saloon & Not specified \\
\hline 42DA338; BLM213 & No & Euro-American & Irrigation canal & Not specified \\
\hline 42DA339; BLM214 & Yes & No & Lithic & Not specified \\
\hline 42DA342 & No & Euro-American & $\begin{array}{l}\text { Bridge and } \\
\text { dugouts }\end{array}$ & Not specified \\
\hline 42DA387 & Yes & No & Lithic & Not specified \\
\hline 42DA388 & Yes & No & Lithic & Not specified \\
\hline 42DA393 & Yes & No & Campsite & Not specified \\
\hline
\end{tabular}


TABLE A.1 (Cont.)

\begin{tabular}{|c|c|c|c|c|}
\hline Site I.D. ${ }^{a}$ & Prehistoric & Historic & Site Type & Disturbance \\
\hline 42DA394 & No & Yes & Irrigation ditch & Not specified \\
\hline 42DA395 & No & Yes & Stagecoach route & Not specified \\
\hline 42DA402 & Yes & No & Campsite & Not specified \\
\hline 42DA409 & Archaic & No & Campsite & Not specified \\
\hline 42DA410 & Yes & No & Lithic & Not specified \\
\hline 42DA411 & Yes & No & Lithic quarry & Not specified \\
\hline 42DA412 & Yes & No & Campsite & Not specified \\
\hline 42DA413 & Yes & No & Lithic & Not specified \\
\hline 42DA414 & Yes & No & Campsite & Not specified \\
\hline 42DA415 & Yes & No & Campsite & Not specified \\
\hline $42 \mathrm{DA} 416$ & Yes & No & Rockshelter & Not specified \\
\hline 42DA417 & Yes & No & Campsite & Not specified \\
\hline 42DA419 & Yes & No & Lithic & Not specified \\
\hline 42DA420 & Post-Archaic & No & Campsite & Not specified \\
\hline 42DA436 & Yes & No & Campsite & Not specified \\
\hline 42DA438 & Yes & No & Campsite & Not specified \\
\hline 42DA485 & Yes & No & $\begin{array}{l}\text { Campsite; lithic } \\
\text { workshop }\end{array}$ & Not specified \\
\hline 42DA486 & Yes & No & Lithic quarry & Not specified \\
\hline 42DA487 & Yes & No & Lithic & Not specified \\
\hline 42DA488 & Fremont & No & $\begin{array}{l}\text { Lithic; ceramic } \\
\text { scatter }\end{array}$ & Not specified \\
\hline $42 \mathrm{DA} 489$ & Late Archaic & No & Lithic & Not specified \\
\hline $\begin{array}{l}\text { 5MF62; } \\
\text { Confluence Site }\end{array}$ & Yes & No & Lithic & Not specified \\
\hline 5MF242 & Yes & No & Lithic & Not specified \\
\hline
\end{tabular}


TABLE A.1 (Cont.)

\begin{tabular}{|c|c|c|c|c|}
\hline Site I.D. ${ }^{a}$ & Prehistoric & Historic & Site Type & Disturbance \\
\hline 5MF248 & Yes & No & Campsite & Not specified \\
\hline 5MF249 & Unknown & Unknown & No data & Not specified \\
\hline $\begin{array}{l}\text { 5MF605; Ft. Davy } \\
\text { Crockett }\end{array}$ & No & 19th century & Fur trading post & River erosion \\
\hline $\begin{array}{l}\text { 5MF688; Metate } \\
\text { Rock }\end{array}$ & Fremont & No & Petroglyphs & Not specified \\
\hline $\begin{array}{l}\text { 5MF840; Flynn } \\
\text { Bottom }\end{array}$ & Yes & No & Habitation & None \\
\hline $\begin{array}{l}\text { 5MF841; Carr } \\
\text { Bottom Site }\end{array}$ & Yes & No & Lithic workshop & River erosion \\
\hline 5MF859 & No & Yes & Round corral & Not specified \\
\hline 5MF1127 & No & Yes & Old Lodore School & Not specified \\
\hline $5 \mathrm{MF} 1228$ & Yes & No & Lithic & Not specified \\
\hline $5 \mathrm{MF} 1229$ & No & Yes & Campsite & Moderate \\
\hline $5 \mathrm{MF} 1230$ & Yes & No & Lithic & Moderate \\
\hline $\begin{array}{l}\text { 5MF1231; Mike } \\
\text { Flynn Cabin }\end{array}$ & No & 19th century & Log cabin & Not specified \\
\hline $\begin{array}{l}\text { 5MF1232; James } \\
\text { Warren Cabin }\end{array}$ & No & 19th century & Log cabin & Not specified \\
\hline $5 \mathrm{MF} 1233$ & No & 19th century & Trash dump & Not specified \\
\hline $5 \mathrm{MF} 1234$ & No & Yes & Architectural & Not specified \\
\hline $\begin{array}{l}\text { 5MF1235; Larry } \\
\text { Curtin Cabin }\end{array}$ & No & Yes & Ranch & Not specified \\
\hline 5MF1236 & No & ca. 1911 & Habitation & Not specified \\
\hline $\begin{array}{l}\text { 5MF1237; Joe } \\
\text { Herrera House }\end{array}$ & No & 19th century & Habitation & Not specified \\
\hline 5MF1238 & Yes & No & Lithic & Road cut \\
\hline 5MF1398 & Unknown & Unknown & No data & Not specified \\
\hline
\end{tabular}


TABLE A.1 (Cont.)

\begin{tabular}{|c|c|c|c|c|}
\hline Site I.D. ${ }^{a}$ & Prehistoric & Historic & Site Type & Disturbance \\
\hline 5MF1752 & Archaic & No & Isolated find & Not specified \\
\hline $\begin{array}{l}\text { 5MF2357; Wade/ } \\
\text { Curtis Cabin }\end{array}$ & No & Yes & $\begin{array}{l}\text { Upper Wade and } \\
\text { Curtis Cabin }\end{array}$ & Relocated \\
\hline 5MF2388 & No & Yes & $\begin{array}{l}\text { U.S. Geological } \\
\text { Survey camp }\end{array}$ & Not specified \\
\hline $\begin{array}{l}\text { 5MF2404; Wade/ } \\
\text { Curtis Cabin }\end{array}$ & No & Yes & $\begin{array}{l}\text { Lower Wade and } \\
\text { Curtis Cabin }\end{array}$ & Not specified \\
\hline 5MF2406 & No & $1890 \mathrm{~s}$ & Outlaw trail & Not specified \\
\hline 5MF2656 & Late Prehistoric & No & Lithic & $\begin{array}{l}\text { Erosion; } \\
\text { possible } \\
\text { vandalism }\end{array}$ \\
\hline 5MF2746 & Yes & No & Campsite & Not specified \\
\hline $\begin{array}{l}\text { BLM288; John } \\
\text { Jarvie Ranch }\end{array}$ & No & $\begin{array}{l}\text { Late 19th, } \\
\text { early } 20 \text { th } \\
\text { century }\end{array}$ & Settlement & Not specified \\
\hline Doc Parson's Cabin & No & Yes & Cabin & Not specified \\
\hline
\end{tabular}

a Site identification numbers are listed by state number (numbered in alphabetical sequence), county code, and county site number - e.g., 42DA6 refers to state 42 (Utah), Daggett County (DA), site 6 in the county; the other county code is MF, Moffat County. For some sites, an additional or alternative site I.D. is presented: AS = Ashley National Forest; BLM = Bureau of Land Management. 
TABLE A.2 Green River: Site Disturbance in Reach 2, Yampa River Confluence to Cub Creek

\begin{tabular}{|c|c|c|c|c|}
\hline Site I.D. ${ }^{a}$ & Prehistoric & Historic & Site Type & Disturbance \\
\hline $\begin{array}{l}\text { 42UN60; } \\
\text { Moonshine Rapids }\end{array}$ & Late Fremont & No & $\begin{array}{l}\text { Cave; rock- } \\
\text { shelter }\end{array}$ & Not specified \\
\hline $42 U N 61$ & Yes & No & Lithic & Not specified \\
\hline $42 \mathrm{UN} 242$ & Yes & No & Campsite & Not specified \\
\hline 42UN253; DNM91 & Yes & No & $\begin{array}{l}\text { Lithic chipping } \\
\text { station }\end{array}$ & Not specified \\
\hline 42UN254; DNM93 & Yes & No & $\begin{array}{l}\text { Lithic chipping } \\
\text { station }\end{array}$ & Not specified \\
\hline 42UN256 & Yes & No & Lithic & Not specified \\
\hline 42UN258; DNM97 & Yes & No & Campsite & Not specified \\
\hline 42UN259; DNM98 & Yes & No & Campsite & Not specified \\
\hline 42UN260; DNM99 & Yes & No & Lithic & Not specified \\
\hline 42UN262; DNM101 & Yes & No & Lithic scatter & Not specified \\
\hline 42UN265; DNM104 & Yes & No & Campsite & Not specified \\
\hline 42UN267; DNM106 & Yes & No & Lithic & Not specified \\
\hline 42UN268; DNM107 & Yes & No & Campsite & Not specified \\
\hline 42UN269; DNM108 & Yes & No & Campsite & Not specified \\
\hline 42UN270; DNM109 & Yes & No & Lithic & Not specified \\
\hline 42UN271; DNM110 & Yes & No & Lithic & Not specified \\
\hline 42UN272; DNM111 & Yes & No & Lithic & Not specified \\
\hline 42UN273; DNM112 & Yes & No & Lithic & Not specified \\
\hline 42UN275; DNM114 & Yes & No & Lithic & Not specified \\
\hline 42UN451 & Fremont & No & Campsite & Not specified \\
\hline $42 \mathrm{UN} 477$ & Yes & No & Lithic & Not specified \\
\hline 42UN478 & Yes & No & Petroglyphs & Not specified \\
\hline
\end{tabular}


TABLE A.2 (Cont.)

\begin{tabular}{|c|c|c|c|c|}
\hline Site I.D. ${ }^{a}$ & Prehistoric & Historic & Site Type & Disturbance \\
\hline 42UN704 & Yes & No & $\begin{array}{l}\text { Lithic; petro- } \\
\text { glyphs }\end{array}$ & Not specified \\
\hline 42UN705 & Yes & No & Lithic & Not specified \\
\hline 42UN706 & Yes & 20th century & Petroglyphs & Not specified \\
\hline 5MF66 & Yes & No & Human burial & Not specified \\
\hline 5MF67 & Fremont & No & Corn shelter & Not specified \\
\hline 5MF70 & Yes & No & Rockshelter & Not specified \\
\hline 5MF86 & Yes & No & Isolated hearth & Not specified \\
\hline 5MF87 & Yes & No & Petroglyphs & Not specified \\
\hline 5MF88 & Yes & No & Petroglyphs & Not specified \\
\hline 5MF89 & Yes & No & Petroglyphs & Not specified \\
\hline 5MF90 & Yes & No & Rockshelter & Not specified \\
\hline 5MF91 & Yes & No & $\begin{array}{l}\text { Rockshelter; } \\
\text { cave }\end{array}$ & Not specified \\
\hline 5MF92 & Yes & No & Rockshelter & Not specified \\
\hline 5MF139 & Yes & No & Lithic & Erosion \\
\hline 5MF140 & Yes & No & Lithic & Not specified \\
\hline 5MF141 & Yes & No & Rock art panel & Not specified \\
\hline $5 \mathrm{MF} 142$ & Yes & No & Lithic & Not specified \\
\hline 5MF156 & Yes & Unknown & Rockshelter & Not specified \\
\hline $5 \mathrm{MF} 157$ & Yes & No & Petroglyphs & Not specified \\
\hline 5MF169 & Yes & No & Lithic & Not specified \\
\hline 5MF170 & Yes & No & Lithic & Not specified \\
\hline 5MF171 & Yes & No & Lithic & Not specified \\
\hline 5MF172 & Yes & No & Lithic & Natural erosion \\
\hline
\end{tabular}


TABLE A.2 (Cont.)

\begin{tabular}{|c|c|c|c|c|}
\hline Site I.D..$^{a}$ & Prehistoric & Historic & Site Type & Disturbance \\
\hline 5MF173 & Yes & No & Lithic & Natural erosion \\
\hline 5MF2119 & Yes & No & Lithic & Not specified \\
\hline 5MF2399 & No & Yes & $\begin{array}{l}\text { Pat Lynch Root } \\
\text { Cellar }\end{array}$ & Not specified \\
\hline $5 \mathrm{MF} 2400$ & No & Yes & $\begin{array}{l}\text { Pat Lynch } \\
\text { Rockshelter }\end{array}$ & Not specified \\
\hline 5MF2406 & No & $1890 \mathrm{~s}$ & Outlaw Trail & Slight disturbance \\
\hline 5MF2407 & No & Yes & $\begin{array}{l}\text { Echo Park } \\
\text { Ranger Station }\end{array}$ & Not specified \\
\hline 5MF2408 & No & Yes & $\begin{array}{l}\text { Pat Lynch Cabin } \\
\text { Site; Chew } \\
\text { Corral }\end{array}$ & Not specified \\
\hline 5MF2652 & Fremont & Historic Ute & Rockshelter & Slight disturbance \\
\hline 5MF2653 & Yes & No & Rockshelter & $\begin{array}{l}\text { Erosion; looting; } \\
\text { vandalism; cattle; } \\
\text { construction }\end{array}$ \\
\hline $\begin{array}{l}\text { 5MF2654; } \\
\text { Whispering Cave }\end{array}$ & Yes & Yes & $\begin{array}{l}\text { Campsite; } \\
\text { rockshelter }\end{array}$ & $\begin{array}{l}\text { Erosion; looting; } \\
\text { vandalism; } \\
\text { construction }\end{array}$ \\
\hline 5MF2655 & Yes & No & Campsite & $\begin{array}{l}\text { Erosion; collec- } \\
\text { tion; possible } \\
\text { vandalism }\end{array}$ \\
\hline
\end{tabular}

a Site identification numbers are listed by state number (numbered in alphabetical sequence), county code, and county site number - e.g., $42 \mathrm{UN} 60$ refers to state 42 (Utah), Uintah County (UN), site 60 in the county; the other county code is MF, Moffat County. For some sites, an additional or alternative site I.D. is presented: DNM = Dinosaur National Monument. 
TABLE A.3 Gunnison River: Site Disturbance in Reach 1, Blue Mesa Reservoir

\begin{tabular}{|c|c|c|c|c|}
\hline Site I.D. ${ }^{a}$ & Prehistoric & Historic & Site Type & Disturbance \\
\hline $5 \mathrm{GN} 1$ & Yes & No & Lithic; stone quarry & Looting \\
\hline 5GN2 & Yes & No & Lithic & None \\
\hline 5GN3 & Yes & No & Lithic & Inundation \\
\hline $5 \mathrm{GN} 4$ & Yes & No & Lithic & Inundation \\
\hline 5GN5 & Yes & No & Lithic & Inundation \\
\hline 5GN6 & Yes & No & Lithic; stone quarry & Inundation \\
\hline $5 \mathrm{GN} 7$ & Possible & Unknown & Rock art & Inundation \\
\hline 5GN8 & Yes & No & Lithic & Not specified \\
\hline 5GN9 & Yes & No & Lithic & Inundation \\
\hline 5GN10 & Multicomponent & No & $\begin{array}{l}\text { Campsite; lithic } \\
\text { workshop }\end{array}$ & Not specified \\
\hline 5 GN14 & Yes & No & Lithic & Disturbance \\
\hline 5 GN50 & Yes & No & Lithic & None \\
\hline 5GN51 & Yes & Possible & Lithic & None \\
\hline 5GN52 & Yes & No & Campsite & $\begin{array}{l}\text { Highway cut; gravel } \\
\text { pit }\end{array}$ \\
\hline 5GN53 & Protohistoric & No & Ute campsite & Erosion \\
\hline 5 GN54 & Yes & No & Lithic & Erosion \\
\hline 5GN55 & Yes & No & Lithic & Ditch \\
\hline 5GN56 & Yes & No & Lithic & None \\
\hline 5GN57 & Yes & No & Lithic & Highway cut \\
\hline 5 GN58 & Yes & No & Lithic & Power line; erosion \\
\hline 5GN59 & Yes & No & Lithic & $\begin{array}{l}\text { Sheet erosion; } \\
\text { irrigation erosion }\end{array}$ \\
\hline 5GN60 & Yes & No & Lithic & None \\
\hline
\end{tabular}


TABLE A.3 (Cont.)

\begin{tabular}{|c|c|c|c|c|}
\hline Site I.D. ${ }^{\mathbf{a}}$ & Prehistoric & Historic & Site Type & Disturbance \\
\hline 5 GN61 & Yes & No & Lithic & None \\
\hline 5 GN62 & Yes & No & Lithic & Slight erosion \\
\hline 5 GN63 & Yes & No & Lithic quarry area & None \\
\hline 5 GN65 & Yes & No & Campsite & Erosion \\
\hline 5 GN66 & Yes & No & Campsite & None \\
\hline 5GN67 & Late Prehistoric & No & Lithic & Erosion \\
\hline $5 \mathrm{GN} 68$ & Yes & No & Lithic & Bulldozer; road cut \\
\hline 5 GN70 & Yes & No & Lithic & None \\
\hline 5 GN71 & Yes & No & Lithic & None \\
\hline 5 GN72 & Yes & No & Lithic & Vandalism; road \\
\hline 5 GN73 & Yes & No & Lithic & Natural erosion \\
\hline 5 GN74 & Yes & No & Lithic & Not specified \\
\hline 5GN75 & Yes & No & Lithic & Not specified \\
\hline 5 GN76 & Yes & No & Lithic & Not specified \\
\hline 5GN129 & Yes & No & Lithic & Natural erosion \\
\hline $5 \mathrm{GN} 130$ & Yes & No & Campsite & Erosion \\
\hline 5GN131 & Yes & No & Campsite & Erosion; road cut \\
\hline 5GN132 & Yes & No & Lithic & Erosion \\
\hline 5GN133 & Yes & No & Campsite & Erosion \\
\hline $5 \mathrm{GN} 134$ & Yes & No & Campsite & Erosion \\
\hline $5 \mathrm{GN} 135$ & Yes & No & Lithic & $\begin{array}{l}\text { Highway cut; fence; } \\
\text { power line; collection }\end{array}$ \\
\hline 5GN136 & Yes & No & Lithic & $\begin{array}{l}\text { Wind erosion; road } \\
\text { cut; collection }\end{array}$ \\
\hline 5GN137 & Yes & No & Campsite & Power line; erosion \\
\hline
\end{tabular}


TABLE A.3 (Cont.)

\begin{tabular}{|c|c|c|c|c|}
\hline Site I.D. ${ }^{a}$ & Prehistoric & Historic & Site Type & Disturbance \\
\hline 5GN138 & Yes & No & Campsite & Erosion \\
\hline 5GN139 & Yes & No & Campsite & Erosion \\
\hline 5GN140 & Yes & No & Campsite & Road cut; collection \\
\hline 5GN141 & Yes & No & Campsite & Erosion \\
\hline $5 \mathrm{GN} 142$ & Yes & No & Campsite & Erosion \\
\hline 5GN143 & Yes & No & Lithic & $\begin{array}{l}\text { Power line; erosion; } \\
\text { collection }\end{array}$ \\
\hline 5 GN145 & Yes & No & Lithic & Livestock \\
\hline 5GN146 & Yes & No & Lithic & None \\
\hline $5 \mathrm{GN} 147$ & Yes & No & Lithic & Erosion \\
\hline $5 \mathrm{GN} 148$ & Yes & No & Lithic & None \\
\hline $5 \mathrm{GN} 149$ & Yes & No & Campsite & None \\
\hline $5 \mathrm{GN} 150$ & Yes & No & Lithic & Erosion \\
\hline $5 \mathrm{GN} 162$ & Yes & No & Lithic & None \\
\hline $5 \mathrm{GN} 163$ & Yes & No & Lithic & None \\
\hline 5GN164 & Yes & No & Campsite & Inundation; road cut \\
\hline $5 \mathrm{GN} 170$ & Yes & Possible & Lithic & Power line \\
\hline 5GN171 & Yes & Possible & Campsite & None \\
\hline 5GN172 & Yes & No & Lithic & None \\
\hline $5 \mathrm{GN} 173$ & Yes & No & Lithic & Erosion \\
\hline $5 \mathrm{GN} 174$ & Yes & Possible & Lithic & None \\
\hline 5GN175 & Yes & No & Campsite & Erosion \\
\hline 5GN176 & Yes & No & Lithic & Erosion \\
\hline 5GN177 & Yes & No & Lithic & Collection \\
\hline
\end{tabular}


TABLE A.3 (Cont.)

\begin{tabular}{|c|c|c|c|c|}
\hline Site I.D. ${ }^{a}$ & Prehistoric & Historic & Site Type & Disturbance \\
\hline 5GN181 & Yes & No & Lithic & Partial inundation \\
\hline $5 \mathrm{GN} 182$ & Yes & No & Lithic & None \\
\hline $5 \mathrm{GN} 183$ & Yes & No & Lithic & Road; power line \\
\hline 5GN184 & Yes & No & Lithic & Erosion \\
\hline 5GN185 & Yes & No & Campsite & $\begin{array}{l}\text { Road cut; erosion; } \\
\text { collection }\end{array}$ \\
\hline 5GN187 & Yes & No & Lithic & None \\
\hline 5GN188 & Yes & No & Lithic & None \\
\hline 5GN189 & Yes & No & Lithic & Partial looting \\
\hline 5GN190 & Yes & No & Lithic & None \\
\hline $\begin{array}{l}\text { 5GN191; Kezar } \\
\text { Basin Site }\end{array}$ & $\begin{array}{l}\text { Paleo-Indian } \\
\text { (Plano); Archaic }\end{array}$ & No & Habitation; campsite & Inundation; erosion \\
\hline 5GN192 & Yes & No & Lithic & Natural erosion \\
\hline 5 GN193 & Yes & No & Lithic & Erosion \\
\hline 5GN196 & Yes & No & Campsite & Partial destruction \\
\hline 5GN198 & Yes & No & Lithic & Collection; erosion \\
\hline 5GN199 & Yes & No & Campsite & None \\
\hline 5GN200 & Yes & No & Campsite & Modern construction \\
\hline 5GN201 & Yes & No & $\begin{array}{l}\text { Campsite; stone } \\
\text { quarry }\end{array}$ & Modern construction \\
\hline 5GN202 & Yes & No & Campsite & Collection \\
\hline 5GN203 & Yes & No & Lithic & Collection \\
\hline 5 GN204/205 & Yes & No & Campsite & $\begin{array}{l}\text { Modern develop- } \\
\text { ment; collection }\end{array}$ \\
\hline 5GN206 & Yes & No & Campsite & Collection \\
\hline 5GN207 & Yes & No & Campsite & Highway cut \\
\hline
\end{tabular}


TABLE A3 (Cont.)

\begin{tabular}{|c|c|c|c|c|}
\hline Site I.D. ${ }^{\mathrm{a}}$ & Prehistoric & Historic & Site Type & Disturbance \\
\hline 5GN208 & Yes & No & Lithic & $\begin{array}{l}\text { Partial inundation; } \\
\text { cut by canal }\end{array}$ \\
\hline 5GN209 & Yes & No & Lithic & Modern trash \\
\hline 5 GN210 & Yes & No & Campsite & Highway cut \\
\hline 5GN211 & Yes & No & Lithic & None \\
\hline 5 GN212 & $\begin{array}{l}\text { Paleo-Indian; } \\
\text { Archaic; Late } \\
\text { Prehistoric }\end{array}$ & No & Habitation; campsite & $\begin{array}{l}\text { Modern develop- } \\
\text { ment; collection }\end{array}$ \\
\hline 5 GN213 & Yes & No & Lithic & None \\
\hline 5GN214 & Yes & No & Lithic & $\begin{array}{l}\text { Road cut; fence; } \\
\text { power line }\end{array}$ \\
\hline 5GN215 & Yes & No & Campsite & Erosion \\
\hline $5 \mathrm{GN} 216$ & Yes & No & Lithic & Highway cut \\
\hline 5GN217 & Yes & No & Campsite & Heavy collection \\
\hline 5GN218 & Yes & No & Lithic & Highway cut \\
\hline 5GN219 & Yes & No & Lithic & Collection; erosion \\
\hline $5 \mathrm{GN} 220$ & Yes & No & Lithic & None \\
\hline $5 \mathrm{GN} 221$ & Yes & Unknown & Campsite & Erosion \\
\hline 5GN222 & Archaic; Ute & Yes & Campsite & $\begin{array}{l}\text { Highway construc- } \\
\text { tion; erosion }\end{array}$ \\
\hline 5 GN223 & Paleo-Indian & No & Campsite & $\begin{array}{l}\text { Collection; partial } \\
\text { destruction }\end{array}$ \\
\hline $5 G N 224$ & Yes & No & Lithic & Erosion \\
\hline $5 \mathrm{GN} 225$ & Yes & No & Campsite & Erosion; collection \\
\hline $5 G N 2 \angle \dot{0}$ & Yes & No & Campsite & Collection; road cut \\
\hline $5 \mathrm{GN} 230$ & Yes & No & Lithic & None \\
\hline 5 GN231 & Yes & No & Lithic & Erosion \\
\hline
\end{tabular}


TABLE A.3 (Cont.)

\begin{tabular}{|c|c|c|c|c|}
\hline Site I.D. ${ }^{a}$ & Prehistoric & Historic & Site Type & Disturbance \\
\hline 5GN247 & $\begin{array}{l}\text { Early; Middle } \\
\text { Archaic }\end{array}$ & No & Campsite & Possible erosion \\
\hline 5GN256 & Yes & No & Architectural & Inundation \\
\hline $5 \mathrm{GN} 257$ & Yes & No & Lithic & Inundation \\
\hline 5GN258 & Yes & No & Campsite & Not specified \\
\hline 5GN259 & Yes & No & Lithic & Inundation \\
\hline $5 \mathrm{GN} 260$ & Yes & No & Lithic & Inundation \\
\hline 5GN283 & Yes & Yes & Architectural & Not specified \\
\hline 5GN284 & Yes & No & Lithic & Not specified \\
\hline 5GN1267 & Yes & No & Isolated find & Not specified \\
\hline $5 \mathrm{GN} 1268$ & Yes & No & Isolated find & Not specified \\
\hline 5GN1665 & Yes & No & Campsite & Not specified \\
\hline 5GN1666 & Late Archaic & No & Lithic & Not specified \\
\hline 5GN1668 & Archaic & No & Lithic & Not specified \\
\hline 5GN1677 & Late Archaic & No & Lithic & Not specified \\
\hline 5GN1686 & Protohistoric & Yes & Lithic & Not specified \\
\hline 5GN1729 & Middle Archaic & No & Architectural & Not specified \\
\hline 5 GN1762 & Yes & No & Lithic; stone quarry & Not specified \\
\hline 5GN1821 & No & Yes & Bridge & Not specified \\
\hline 5GN1822 & No & Yes & Bridge & Not specified \\
\hline $5 \mathrm{GN} 1870$ & Yes & No & Campsite & Collection; erosion \\
\hline 5GN2089 & No & Yes & Settlement & $\begin{array}{l}\text { Demolished; } \\
\text { partially graded }\end{array}$ \\
\hline
\end{tabular}

a Site identification numbers are listed by state number (numbered in alphabetical sequence), county code, and county site number - e.g., 5GN1 refers to state 5 (Colorado), Gunnison County (GN), site 1 in the county. 
TABLE A.4 Gunnison River: Site Disturbance in Reach 2, Blue Mesa Dam to Morrow Point Dam

\begin{tabular}{lllll}
\hline Site I.D. & Prehistoric & Historic & \multicolumn{1}{c}{ Site Type } & \multicolumn{1}{c}{ Disturbance } \\
\hline 5GN20a & Yes & No & Lithic & Downslope erosion \\
5 GN20b & Yes & No & Lithic & Downslope erosion \\
5 GN41 & Protohistoric & No & Campsite & Not specified \\
5 GN64 & Yes & No & Lithic & Erosion; livestock \\
5 GN195 & Yes & No & Lithic & None \\
5 GN255 & Yes & No & Rockshelter & Not specified \\
5 GN265 & Yes & No & Campsite & Not specified \\
5 GN1032 & Yes & No & Isolated find & Not specified \\
5 GN1033 & Yes & No & Isolated find & Not specified \\
5 GN1676 & Archaic & No & Lithic & Not specified \\
5 GN1766 & No & Late 1800s & Curecanti Railroad & Not specified \\
& & & Depot &
\end{tabular}

a Site identification numbers are listed by state number (numbered in alphabetical sequence), county code, and county site number - e.g., 5GN20a refers to state 5 (Colorado), Gunnison County (GN), site 20a in the county. 